Institut für Humangenetik und Institut für Tierzucht und Haustiergenetik der Universität Göttingen

\title{
Expression and Function of Mouse Pelota Gene
}

\author{
Dissertation \\ Zur Erlangung des Doktorgrads \\ Des Fachbereichs Agrarwissenschaften \\ Der Georg-August-Universität zu Göttingen
}

Vorgelegt von

Mahmoud Ahmed Abdel-Hafiez Sallam

aus

Kairo / Ägypten

Göttingen 2001 
D7

Referent:

Prof. Dr. P. Glodek

Korreferent:

Prof. Dr. W. Engel

Tag der mündlichen Prüfung: 


\section{CONTENTS}

Page

ABBREVIATIONS

1 INTRODUCTION

1.1

Cell Cycle

1

1.2

The centrosome

4

1.3

The pelota Gene

5

1.4

Objectives in this work

2 MATERIALS AND METHODS

2.1

Materials

2.1 .1

Chemicals

2.1.2 Solutions and buffers

2.1.3 Sterilization of solutions and equipments

2.1.4

Media, antibiotics and agar-plates

2.1.4.1 Media for bacteria

2.1.4.2 Media for cell culture

2.1 .5

Antibiotics

2.1 .6

IPTG / X-Gal plate

2.1.7

Bacteria strains

2.1.8

Plasmids

2.1 .9

Synthetic oligonucleotide primers

2.1.10 Genomic and cDNA probes

2.1.11 Eukaryotic cell lines

2.1.13.1 Antibodies 
2.2

Methods

Isolation of nucleic acids

2.2.1.1 Isolation of plasmid DNA

2.2.1.1.1 Small-scale isolation of plasmid DNA

2.2.1.1.2 Large-scale isolation of plasmid DNA

2.2.1.1.3 Isolation of DNA fragments after agarose gel electrophoresis

2.2.1.2 Isolation of genomic DNA from tissue samples

2.2.1.3 Isolation of genomic DNA from ES cells

2.2.1.4 Isolation of total RNA from tissue samples and cultured cells

2.2.2 Determination of the nucleic acid concentration

2.2.3.2 Ligation of DNA fragments 23

2.2.3.3 TA-Cloning 23

$\begin{array}{lll}\text { 2.2.3.4 Filling-up reaction } & 24\end{array}$

2.2.4 Gel electrophoresis 24

2.2.4.1 Agarose gel electrophoresis of DNA 24

2.2.4.2 Agarose gel electrophoresis of RNA 24

2.2.5 Preparation of competent E.coli bacteria 25

2.2.6 Transformation of competent bacteria 25

2.2.7 Blotting techniques 26

2.2.7.1 Southern blotting of DNA to nitrocellulose filters 26

2.2.7.2 Northern blotting of RNA onto nitrocellulose filters 26

2.2.8 „Random Prime“ method for generation of ${ }^{32} \mathrm{P}$ labelled DNA 26

2.2.9 Non-radioactive dye terminator cycle sequencing 27

2.2.10 Hybridization of nucleic acids 27

2.2.11 Genotyping of the pelota knockout mice by using PCR 28

2.2.12 Reverse transcriptase PCR (RT-PCR) 28

2.2.13 Histological techniques 30 
2.2.13.1 Tissue preparation for paraffin-embedding 30

2.2.13.2 Sections of the paraffin block 30

2.2.13.3 Staining of the histological sections 31

2.2.13.3.1 Haematoxilin and eosin staining 31

2.2.14 DNA ploidy analysis 31

2.2.15 Feulgen staining (DNA mass) 32

2.2.16 Techniques for production of targeted mutant mice 32

2.2.16.1 Production of targeted embryonic stem cell clones 33

2.2.16.1.1 Preparation of EMFI feeder layers 33

2.2.16.1.2 Growth of ES cells on feeder layer 33

2.2.16.1.3 Electroporation of ES cells 34

2.2.16.1.4 Growing ES cells for Southern blot analysis 34

2.2.16.1.5 DNA isolation from ES cell colonies 34

2.2.17 Production of chimeric mice by the aggregation method 35

2.2.17.1 Recovery of eight-cell stage embryos 35

2.2.17.2 Assembly of ES cell aggregation chimeras 35

2.2.18 Techniques for recovery, culture and genotyping 1.5, 2.5 and 3.5 days old embryos 36

2.2.18.1 Recovery of 1.5 and 2.5 days old embryos 36

2.2.18.2 Recovery of blastocysts $(3.5 \mathrm{dpc}) \quad 36$

2.2.18.3 Culture of the blastocysts and genotyping 36

2.2.19 Chromosomal preparation of embryonic cells 37

2.2.20 Transfection of cells 37

2.2.20.1 Transfection of NIH - 3T3 cells with the GFP-pelota construct 37

2.2.20.2 Transfection of ES cell with the GFP-pelota construct 38

$\begin{array}{lll}2.2 .21 & \text { Immunostaining } & 38\end{array}$ 
3.1.1 Expression of the pelota gene in different tissues of the adult mouse and during prenatal development of the mouse

3.1.2 Expression of mouse pelota gene during testicular development and in the testis of different mutant mice

3.2.2.2 Subcloning of the 3' flanking region of the pelota gene into the pPNT vector

3.2.2.3 Subcloning of the 5' flanking region in the pPNT vector 46

3.2.3 Subcloning of the 5' external probe 46

3.2.4 Electroporation of the RI ES-cells and screening of ES-clones for homologous recombination events

Pelota mutation affects proliferation of inner cell mass of blastocysts in vitro

3.6 Pelota is required for progress of the mitotic cell cycle

3.7.1.1 Transfection of 3T3 fibroblast cell with the $p$ GFP-pelo and subcellular localization of the GFP-fluorescence signal in transfected cells

3.7.1.2 Transfection of the ES cells with the $p G F P$-pelota and selection of stable transfected ES cells 
4 DISCUSSION

4.1 Pelota is highly conserved during evolution

4.2 Expression of the pelota gene during prenatal development and in different mouse tissues

4.3 Mutation of the mammalian pelota gene results in early embryonic lethality

4.4 Mutation of the pelota gene arrests the mitotic division at $\mathrm{G} 2 / \mathrm{M}$ boundary

4.5 Pelota is localized in the centrosomes 


\section{ABBREVIATIONS}

\begin{tabular}{|c|c|}
\hline $\mathrm{BCP}$ & 1-bromo-3-chloropropane \\
\hline BSA & Bovine serum albumin \\
\hline CAS & Cell Analysis System \\
\hline CAT & Chloramphenical acetyltransferase \\
\hline $\mathrm{CBB}$ & Coomasie brilliant blue \\
\hline cdc & Cell division cycle \\
\hline CIN & Chromosome instability \\
\hline Cpm & counts per minutes \\
\hline DEPC & Diethylpyrocarbonate \\
\hline DNA & Deoxyribonucleic acid \\
\hline Dnase & deoxyribonuclease \\
\hline DNTP & deoxynucleotide \\
\hline dpc & Day post coitus \\
\hline DTT & Dithiothreitol \\
\hline $\mathrm{E}$ & Embryo \\
\hline EDTA & Ethylene diamine tetraacetic acid \\
\hline ES & Embryonic stem \\
\hline $\mathrm{F}$ & Forward \\
\hline $\mathrm{F}_{2}$ & Second filial generation \\
\hline $\mathrm{G}$ & Gap-phase \\
\hline g & Gram \\
\hline $\mathrm{hr}$ & Hour(s) \\
\hline IPTG & Isopropyl- $\beta$-thiogalactopyranoside \\
\hline $\mathrm{ICM}$ & Inner cell mass \\
\hline $\mathrm{L}$ & Liter \\
\hline M & Mitosis \\
\hline MPF & Mitosis promoting factor \\
\hline $\mathrm{m}$ & Meter \\
\hline M & Mol \\
\hline MEFs & Mouse embryonic fibroblast cells \\
\hline$\mu$ & Micro \\
\hline
\end{tabular}




\begin{tabular}{|c|c|}
\hline $\min$ & Minute(s) \\
\hline $\mathrm{n}$ & Nano \\
\hline $\mathrm{NaAc}$ & Sodium acetate \\
\hline NBT & Nitro-blue tetrazolium \\
\hline neo & Neomycin \\
\hline NTP & Nucleotide \\
\hline OD & Optimal density \\
\hline $\mathrm{p}$ & Pico \\
\hline PCR & Polymerase chain reaction \\
\hline PMSF & Phenylmethylsulfonyl fuoride \\
\hline QDA & Quantitative DNA analysis \\
\hline $\mathrm{R}$ & Reverse \\
\hline RNA & Ribonucleic acid \\
\hline Rnase & Ribonuclease \\
\hline RT & Room temperature \\
\hline RT-PCR & Reverse transcriptase-PCR \\
\hline $\mathrm{S}$ & Synthesis \\
\hline SDS & Sodium dodecylsulfate \\
\hline $\sec$ & Second(s) \\
\hline SV 40 & Simian Virus 40 \\
\hline TEMED & Tetramethylethylene diamine \\
\hline TGC & Trophoblast gaint cells \\
\hline UV & Ultra violet \\
\hline Vol & Volume \\
\hline X-Gal & 5-bromo-4-chloro-3-indolyl- $\beta$-galactosidase \\
\hline
\end{tabular}

\section{Symbol of amino acids}
A Ala
Alanine
B Asx
Asparagine or Asparatic acid
C Cys
Cysteine
D Asp
Asparatic acid
E Glu
Glutamic acid 


$\begin{array}{lll}\text { F } & \text { Phe } & \text { Phenylalanine } \\ \text { G } & \text { Gly } & \text { Glycine } \\ \text { H } & \text { His } & \text { Histidine } \\ \text { I } & \text { Ile } & \text { Isoleucine } \\ \text { K } & \text { Lys } & \text { Lysine } \\ \text { L } & \text { Leu } & \text { Leucine } \\ \text { M } & \text { Met } & \text { Methionine } \\ \text { N } & \text { Asn } & \text { Asparagine } \\ \text { P } & \text { Pro } & \text { Proline } \\ \text { Q } & \text { Gln } & \text { Glutamine } \\ \text { R } & \text { Arg } & \text { Arginine } \\ \text { S } & \text { Ser } & \text { Serine } \\ \text { T } & \text { Thr } & \text { Threonine } \\ \text { V } & \text { Val } & \text { Valine } \\ \text { W } & \text { Trp } & \text { Tryptophan } \\ \text { Y } & \text { Tyr } & \text { Tyrosine } \\ \text { Z } & \text { Glx } & \text { Glutamine or Glutamic acid }\end{array}$




\section{INTRODUCTION}

\subsection{Cell Cycle}

Two crucial events of the eukaryotic cell cycle are the duplication of chromosomes and their separation from each other. These two processes usually occur in discrete, non-overlapping stages, or phases, of the cell cycle. DNA synthesis occurs in a period called S-phase and chromosomal separation takes place in a subsequent period called M phase. M phase includes two distinct events. (A) Nuclear division (mitosis) by which the duplicated chromosomes are pulled to opposite poles of the cell by a complex apparatus known as the mitotic spindle. (B) Cytoplasm's division (cytokinesis) is a process which gives two new cells, each with its own nucleus and roughly equal cytoplasmatic content. The period between the one $\mathrm{M}$ phase and the initiation of the next cell cycle is called interphase. The cell cycle contains two additional phases: $G_{1}$ phase (Gap phase) occurs before S-phase, while $G_{2}$ phase occurs before $\mathrm{M}$ phase (Figure 1.1). Gap phases serve as important regulatory state of transition, where progression into the next cell-cycle stage is controlled by a variety of intracellular and extracellular signals. These signals can delay cell-cycle progression, for example, when DNA is damaged. The phase $G_{1}$ is a particularly important regulatory state of transition because at that point most cells choose between again division and or return from the cell cycle. Completion of cell cycle requires the coordination of a variety of de novo biosyntheses, assemblies and movements (Hunt and Murray, 1993). During the cell cycle, the chromosomes must be replicated, condensed, segregated, and last of all decondensed. The spindle poles (centrosomes) have to be duplicated, separated and must migrate to opposite poles of the nucleus.

Cells have evolved an intricate defence network to maintain genomic integrity by preventing the induction of permanent damage by endogenous and exogenous mutagens, such as exposure to inhibitors of DNA replication or spindle assembly or to agents that physically damage DNA. The term checkpoint was introduced to describe a mechanism that actively delays a later cell phase until an earlier event is properly completed. For example, when DNA replication is inhibited by hydroxyurea, the cell arrests in early S-phase and does not undergo mitosis. This dependence of mitosis on 
prior completion of DNA replication is due to the action of specific gene products (Weinert et al., 1994). Inactivation of these genes by mutation relieves the cell of this dependence, and such mutants will enter mitosis with incompletely replicated DNA. The genes that establish dependence in the cell cycle constitute checkpoints (Murray, 1992).

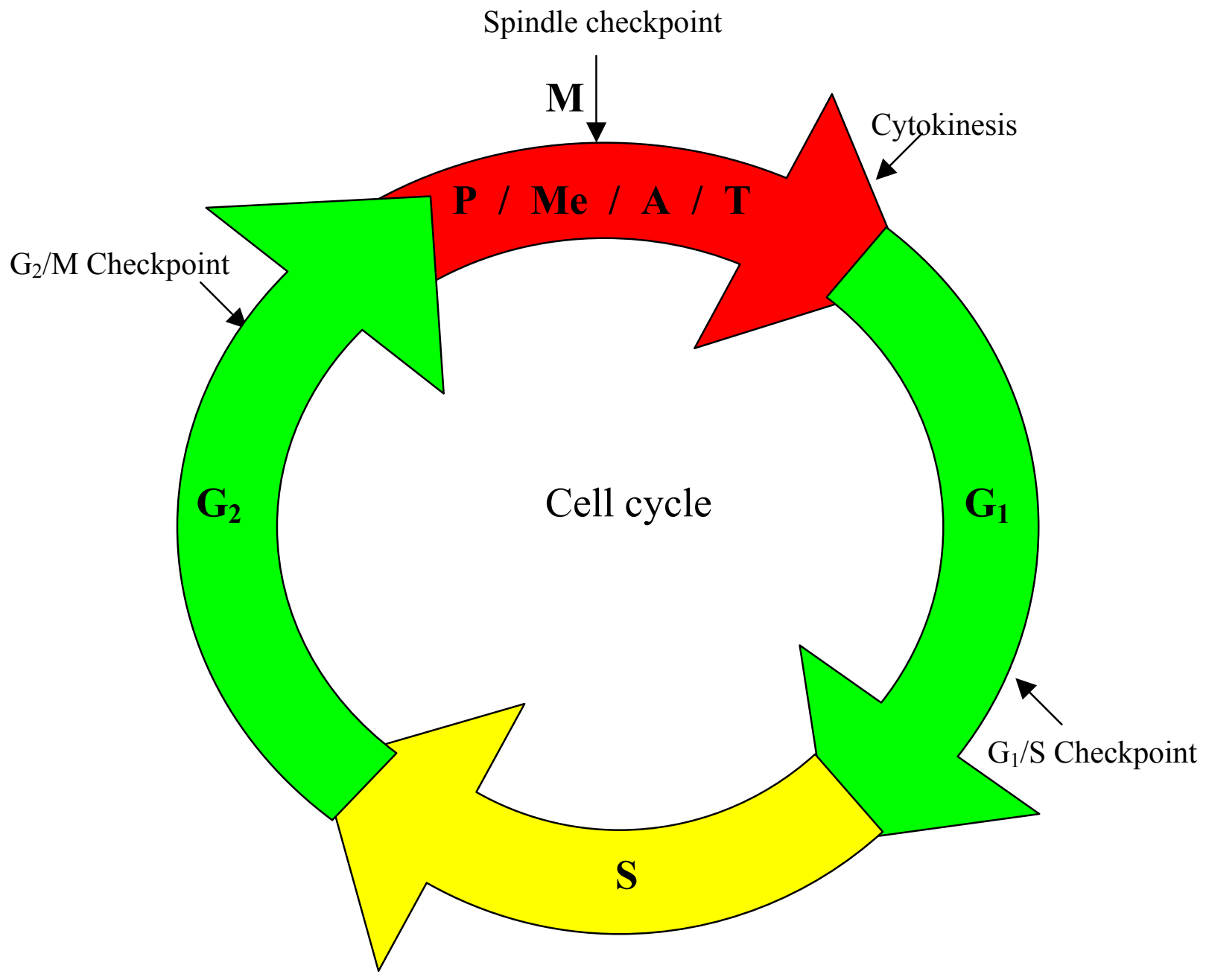

Figure 1.1: Schematic illustration of the cell cycle. Four distinct stages can be distinguished. Gap1 $\left(\mathrm{G}_{1}\right)$ and Gap2 $\left(\mathrm{G}_{2}\right)$ phases control continuous cycle progression via molecular checkpoints $\mathrm{G}_{1} / S$ and $\mathrm{G}_{2} / \mathrm{M}$, whereas $\mathrm{M}$-phase enables chromosomes to segregate by exact codirection of the spindle formation. During S-phase, the reduced DNA content of the cell is resynthesised. 
Loss of checkpoint control results in genomic instability and has been implicated in the transformation of normal cells into cancer cells (Elledge, 1996). There are three major checkpoints controlling the transition of the cell cycle at three points, $\mathrm{G}_{1}-\mathrm{S}, \mathrm{G}_{2}-\mathrm{M}$, and $M-G_{1}$ (Fig. 1.1). The checkpoint controlling the entry into S-phase $\left(G_{1}-S\right)$ prevents the cells from replicating damaged DNA. Cells with DNA damage rapidly increase p53 protein levels by a posttranscriptional mechanism (Kuerbitz et al., 1992). Induction of p53 results in transcriptional activation of p53-dependent genes such as GADD45 (Kastan et al., 1992), MDM2 (Chen et al., 1994). As a direct consequence, the cells either arrest in $G_{1}$ or undergo apoptosis. Unlike wild-type cells, cells defective for p53 proceed to enter the S-phase after irradiation with an increased potential for genomic instability (Livingston et al., 1992). The $\mathrm{G}_{2}-\mathrm{M}$ transition is prevented by DNA damage and by incompletely replicated DNA. A single double-strand break in the DNA will activate this checkpoint and prevent the cell from undergoing mitosis (Fig. 1.1) (Sandell and Zakian, 1993).

Centrosome duplication occurs during the $\mathrm{G}_{2}$-phase. A defect of centrosome duplication stops the completion of mitosis on the $\mathrm{G}_{2}-\mathrm{M}$ checkpoint control. Germ line mutations of the Brcal tumour suppressor gene predisposes women to breast and ovarian cancers. Cytological analysis of mouse embryonic fibroblast cells (MEFs), which carry a targeted mutation in the BRCA1 gene, reveals that the mutant MEFs have an intact $\mathrm{G}_{1}-\mathrm{S}$ checkpoint but a defect in $\mathrm{G}_{2}-\mathrm{M}$ checkpoint. About $25 \%$ of mutant cells also exhibit hyperamplification of functional centrosomes, leading to the formation of multiple spindle poles within a single cell. These abnormalities directly result in the unequal segregation of chromosomes, abnormal nuclear division and aneuploidy (Xu et al., 1999).

One important checkpoint in $M-G_{1}$ transition is the spindle checkpoint. The spindle checkpoint acts in monitoring the assembly of the mitotic spindle and the bipolar attachment of chromosomes to spindle. If microtubule defects are apparent, a signal is generated that leads to a delay of cell cycle progression (Hardwick 1998). Therefore, the spindle checkpoint can detect a multitude of spindle defects, ranging from massive spindle disruption induced by anti-microtubule drugs to the presence of a single unattached kinetochore (Rudner and Murray, 1996). Several proteins have been identified to be components of the spindle checkpoint (e.g. MAD1, MAD2, Bub1 and Bub3 in mammalian cells). These proteins are associated transiently with the kinetochores during mitosis (Chen et al., 1998, Taylor et al., 1998). Cells with 
mutations in the genes encoding these proteins, are unable to arrest in mitosis in response to drug-induced spindle disruption. The absence of this checkpoint allows mouse Mad2-deficient cells to proceed even when unattached chromosomes are present. This leads to missegregated chromosomes and results in aneuploidy (Dobles et al., 2000).

The connections between checkpoints, aneuploidy and cancer have several intriguing factors. In addition to the observations that the vast majority of tumour cells are aneuploid (Kinzler and Vogelstein, 1996), it has recently been shown that cells from human colorectal cancers have a continuous high rate of chromosome loss or gain (giving rise to a chromosome instability CIN) (Lengauer et al., 1997). It has also been shown, that some human lung and colorectal cancers harbour mutations in the spindle assembly checkpoint genes BUB1 and MADI (Cahill et al., 1998; Nomoto et al., 1999). Checkpoint lesions can increase the rate of chromosomal missegregation and have the potential to act as mutations that cause the loss of wild-type tumour suppressor alleles and thereby unravel recessive mutations.

\subsection{The centrosome}

The centrosome is positioned in the centre of interphase cells at the focus of the radial array of microtubules. Microtubules are polymers composed of $\alpha$ - and $\beta$-tubulin subunits, and their synthesis is initiated in the peripheral region of the centrosome by a complex containing the related protein $\gamma$-tubulin (Zheng et al., 1995; Moritz et al., 1995). At the centrosome core a pair of specialized barrel shaped microtubule assemblies, called centrioles, are located. The centrioles and their surrounding pericentrolar matrix define the centrosome as one of the most complex organelles in the cell. The well-characterized function of the centrosomes is to nucleate and organize polarized microtubule arrays that generate cell polarity and to form the structural framework of the meiotic and mitotic spindle.

Yeast cells do not contain centrioles, but exhibit morphologically similar structures called spindle pole bodies. Animal cells lacking centrioles do not form centrosomes (Bobinnec et al., 1998), but can form a bipolar spindle. This alternative spindle assembly pathway is also observed during meiosis of female germ cells (Szollosi et al., 1972). Mouse oocytes and early embryos lack centrioles. In these cells, $\gamma$ - tubulin is 
located at the spindle pole of meiosis II and at mitotic poles in early cleavage stages (Gueth-Hollonet et al., 1993). Centriole-nucleated centrosomes have been found to play a role in regulating cell-cycle progression. Cells from which centrioles have been removed, either by microsurgery or laser ablation, progress through mitosis but arrest in $G_{1}$ of the following cell cycle and never reach S-phase (Hinchcliffe et al., 2001; Khodjakov and Rieder, 2001). The generation of the zygotic centrosome is an intriguing but poorly understood event (Schatten, 1994). In the vast majority of animal species, the centrosome is paternally inherited as the so called sperm basal body. Fertilization leads to conversion of the basal body into a structure fully competent to organize the bipolar spindle of the first embryonic division. Rare exceptions do exist, for instance during mouse development, where centrioles arise de novo after the first few cell divisions (Schatten et al., 1986; 1991).

During mitosis, the centrosomes function as spindle poles, thereby directing the formation of bipolar mitotic spindles and determining the cleavage furrow plane, which are essential for accurate chromosome transmission to daughter cells. Since each daughter cell receives only one centrosome during cytokinesis, it must duplicate prior to the next mitosis, and do so only once. Thus, centrosome duplication must occur in coordination with other cell cycle events, including DNA synthesis. Indeed, duplication of centriols begins close to the $G_{1} / S$ boundary and centrosome duplication is completed in $\mathrm{G}_{2}$ (Vandre and Borisy, 1989; Tournier and Bornens, 1994). Abrogation of the regulation that coordinates centrosome and DNA duplication will likely increase the frequency of centrosome hyperamplification (Brinkley and Goepfert, 1998), which leads to formation of multipolar spindles and unequal segregation of chromosomes to daughter cells (Fukasawa et al., 1996). Recent studies have shown that centrosome hyperamplification is a common phenomena, and is a major factor contributing to chromosome instability in human cancer (Pihan et al., 1998; Lingle et al., 1998; Carroll et al., 1999).

\subsection{The Pelota Gene}

The pelota gene locus was originally identified in a mutagenesis screen of male Drosophila (Castrillon et al., 1993). In homozygous mutant males, the mitotic division occurs normal during spermatogenesis, but the cell cycle of the meiotic division arrests very early in the first meiotic division. Drosophila spermatogenesis begins with the 
generation of spermatogonia from stem cells at the tip of the testis. Each spermatogonium, encased within a cyst of two somatic cells, undergoes four rounds of mitotic division to generate 16 spermatocytes. After a premeiotic $\mathrm{G}_{2}$ phase lasting more than 2 days, two rounds of meiotic division yield a cyst of 64 haploid spermatids. Spermiogenesis, the differentiation of the spermatid, involves development of specialized head and tail structures, followed by sperm individualization. In males homozygous for pelota, the cell cycle arrests either just before or very early in the first meiotic cell division. The apical regions of a testis from a pelota mutant appear normal, filled with progressing growth phase cysts. The caudal part of the testis, which usually contains 64-cell spermatid cysts, is instead filled with 16-cell cysts, while meiotic divisions do not occur in pelota deficient spermatocytes, other aspects of spermatogenesis continue, resulting in $4 \mathrm{~N}$ spermatids.

Further studies investigating the arrest point in meiotic division revealed that the chromosomes in pelota mutant spermatocytes are partially condensed, but never move from the nuclear periphery, the nuclear envelope does not break down and the centrosomes separate but do not complete their migration. A spindle apparatus is never observed in the pelota mutant spermatocytes. These results indicate that the germ line cell cycle is arrested during the meiotic $\mathrm{G}_{2} / \mathrm{M}$ transition phase in pelota male homozygotes (Eberhart and Wasserman, 1995). Beside the effect of the mutation concerning the progression of spermatogenesis, the eyes of pelota homozygotes are up to $30 \%$ smaller than those of heterozygous siblings. These results indicate that pelota is required for Drosophila eye development. The ovaries of pelota homozygous are very small. The mitotic zone of ovaries appear disorganized and often contains degenerating cells. Later stages of oogenesis are also affected. The female mutants produce less than $50 \%$ eggs. These results suggest that the pelota gene is also required for mitotic division in the ovary. Analysis of mitotic and meiotic division in the dom 34 mutants of Saccharomyces cerevisiae, which has a mutation in the pelota orthologous gene, reveals that the mitotic division in dom 34 mutants exhibit a $\mathrm{G}_{1}$ delay, while the meiotic division occurs too rapid and fewer spores are produced compared to wild type. The yeast mutant also fails to segregate chromosomes properly (Davis and Engebrecht, 1998). Introduction of the wild-type pelota transgene into a dom34 mutant provides substantial rescue of the dom 34 growth defects (Eberhart and Wasserman, 1995). The pelota homolog gene has been cloned and sequenced in several species including archaebacteria, Arabidopsis thalania, yeast, Drosophila, C.elegans, mouse and human. 
The encoded protein ranges between 347- 395 amino acids in length. Alignment of the pelota protein sequence reveals that the pelota gene is highly conserved during evolution. The amino acid sequence of archaebacteria, yeast, Drosophila, A. thalania, C. elegans and human protein are $23 \%, 36 \%, 70 \%, 51 \%, 57 \%, 95 \%$ identical to mouse pelota, respectively. All species pelota sequences contain a conserved nuclear localization signal and have acidic domain at the carboxyl end. The human and mouse pelota gene have been isolated and localized on chromosome 5q11 and chromosome 13, respectively (Shamsadin et al., 2000; Shamsadin, unpublished results). Analysis of the expression of the pelota gene demonstrates that the pelota transcript is present in all developmental stages of Drosophila. In human, the pelota mRNA was detected in all analysed tissues (spleen, brain, prostate, testis, ovary, small intestine, colon and leukocytes).

\subsection{Objectives in this work}

The first aim of this work was the characterisation of the expression pattern of the mouse pelota gene during the pre- and postnatal life and during spermatogenesis. Furthermore, the cellular localization of the pelota protein should be analysed.

The second goal was the evaluation of the physiological role of the mammalian pelota gene. For this purpose, mutant mice should be generated carrying a targeted disruption of the endogenous pelota gene. Subsequently, analysis of pelota-deficient mice should reveal functions during embryonic and/or postnatal development, respectively. The phenotype of the pelota deficient mice should be analysed. 


\section{MATERIALS AND METHODS}

\subsection{Materials}

\subsubsection{Chemicals}

All chemicals which are not listed here were obtained from the company Merck, Darmstadt, in p.a. quality.

Acrylamide

Agar

Agarose

Ammonium acetate

Ammonium sulfate

Ampicillin

Bacto-tryptone

Bacto-Yeast-Extract

Bisacrylamide

Blocking powder

Bromophenol blue

BSA

Choloroform

Dextran sulfate

Diethyl pyrocarbonate (DEPC)

Dimethyl sulfoxid (DMSO)

Dithiothreitol

DNA Markers

DNase I (RNase-free)

DNA ligase

dNTPs (100 mM)

Dye Terminator Mix

Ethanol

Ethidium bromide
Serva, Heidelberg

Difco, Detroit, USA

Gibco/BRL, Karlsruhe

Fluka, Neu Ulm

Sigma, Deisenhofen

Sigma, Deisenhofen

Difco, Detroit, USA

Difco, Detroit, USA

Serva, Heidelberg

Boehringer, Mannheim

Sigma, Deisenhofen

Biomol, Hamburg

Baker, Deventer, NL

Amersham, Freiburg

Sigma, Deisenhofen

Merck, Darmstadt

Sigma, Deisenhofen

GibcoBRL, Karlsruhe

Amersham, Freiburg

GibcoBRL, MBI

Boehringer, Mannheim

Applied Biosystems

Baker, Deventer, NL

Sigma, Deisenhofen 
Ficoll 400

FBS

Formaldehyde

Formamide

Geneclean-Kit

Glycerol

Glycine

IPTG

Jetsorb Gel Extraction Kit/300

Kanamycin

Klenow-DNA-Polymerase

Salmon sperms DNA

Lambda DNA

Levamisole

Methyl benzoat

$\beta$-Mercaptoethanol

Mineral oil

Multipriming Kit

Orange G

JETPREP-Plasmid Midi Kit

PBS

Parablast

Picric acid

Phenol

Plasmid-Miniprep Kit

Phagen-Midiprep Kit

Proteinase K

Protein marker

Radioactive substances:

$\left[\alpha^{32} \mathrm{P}\right]-\mathrm{dCTP},\left(\gamma^{32} \mathrm{P}\right)$-dATP

Rediprime $^{\mathrm{TM}}$ II

Restriction enzymes

Reverse Transcriptase

RNase A
Amersham, Freiburg

Gibco/BRL, Karlsruhe

Gibco/BRL, Karlsruhe

Fluka, Neu Ulm

Dianova, Hamburg

Gibco/BRL, Karlsruhe

Biomol, Hamburg

Biomol, Hamburg

Genomed, Bad Oeynhausen

Sigma, Deisenhofen

Amersham, Braunschweig

Sigma, Deisenhofen

Boehringer, Mannheim

Fulka, Neu Ulm

Fulka, Neu Ulm

Serva, Heidelberg

Sigma, Deisenhofen

Amersham, Braunschweig

Sigma, Deisenhofen

Genomed, Bad Oeynhausen

Gibco/BRL, Karlsruhe

Sigma, Deisenhofen

Fulka, Neu Ulm

Gibco/BRL, Eggenstein

Qiagen, Hilden

Qiagen, Hilden

Boehringer, Mannheim

Biorad, Sigma

Amersham, Braunschweig

Amersham, Freiburg

Biolabs, Boehringer, BRL

Gibco/BRL, Eggenstein

Gibco/BRL, Eggenstein 
RNase H

RNase Inhibitor

RNA length standard

RNA Now-Kit

SDS

Select Peptone

Spermidin

T 4 -DNA-Ligase

Taq-DNA-Polymerase

TEMED

Triton X-100

Tris

t-RNA (yeast)

Tween-20

X-Gal

Xylencyanol

Cell culture media
Gibco/BRL, Eggenstein

Boehringer, Mannheim

Gibco/BRL, Eggenstein

TRI Reagent

Serva, Heidelberg

Gibco/BRL, Eggenstein

Sigma, Deisenhofen

Boehringer, Mannheim

Amersham, Braunschweig

Serva, Heidelberg

Serva; Heidelberg

Sigma, Deisenhofen

Boehringer, Mannheim

Sigma, Deisenhofen

Biomol, Hamburg

Bio-Rad, München

Gibco/BRL, Eggenstein;

Sigma, Deisenhofen

\subsubsection{Solutions and buffers}

Ampicillin

Kanamycin

Denaturation solution

Denhardt's solution (50x)
$50 \mu \mathrm{g} / \mathrm{ml} \mathrm{H}_{2} \mathrm{O}$

$50 \mu \mathrm{g} / \mathrm{ml} \mathrm{H}_{2} \mathrm{O}$

$1.5 \mathrm{M} \mathrm{NaCl}$

$0.5 \mathrm{M} \mathrm{NaOH}$

$1 \% \mathrm{BSA}$

1\% Polyvinylpyrrolidon

1\% Ficoll 400

$0.25 \mathrm{M} \mathrm{HCl}$

Depurization solution 
E-buffer (10x)

$300 \mathrm{mM} \mathrm{NaH} 2 \mathrm{PO}_{4}$

$50 \mathrm{mM}$ EDTA

Elution buffer

$1.5 \mathrm{M} \mathrm{NaCl}$

$20 \mathrm{mM}$ Tris- $\mathrm{HCl}$ (pH 7.5)

1 mM EDTA

NBT- Solution

$75 \mathrm{mg} / \mathrm{ml}$

70\% Dimethyl formamide

BCIP-Solution

$50 \mathrm{mg} / \mathrm{ml}$

70\% Dimethyl formamide

Bouin's solution

15 Vol. picric acid (in $\mathrm{dH}_{2} \mathrm{O}$ )

5 Vol. Formaldehyde

1 Vol. Acetic acid

GET-buffer

$50 \mathrm{mM}$ Glucose

10 mM EDTA

25 mM Tris- $\mathrm{HCl}(\mathrm{pH} 8.0)$

Hybridization solution I

5x SSPE solution

5x Denhardt's solution

$0.1 \%$ SDS

Hybridization solution II

$5 x$ SSC

5x Denhardt's solution

$10 \%$ Dextran sulfate

$0.1 \%$ SDS

Kinase buffer (10x)

100 mM Tris- $\mathrm{HCl}$ (pH 7.4)

$100 \mathrm{mM} \mathrm{MgCl} 2$

100 mM DTT 
$1 \mathrm{mM}$ ATP

Ligation buffer (10x)

600 mM Tris- $\mathrm{HCl}(\mathrm{pH} 7.5)$

$80 \mathrm{mM} \mathrm{MgCl}_{2}$

$100 \mathrm{mM}$ DTT

Solution D

4.0 M Guanidinium thiocyanat

$25.0 \mathrm{mM}$ Sodium citrate $(\mathrm{pH} 7.0)$

$0.5 \%$ Sarcosyl

$0.1 \mathrm{M} \beta$-mercaptoethanol

Lysis buffer I

$100 \mathrm{mM}$ Tris-HCl (pH 8.0)

$100 \mathrm{mM} \mathrm{NaCl}$

100 mM EDTA

$0.2 \mathrm{mg} / \mathrm{ml}$ Proteinase K

$0.5 \%$ SDS

Lysis-buffer II

50 mM Tris- $\mathrm{HCl}$ (pH 8.0)

5 mM EDTA

$0.5 \%$ Tween- 20

Neutralization solution

$1.5 \mathrm{M} \mathrm{NaCl}$

$1 \mathrm{M}$ Tris- $\mathrm{HCl}(\mathrm{pH} 7.0)$

PBS buffer

$130 \mathrm{mM} \mathrm{NaCl}$

$7 \mathrm{mM} \mathrm{Na}_{2} \mathrm{HPO}_{4}$

$4 \mathrm{mM} \mathrm{NaH}_{2} \mathrm{HPO}_{4}$

PBT buffer

$0.1 \%$ Tween-20 in PBS (1x)

$\operatorname{SSC}(20 \mathrm{x})$

$3 \mathrm{M} \mathrm{NaCl}$

$0.3 \mathrm{M} \mathrm{Na}_{3}$ citrate (pH 7.0)

SSPE (20x)

0.02 M EDTA 
$0.2 \mathrm{M} \mathrm{NaH}_{2} \mathrm{PO}_{4}$

$3.6 \mathrm{M} \mathrm{NaCl}$

(pH 7.0)

Stop-Mix I

95\% Formamide

$20 \mathrm{mM}$ EDTA

0.05\% Bromphenol blue

$0.05 \%$ Xylen cyanol

Stop-Mix II

15\% Ficoll 400

200 mM EDTA

$0.1 \%$ Orange G

TBE-buffer $(5 \mathrm{x})$

445 mM Tris- $\mathrm{HCl}(\mathrm{pH} 8.0)$

$445 \mathrm{mM}$ Boric acid

$10 \mathrm{mM}$ EDTA

TE-buffer

$10 \mathrm{mM}$ Tris- $\mathrm{HCl}(\mathrm{pH} 8.0)$

$1 \mathrm{mM}$ EDTA

Washing solution I

2x SSC

$0.1 \%$ SDS

Washing solution II

$0.2 \mathrm{x} \mathrm{SSC}$

\subsubsection{Sterilization of solutions and equipments}

All solutions, which are not heat sensitive, were sterilized at $121{ }^{\circ} \mathrm{C}, 10^{5} \mathrm{~Pa}$ for $60 \mathrm{~min}$ in an autoclave (Webeco, Bad Schwartau). Heat sensitive solutions were filtered through a disposable sterile filter ( 0.2 to $0.45 \mu \mathrm{m}$ pore size). Plasticware was autoclaved as above. Glassware was sterilized overnight in an oven at $220^{\circ} \mathrm{C}$. 
2.1.4 Media, antibiotics and agar-plates

\subsubsection{Media for bacteria}

\begin{tabular}{|c|c|}
\hline \multirow[t]{3}{*}{ LB Medium ( $\mathrm{pH} 7.5)$ : } & 1\% Bacto-trypton \\
\hline & $0.5 \%$ Yeast extract \\
\hline & $0.5 \% \mathrm{NaCl}$ \\
\hline \multirow[t]{4}{*}{ LB-Agar: } & 1\% Bacto-trypton \\
\hline & $0.5 \%$ Yeast extract \\
\hline & $0.5 \% \mathrm{NaCl}$ \\
\hline & $1.5 \%$ Agar \\
\hline
\end{tabular}

The LB medium was prepared with distilled water, autoclaved and stored at $4{ }^{\circ} \mathrm{C}$.

\subsubsection{Media for cell culture}

ES-cell medium: DULBECCO's MEM (DMEM)

$\begin{array}{ll}0.1 \mathrm{mM} & \text { Non essential amino acids } \\ 1 \mathrm{mM} & \text { Sodium pyruvate } \\ 10^{-6} \mathrm{M} & \text { B-Mercaptoethanol } \\ 2 \mathrm{mM} & \text { L-Glutamine } \\ 20 \% & \text { Fetal calf serum (FCS) } \\ 1000 \mathrm{U} / \mathrm{ml} & \text { Recombinant leukaemia inhibitory factor (LIF) }\end{array}$


Fibroblast cell medium (EmFi):

$\begin{array}{ll}\text { DULBECCO's MEM (DMEM) } \\ 2 \mathrm{mM} & \text { L-Glutamine } \\ 10 \% & \text { FCS }\end{array}$

M2-medium:

$\begin{array}{ll}5 \mathrm{ml} & (10 \mathrm{x}) \text { Hanks } \\ 1,25 \mathrm{ml} & (40 \mathrm{x}) \text { HEPES } \\ 165 \mathrm{ml} & (300 \mathrm{x}) \text { Sodium pyruvate } \\ 0,25 \mathrm{ml} & 1 \mathrm{M} \mathrm{NaOH} \\ 0,5 \mathrm{ml} & \text { Pencillin }(6 \mathrm{mg} / \mathrm{ml}) / \text { Streptomycin }(5 \mathrm{mg} / \mathrm{ml}) \\ 43 \mathrm{ml} & \mathrm{H}_{2} \mathrm{O} \\ 0,2 \mathrm{~g} & \text { BSA }\end{array}$

M16-medium: $\quad 1 \mathrm{ml} \quad 10 x$ Earle $270 \mu \mathrm{l} \quad 37,5 \times \mathrm{NaHCO}_{3}$

$33 \mu 1 \quad 300 x$ Sodium pyruvate

$100 \mu \mathrm{l} \quad$ Pencillin $(6 \mathrm{mg} / \mathrm{ml})$ Streptomycin $(5 \mathrm{mg} / \mathrm{ml})$

$8,6 \mathrm{ml} \quad \mathrm{H}_{2} \mathrm{O}$

$40 \mathrm{mg} \quad$ BSA

For long time saving of the cells in liquid nitrogen, the following freezing media were used:

$\begin{array}{lll}\text { ES cell - freezing medium: } & 30 \% & \text { ES cell medium } \\ & 50 \% & \text { FCS } \\ & 20 \% & \text { DMSO } \\ \text { EmFi cells - freezing medium: } & 30 \% & \text { EmFi cell medium } \\ & 50 \% & \text { FCS } \\ & 20 \% & \text { DMSO }\end{array}$




\subsubsection{Antibiotics}

Master solutions were prepared for the antibiotics ampicillin and kanamycin, sterile filtered and stored at $-20^{\circ} \mathrm{C}$. The antibiotic needed in each case was added after the autoclaved medium has cooled down to a temperature lower than $55^{\circ} \mathrm{C}$.

$\begin{array}{llll} & \text { Master solution } & \text { solve in } & \text { final concentration } \\ \text { Ampicillin } & 50 \mathrm{mg} / \mathrm{ml} & \mathrm{H}_{2} \mathrm{O} & 50 \mu \mathrm{g} / \mathrm{ml} \\ \text { Kanamycin } & 25 \mathrm{mg} / \mathrm{ml} & \mathrm{H}_{2} \mathrm{O} & 50 \mu \mathrm{g} / \mathrm{ml} \\ \mathrm{G} 418 & 40 \mathrm{mg} / \mathrm{ml} & \mathrm{PBS} & 400 \mu \mathrm{g} / \mathrm{ml}\end{array}$

\subsubsection{IPTG / X-Gal plate}

LB-agar with $50 \mu \mathrm{g} / \mathrm{ml}$ ampicillin, $100 \mu \mathrm{M}$ IPTG and $0.4 \%$ X-Gal was poured into Petri dishes. The dishes were stored at $4^{\circ} \mathrm{C}$.

\subsubsection{Bacteria strains}

E. coli $\mathrm{HB} 101$

Bolivar und Beckmann, 1979

E. coli JM 109

Promega, Wisconsin, USA

E. coli $\mathrm{DH} 5 \alpha$

Hanahan et al., 1985

E. coli TOP 10

Invitrogen, Leek, Niederlande

\subsubsection{Plasmids}

$\begin{array}{ll}\text { pBluesript SK (+/-) } & \text { Stratagene, La Jolla, USA } \\ \text { pGEM-T, pGEM-T Easy } & \text { Promega, Wisconsin, USA } \\ \text { pPNT } & \text { Tybulewicz et al., 1991 } \\ \text { pUC 18 } & \text { Norander et al., 1983 } \\ \text { pZErO-2 } & \text { Invitrogen, Leek, Niederlande } \\ \text { pEGFP-C1 } & \text { Clontech, Heidelberg } \\ \text { pASK-IBA2 } & \text { Institute for Bioanalytic, Göttingen }\end{array}$




\subsubsection{Synthetic oligonucleotide primers}

The synthetic oligonucleotide primers used in this study were obtained either from NAPS (Göttingen, Germany) or Roth (Karlsruhe, Germany) and dissolved in water to a final concentration of $100 \mathrm{pmol} / \mu 1$.

\begin{tabular}{|c|c|}
\hline F3 : & 5‘ GCTGCCAACTTTGGATTCTGG 3‘ \\
\hline F11: & 5' TGAGCCCAGACTGTACGTGAC 3’ \\
\hline F1: & 5‘ TTGCTGAGCCCAGACTGTACG 3‘ \\
\hline F7: & 5' GAGGTCATGAAGCTCGTGAGG 3’ \\
\hline F2: & 5'AGGAAACGGAAAGGCAACTGC 3' \\
\hline F9: & 5' GATTTGGTGGGCAGGACATG 3’ \\
\hline R1: & $5^{\prime}$ TTGACCTGATTGATGTCCTGG 3‘ \\
\hline R2: & 5‘ GTGGAATGCGTGGAATGTACCC 3“ \\
\hline R6: & 5‘ CTGGCTTTGCTCGCTCTTTCC 3‘ \\
\hline R9: & 5‘ GCCCTAGATAAACGTCAAAGG 3“ \\
\hline R10: & $5^{\prime}$ TCCCTGTGTGAGAGAACATGC 3‘ \\
\hline R5: & $5^{\prime}$ CCTGCTTGAGTCCATAGAACG 3’ \\
\hline R4: & $5^{\prime}$ TCGATGGCCTCCACGCAAAGG 3“ \\
\hline R7: & 5' CCGACACATGGAGACTAGAG 3‘ \\
\hline R8: & 5‘ GGCTCCTCGGGGACGAGGGTG 3“ \\
\hline R12: & 5‘ TCTGCACCTTAGCGTGAAGCC 3“ \\
\hline PASK F: & $5^{\prime}$ GGGCCCGGTCTCGGGCCTCATGAAGCTCGTGAGGAAG 3“ \\
\hline PASK R: & 5‘GGGCCCGGTCTCGGCGCTAATTTGAATACATGTCCTGC 3‘ \\
\hline pECFP-C1 F: & $5^{\prime}$ GCGCTCGAGTGAAGCTCGTGAGGAAGAAC 3’ \\
\hline pECFP-C1 R: & 5‘ CCCTCTAGAATTAATCCTCTTCAGAACTGG 3‘ \\
\hline PGK1 R: & $5^{\prime}$ CCATTTGTCACGTCCTGCACG $3^{\prime}$ \\
\hline Poly T: & 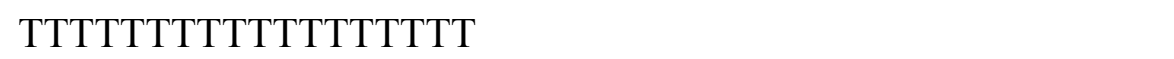 \\
\hline
\end{tabular}

\subsubsection{Genomic and cDNA probes}

$E F-2$ cDNA

Human pelota cDNA
Hanes et al.,1992

Shamsadin et al.,2001 
Mouse pelota cDNA

$6 \mathrm{~kb}$ pBS pelota genomic clone

$9 \mathrm{~kb}$ pGEM pelota genomic clone
Institute of Human Genetics, Göttingen

Institute of Human Genetics, Göttingen

Institute of Human Genetics, Göttingen

\subsubsection{Eucaryotic cell lines}

$3 \mathrm{~T} 3$ fibroblast cells

RI embryonic stem cells (Passage 11), Dr. A. Nagi, Toronto, Canada

\subsubsection{Mouse strains}

Mice strains C57 BL/6J and 129/Sv were ordered from Institute of Human Genetics, Göttingen.

\subsubsection{Antibodies}

Rabbit antiserum against $\gamma$-tubulin and FITS-conjugated goat anti-rabbit antibodies were purchased from Sigma (Deisenhofen) 


\subsection{Methods}

\subsubsection{Isolation of nucleic acids}

\subsubsection{Isolation of plasmid DNA}

\subsection{Small-scale isolation of plasmid DNA}

$5 \mathrm{ml}$ of LB medium with the appropriate antibiotic was inoculated with a single $E$. coli colony and incubated overnight at $37^{\circ} \mathrm{C}$ with shaking. $1.5 \mathrm{ml}$ of this culture was centrifuged at $5000 \mathrm{xg}$ for $10 \mathrm{~min}$. The pellet was resuspended in $200 \mu \mathrm{l}$ of solution P1. After adding equal volumes of solutions P2 and P3, respectively, the pellet was incubated on ice for $15 \mathrm{~min}$, and centrifuged at $13000 \mathrm{xg}$ at $4^{\circ} \mathrm{C}$. The supernatant was transferred into a new tube, and $1 \mathrm{ml}$ of $100 \%$ ethanol was added to precipitate the DNA. It was then stored at $-20^{\circ} \mathrm{C}$ for $30 \mathrm{~min}$, centrifuged at full speed for $30 \mathrm{~min}$, and finally the pellet was dissolved in $30 \mu \mathrm{l}$ of $\mathrm{H}_{2} \mathrm{O}$.

$\begin{array}{lll}\text { P1: } & 50 \mathrm{mM} & \text { Tris-Cl, } \mathrm{pH} 8.0 \\ & 10 \mathrm{mM} & \text { EDTA } \\ & 100 \mu \mathrm{g} / \mathrm{ml} & \text { RNase A } \\ & & \\ \underline{\text { P2: }} & 200 \mathrm{mM} & \mathrm{NaOH}, \\ & 1 \% & \mathrm{SDS} \\ & & \\ \text { P3: } & 3.0 \mathrm{M} & \text { potassium acetate, } \mathrm{pH} 5.5\end{array}$

\subsection{Large-scale isolation of plasmid DNA}

$80 \mathrm{ml}$ LB medium was inoculated with a single $E$. coli colony and incubated overnight at $37^{\circ} \mathrm{C}$ with shaking. The culture was centrifuged at $6000 \mathrm{xg}$ for $10 \mathrm{~min}$. The pellet was resuspended in $4 \mathrm{ml}$ of solution $\mathrm{P} 1$. In order to lyse the cells, $4 \mathrm{ml}$ of solution P2 was added, mixed gently, and incubated for 2-3 min at room temperature. Equal amount of 
solution P3 was added to the tube and mixed immediately by inverting. The mixture was centrifuged at $20000 \mathrm{xg}$ for $30 \mathrm{~min}$ at $20^{\circ} \mathrm{C}$. Meanwhile, the column that was provided by the kit was equilibrated with $10 \mathrm{ml}$ of solution QBT. After centrifugation the lysate was added to the equilibrated column. The column was then washed twice with $10 \mathrm{ml}$ of solution QC. Finally, the DNA was eluted with $5 \mathrm{ml}$ of solution QF. To precipitate the DNA, 0.7 Vol of isopropanol was added and centrifuged at $14000 \mathrm{xg}$ for $30 \mathrm{~min}$ at room temperature. The DNA was dissolved in $100 \mu$ of $\mathrm{H}_{2} \mathrm{O}$.

$\begin{array}{lcl}\text { QBT: } & \begin{array}{c}750 \mathrm{mM} \\ 50 \mathrm{mM}\end{array} & \begin{array}{l}\text { Sodium chloride } \\ \text { MOPS pH 7,0 }\end{array} \\ & 15 \% & \text { Ethanol } \\ & 0,5 \% & \text { Triton X-100 } \\ & & \\ \text { QC: } & 1 \mathrm{mM} & \text { Sodium chloride } \\ & 50 \mathrm{mM} & \text { MOPS pH 7,0 } \\ & 15 \% & \text { Ethanol } \\ & & \\ \text { QF: } & 1,25 \mathrm{M} & \text { Sodium chloride } \\ & 50 \mathrm{mM} & \text { Tris/ HCl pH } 8,5\end{array}$

\subsection{Isolation of DNA fragments after agarose gel electrophoresis}

For the isolation of DNA fragments of 300-4000 bp in length from agarose gels, the Geneclean kit from Biomol 101 (Biomol, Hamburg) was used. The principle of this method depends on the binding capacity of DNA to silica in high salt concentrations and elution in low salt solutions. After separation of DNA on an agarose gel, the DNA fragment to be isolated was excised with a razor blade and weighed. 3 Vol of JETSORB suspension was added to the tube, and the agarose slice was melted at $55^{\circ} \mathrm{C}$. Depending on the DNA amount, required amount of GLASSMILK, which is an aqueous suspension of silica matrix, was added and the tube was placed on ice for $30 \mathrm{~min}$. After centrifuging it at full speed for $2 \mathrm{~min}$, the pellet was washed 2 times with „New Wash“, and allowed to dry at room temperature. To elute the DNA, the pellet was resuspended in $30 \mu \mathrm{lof} \mathrm{H}_{2} \mathrm{O}$ and 
incubated at room temperature for $10 \mathrm{~min}$. After the final centrifugation at $14000 \mathrm{xg}$ for 5 min, the supernatant containing the DNA was transferred into a new tube.

\title{
2.2.1.2 Isolation of genomic DNA from tissue samples
}

Lysis buffer I:

\author{
$100 \mathrm{mM}$ Tris- $\mathrm{HCl}(\mathrm{pH} 8.0)$ \\ $100 \mathrm{mM} \mathrm{NaCl}$ \\ $100 \mathrm{mM}$ EDTA \\ $0.2 \mathrm{mg} / \mathrm{ml}$ Proteinase $\mathrm{K}$ \\ $0.5 \%$ SDS
}

The method employed was the same as that of Laird et al. (1991). 1 to $2 \mathrm{~cm}$ of the tail from a mouse was incubated in $700 \mu \mathrm{l}$ of lysis buffer containing $35 \mu \mathrm{l}$ proteinase $\mathrm{K}(10 \mu \mathrm{g} / \mu \mathrm{l})$ at $55^{\circ} \mathrm{C}$ overnight. Equal volume of phenol was added, mixed by inverting, and centrifuged at $8000 \mathrm{xg}$ at room temperature for $10 \mathrm{~min}$. After transferring the aqueous layer into a new tube, the same procedure was repeated, but this time with $0.5 \mathrm{Vol}$ phenol and $0.5 \mathrm{Vol}$ chloroform. Then, the DNA was precipitated with 2.5 Vol $100 \%$ ethanol, washed with $70 \%$ ethanol, and dissolved in 100-200 $\mu$ of $1 x$ TE buffer.

\subsubsection{Isolation of genomic DNA from ES cells}

Lysis-buffer II:

\author{
$100 \mathrm{mM}$ Tris- $\mathrm{HCl}(\mathrm{pH} 8.5)$ \\ 5 mM EDTA \\ $200 \mathrm{mM} \mathrm{NaCl}$ \\ $100 \mu \mathrm{g} / \mathrm{ml}$ proteinase $\mathrm{K}$ \\ $0.2 \% \operatorname{SDS}$
}

To isolate the DNA from the ES cells, cells were washed with PBS and incubated overnight in $500 \mu \mathrm{l}$ lysis buffer II at $55^{\circ} \mathrm{C}$. Equal volume of isopropanol was added and mixed for 15 min. After washing with $70 \%$ ethanol, DNA was transferred into $60 \mu \mathrm{TE}$ buffer. 


\subsubsection{Isolation of total RNA from tissue samples and cultured cells}

TRI Reagent (Sigme, USA) is an improved version of the single-step method for total RNA isolation. The composition of TRI Reagent includes phenol and guanidine thiocyanate in a mono-phase solution. 100-200 mg tissue sample was homogenized in 1-2 $\mathrm{ml}$ of TRI Reagent by using a glass-teflon homogenizer. The sample volume should not exceed $10 \%$ of the volume of TRI Reagent used for the homogenization. To isolate total RNA from cultured cells, $350 \mu \mathrm{l}$ of TRI Reagent was added to the petri dish $(6 \mathrm{~cm}$ diameter). Cells were homogenized with a rubber stick and the lysate was transferred into an Eppendorf tube. The homogenate was incubated at room temperature for $5 \mathrm{~min}$ to permit the complete dissociation of nucleoprotein complexes. Then, 0.1-0.2 ml of BCP was added which is a less toxic chemical than chloroform, shaked vigorously, and stored at room temperature for $15 \mathrm{~min}$. After centrifugating of the sample at $12000 \mathrm{xg}$ for $15 \mathrm{~min}$ at $4^{\circ} \mathrm{C}$, the colorless upper aqueous phase was transferred into a new tube. The RNA was precipitated by adding $0.5 \mathrm{ml}$ of isopropanol. Finally, the pellet was washed with $75 \%$ ethanol, and dissolved in 80-100 $\mu 1$ DEPC- $\mathrm{H}_{2} \mathrm{O}$.

\subsubsection{Determination of the nucleic acid concentration}

The concentration of nucleic acids was determined photometrically by measuring absorption of the samples at $260 \mathrm{~nm}$. DNA quality i.e. contamination with salt and protein was checked by the measurements at 230, 280, and $320 \mathrm{~nm}$. The concentration was calculated according to the formula:

$$
\begin{aligned}
& \mathrm{C}=(\mathrm{E} 260-\mathrm{E} 320) \times \mathrm{f} \times \mathrm{c} \\
& \mathrm{C}=\text { concentration of sample (ug/ul) } \\
& \text { E } 260=\text { ratio of extinction at } 260 \mathrm{~nm} \\
& \text { E } 320=\text { ratio of extinction at } 320 \mathrm{~nm} \\
& \mathrm{f}=\text { dilution factor } \\
& \text { c = concentration (standard) / absorption (standard) } \\
& \text { for double stranded DNA : } \mathrm{c}=0.05 \mathrm{ug} / \mathrm{ul} \\
& \text { for RNA : } \mathrm{c}=0.04 \mathrm{ug} / \mathrm{ul} \\
& \text { for single stranded DNA : } \mathrm{c}=0.03 \mathrm{ug} / \mathrm{ul}
\end{aligned}
$$




\subsubsection{Enzymatic modifications of DNA}

\subsubsection{Restriction of DNA}

Restriction enzyme digestions were performed by incubating double-stranded DNA with an appropriate amount of restriction enzyme in its respective buffer as recommended by the supplier, and at the optimal temperature for that specific enzyme. Standard digestions include 2-10 U enzyme per microgram of DNA. These reactions were usually incubated for 1-3 $\mathrm{hr}$ to ensure complete digestion at the optimal temperature for enzyme activity, which was typically $37^{\circ} \mathrm{C}$.

\subsubsection{Ligation of DNA fragments}

The ligation of an insert into a vector was carried out in the following reaction mix:

30 ng vector DNA

50-100 ng insert DNA

$1 \mu$ ligation buffer $(10 \mathrm{x})$

$1 \mu \mathrm{l} 44$ DNA ligase $(5 \mathrm{U} / \mu \mathrm{l})$

in a total volume of $10 \mu \mathrm{l}$.

Blunt-end ligations were carried out at $16^{\circ} \mathrm{C}$ overnight, whereas sticky-end ligations were carried out at room temperature for 2-4 hr.

\subsubsection{TA-Cloning}

Taq and other polymerases have a terminal transferase activity which results in the nontemplated addition of a single nucleotide to the 3 '-ends of PCR products. In the presence of all 4 dNTPs, dA is preferentially added. This terminal transferase activity is the basis of the TA- cloning strategy. For cloning of PCR products, the pGEM-T Easy Vector system which has $5^{\prime} \mathrm{T}$ overhangs was employed. The followings were mixed: 


\author{
PCR product ( $3: 1$ vector : insert ratio) \\ $1 \mu 1$ T4 DNA Ligase 10x buffer \\ $1 \mu 1$ T4 DNA Ligase \\ in a total volume of $10 \mu \mathrm{l}$
}

The content was mixed by pipetting and the reaction was incubated overnight at $4^{\circ} \mathrm{C}$. For transformation of the ligation reaction, JM 109 competent cells were used.

\title{
2.2.3.4 Filling-up reaction
}

0.1-4 $\mu \mathrm{g}$ of digested DNA was mixed with $0.05 \mathrm{mM}$ dNTPs and 1-5 $\mathrm{U}$ of Klenow fragment. The reaction was incubated at $37^{\circ} \mathrm{C}$ for $10 \mathrm{~min}$, then stopped by heating at $75^{\circ} \mathrm{C}$ for $10 \mathrm{~min}$.

\subsubsection{Gel electrophoresis}

Gel electrophoresis is the technique by which mixtures of charged macromolecules, especially nucleic acids and proteins, are rapidly separated in an electrical field.

\subsubsection{Agarose gel electrophoresis of DNA}

Agarose gels are used to electrophorese nucleic acid molecules from as small as 150 bases to more than 50 kilobases, depending on the concentration of the agarose and the precise nature of the applied electrical field (constant or pulse). $1 \mathrm{~g}$ of agarose was dissolved in $100 \mathrm{ml} \mathrm{0.5x}$ TBE buffer, and boiled in the microwave, then cooled down to about $50^{\circ} \mathrm{C}$ before adding $3 \mu$ l ethidium bromide $(10 \mathrm{mg} / \mathrm{ml})$. The gel was poured into a horizontal gel chamber.

\subsubsection{Agarose gel electrophoresis of RNA}

Single-stranded RNA molecules often have complementary regions that can form secondary structures. Therefore, RNA was run on a denaturing agarose gel which contained formaldehyde, and additionally was pre-treated with formaldehyde and 
formamide. $1.25 \mathrm{~g}$ of agarose was dissolved in $100 \mathrm{ml}$ of $1 \mathrm{x}$ E-Buffer, after cooling it to about $50^{\circ} \mathrm{C}, 25 \mathrm{ml}$ of formaldehyde $(37 \%)$ was added, stirred and poured into a vertical gel chamber. RNA samples were treated as follows:

10 - $20 \mu \mathrm{g}$ RNA

$2 \mu 110 \times$ E-Buffer

$3 \mu 1$ Formaldehyde

$8 \mu \mathrm{l}$ Formamide (40\%)

$1.5 \mu 1$ Ethidium bromide

Samples were denatured at $65^{\circ} \mathrm{C}$ for $10 \mathrm{~min}$ and chilled on ice before applying to the gel. The gel was run at $80 \mathrm{~V}$ at $4^{\circ} \mathrm{C}$ for about $3-4 \mathrm{hr}$.

\subsubsection{Preparation of competent E.coli bacteria}

Competent bacteria are characterized by a physical cell wall modification which facilitates DNA uptake. LB medium $(100 \mathrm{ml})$ was inoculated with a single colony of E.coli (strain DH5 $\alpha$ ) and the culture was grown at $37^{\circ} \mathrm{C}$ to $\mathrm{OD} 600=0.6$. Bacteria were centrifuged $\left(10 \mathrm{~min}, 4^{\circ} \mathrm{C}, 3000 \mathrm{xg}\right)$ and the pellet was resuspended in $50 \mathrm{ml}$ of sterile $50 \mathrm{mM} \mathrm{Ca} \mathrm{Cl}$ solution $\left(4^{\circ} \mathrm{C}\right)$ and incubated on ice for $30 \mathrm{~min}$. The suspension of bacteria was centrifuged $\left(10 \mathrm{~min}, 4^{\circ} \mathrm{C}, 3000 \mathrm{xg}\right)$ and the pellet was resuspended in 10 $\mathrm{ml}$ of sterile $50 \mathrm{mM} \mathrm{Ca} \mathrm{Cl}_{2}\left(4^{\circ} \mathrm{C}\right)$ with $15 \%$ glycerol. The mixture was dispensed into aliquots of $100 \mu \mathrm{l}$ and stored at $-80^{\circ} \mathrm{C}$.

\subsubsection{Transformation of competent bacteria}

Transformation of the bacteria was done by gently mixing one aliquot of competent bacteria $(50 \mu \mathrm{l})$ with $10 \mu \mathrm{l}$ of ligation reaction. After incubation for $30 \mathrm{~min}$ on ice, bacteria were heated for $45 \mathrm{sec}$ at $42^{\circ} \mathrm{C}$, cooling down for $3 \mathrm{~min}$ on ice. After adding $300 \mu \mathrm{l}$ of $\mathrm{LB}$ medium, bacteria were incubated at $37^{\circ} \mathrm{C}, 200 \mathrm{xg}$ for $1 \mathrm{hr}$ to allow antibiotic resistance expression and were plated out on LB-agar plates containing antibiotic $(50 \mu \mathrm{g} / \mathrm{ml}), 1 \mathrm{mM}$ IPTG and X-Gal 40mg/ml. X-Gal develop "Blue-White" screening 


\subsubsection{Blotting techniques}

\subsubsection{Southern blotting of DNA to nitrocellulose filters}

(Southern, 1975)

In Southern blotting, the transfer of denatured DNA from agarose gels to nitrocellulose membrane is achieved by capillary flow. 20x SSC buffer, in which nucleic acids are highly soluble, is drawn up through the gel into the nitrocellulose membrane, taking with it the single-stranded DNA which becomes immobilized in the membrane matrix. After electrophoresis of DNA, the gel was shaken in $0.25 \mathrm{M} \mathrm{HCl}$ for depurination. It was followed by shaking it further in denaturing solution for $30 \mathrm{~min}$, and $45 \mathrm{~min}$ in neutralizing solution. The transfer of the DNA to the nitrocellulose membrane took place through a Turbo-Blot-apparatus (Schleicher \& Schuell, Dassel). About 26 Whatman filter papers (GB-003) were layed on a Stack Tray followed by 4 Whatman filter papers (GB-002) and 1 Whatman filter paper GB-002 soaked with 20x SSC . The equilibrated nitrocellulose filter which was soaked with 20x SSC was added to the top . The agarose gel was placed on the filter, and was covered with 3 Whatman filter papers GB-002 soaked with 20x SSC. The buffer tray was placed and filled with 20x SSC . Finally the buffer wick which was soaked with 20x SSC, and the wick cover were put on the top of the blot. The transfer was carried out overnight. Finally, after disassembling of the blot, the filter was washed shortly in $2 \mathrm{x}$ SSC and the DNA was fixed onto the filter by either baking it at $80^{\circ} \mathrm{C}$ for $2 \mathrm{hr}$ or by UV-crosslinking ( UV Stratalinker 1800, Stratagene, USA).

\subsubsection{Northern blotting of RNA onto nitrocellulose filters}

For the transfer of RNA onto a nitrocellulose filter, the same procedure as above (2.2.7.1) was performed. In this case, however, the RNA does not need to be denatured, but was transferred directly onto the filter.

\subsection{8 „Random Prime“ method for generation of ${ }^{32} \mathrm{P}$ labelled DNA}

(Feinberg and Vogelstein, 1989)

Ready-To-Go DNA labelling kit (Pharmacia, UK) was employed for labelling of DNA probes. The method depends on the random priming principle developed by Feinberg and 
Vogelstein (1989). The reaction mix contained dATP, dGTP, dTTP, Klenow fragment (4-8 $\mathrm{U})$ and random oligodeoxyribonucleotides. 25-50 ng of DNA were denatured in a total volume of $46 \mu \mathrm{l}$ at $95^{\circ} \mathrm{C}$ for $15 \mathrm{~min}$. After pipetting the denatured probe to Ready-To-Go reaction cup, $4 \mu \mathrm{l}$ of $\left[\alpha_{-}{ }^{32} \mathrm{P}\right] \mathrm{dCTP}(3000 \mathrm{Ci} / \mathrm{mmol})$ was added to the reaction mixture. The labelling reaction was carried out at $37^{\circ} \mathrm{C}$ for $1-3 \mathrm{hr}$.

\subsubsection{Non-radioactive dye terminator cycle sequencing}

Non-radioactive sequencing was performed with the Dye Terminator Cycle SequencingKit (ABI, Weiterstadt). The reaction products were analysed with automatic sequencing equipment, namely 373A DNA Sequencer (ABI, Weiterstadt). For the sequencing reaction, four different dye labelled dideoxy nucleotides were used, which, when exposed to an argon laser, emit fluorescent light which can be detected and interpreted. The reaction was carried out in a total volume of $10 \mu \mathrm{l}$ containing $1 \mu \mathrm{g}$ plasmid DNA or 100-200 ng purified PCR products, 10 pmol primer and $4 \mu \mathrm{l}$ reaction mix (contains dNTPs, dideoxy dye terminators and Taq DNA polymerase). Elongation and chain termination take place during the following program in a thermocycler: $5 \mathrm{~min}$ denaturation followed by 25 cycles at $95^{\circ} \mathrm{C}, 30 \mathrm{sec} ; 55^{\circ} \mathrm{C}, 15 \mathrm{sec}$, annealing; $70^{\circ} \mathrm{C}, 4 \mathrm{~min}$, elongation. After the sequencing reaction, the DNA was precipitated with $1 / 10 \mathrm{Vol} 3 \mathrm{M} \mathrm{NaAc}$ and $2.5 \mathrm{Vol} 100 \%$ ethanol. The pellet was dissolved in $4 \mu \mathrm{l}$ of loading buffer, denatured at $95^{\circ} \mathrm{C}$ for $3 \mathrm{~min}$, and finally loaded onto the sequence gel.

\subsubsection{Hybridization of nucleic acids}

The membrane to be hybridized was equilibrated in $2 \mathrm{x}$ SSC and transferred to a hybridization bottle. After adding $10 \mathrm{ml}$ of hybridization solution, the membrane was incubated for $2 \mathrm{hr}$ in the hybridization oven at an appropriate temperature which was usually $65^{\circ} \mathrm{C}$. Then, the labelled probe and $10 \mu \mathrm{g} / \mu 1$ salmon DNA were denatured at $95^{\circ} \mathrm{C}$ for $10 \mathrm{~min}$ and added to the hybridization solution. The hybridization was carried out overnight in the oven. Next day, the filter was washed for 10 min with $2 x$ SSC at room temperature, then with $2 \mathrm{x}$ SSC and $0.2 \mathrm{x}$ SSC at the hybridization temperature. Finally it was washed with $0.2 \mathrm{x}$ SSC containing $0.1 \%$ SDS at the hybridization temperature. After 
drying the filter, it was sealed in Saran wrap, and exposed to auto radiography overnight at $-80^{\circ} \mathrm{C}$.

\subsubsection{Genotyping of the pelota knockout mice by using PCR}

The genotypes of all offspring of pelota mutant mice were analysed by polymerase chain reaction (PCR). For amplification of the wild-type and the mutant pelota allele, the DNA was extracted from mouse tails as described in 2.2.1.2 and pipetted to the following reaction mixture:

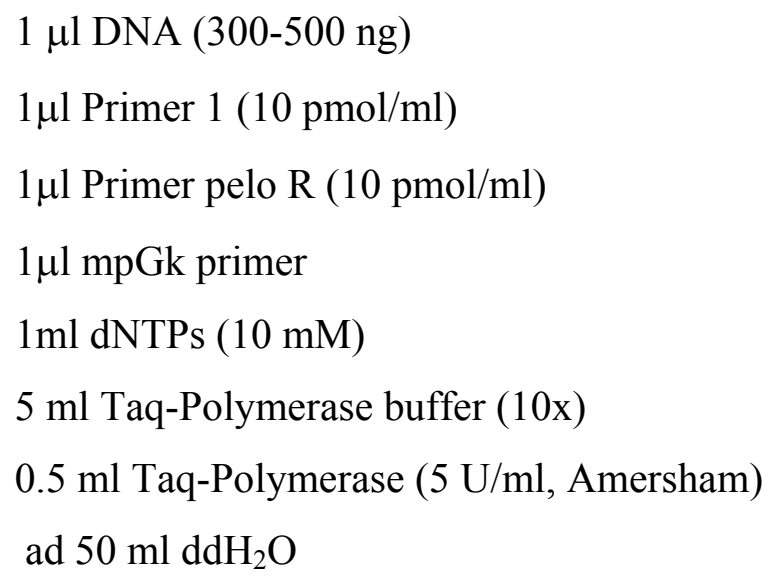

The mixture was covered with mineral oil and the reaction mixture was subjected to the following program in the thermocycler:

$\begin{array}{ll}30 \mathrm{sec} \text { at } 94^{\circ} \mathrm{C} & \text { Denaturation } \\ 60 \mathrm{sec} \text { at } 60^{\circ} \mathrm{C} & \text { Annealing } \\ 60 \mathrm{sec} \text { at } 72^{\circ} \mathrm{C} & \text { Elongation }\end{array}$

Before beginning of the first cycle, DNA template was denatured for 4 min at $95^{\circ} \mathrm{C}$.

\subsubsection{Reverse transcriptase PCR (RT-PCR)}

Total RNA $(1-5 \mu \mathrm{g})$ was mixed with $1 \mu \mathrm{l}$ of oligo $(\mathrm{dT})_{18}$ primer $(10 \mathrm{pmol} / \mu \mathrm{l})$ in a total volume of $11 \mu \mathrm{l}$. To disrupt the secondary structure of the RNA, which might interfere 
with the cDNA synthesis, the mixture was heated at $70^{\circ} \mathrm{C}$ for $10 \mathrm{~min}$, and then quickly chilled on ice. After a brief centrifugation, the following components were added to the mixture:

$$
\begin{aligned}
& 4 \mu 15 \text { x First Strand buffer } \\
& 2 \mu 10.1 \text { M DTT } \\
& 1 \mu 110 \mathrm{mM} \text { dNTPs } \\
& 1 \mu 1 \text { Rnasin }(10 \mathrm{U} / \mathrm{ul})
\end{aligned}
$$

The content of the tube was mixed gently and incubated at $42^{\circ} \mathrm{C}$ for $2 \mathrm{~min}$. Then $1 \mu \mathrm{lof}$ reverse transcriptase enzyme (SUPERSCRIPT II RNase H-Reverse Transcriptase, GibcoBRL Life Technologies, USA) was added, and further incubated at the same temperature for $1 \mathrm{hr}$. The reaction was inactivated by heating at $70^{\circ} \mathrm{C}$ for $15 \mathrm{~min} .10 \%$ of the first strand cDNA reaction was used for the PCR reaction.

$10 \mu 110$ x PCR buffer

$3 \mu 150 \mathrm{mM} \mathrm{KCl}$

$2 \mu 10 \mathrm{mM}$ dNTP mix

$1 \mu \mathrm{l}$ primer $1(10 \mathrm{pmol} / \mathrm{ul})$

$1 \mu 1$ primer $2(10 \mathrm{pmol} / \mathrm{ul})$

$1 \mu \mathrm{l}$ Taq DNA polymerase (5 U/ul)

$2 \mu \mathrm{l}$ cDNA (from first strand reaction)

$80 \mu \mathrm{H}_{2} \mathrm{O}$

The reaction was first heated to $94^{\circ} \mathrm{C}$ for 3 min and then subjected for 35 cycles of PCR amplification. 


\subsubsection{Histological techniques}

\subsubsection{Tissue preparation for paraffin-embedding}

Bouin's Solution

$15 \mathrm{ml}$ Picric acid

$5 \mathrm{ml} \mathrm{37 \%}$ Formaldehyde

$1 \mathrm{ml}$ Acetic acid

The freshly prepared embryos were fixed in Bouin's solution for $24 \mathrm{hr}$ to prevent the alterations in the cellular structure. The tissue to be embedded in paraffin should be free of water. The dehydration process was accomplished by passing the tissue through a series of increasing alcohol concentrations. For this purpose, the tissue was let in 30\%, 70\%, 90\%, and $100 \%(2 \mathrm{x})$ ethanol for $1 \mathrm{hr}$ at room temperature. Later, the alcohol was removed from the tissue by incubating it in methylbenzoat overnight. It was then incubated in $5 \mathrm{ml}$ of histoclear (Xylol) for 10-30 $\mathrm{min}$ at room temperature. The second histoclear was not discarded but $5 \mathrm{ml}$ of paraplast was added and the incubation was continued at $60^{\circ} \mathrm{C}$ for another $30 \mathrm{~min}$. The histoclear and paraffin mixture was discarded, and the tissue was further incubated in $5 \mathrm{ml}$ of paraplast at $60^{\circ} \mathrm{C}$ overnight. Before embedding, the paraffin was changed at least three times. Finally, the tissue was placed in embedding mold and melted paraffin was poured into the mold to form a block. The block was allowed to cool and was then ready for sectioning.

\subsubsection{Sections of the paraffin block}

The paraffin blocks were pre-cut to the optimal size and clamped into the microtom ( $\mathrm{Hn} 40$ Ing., Nut hole, Germany). The cut-thickness of the paraffin embedded was for $7 \mu \mathrm{m}$. The sections were floated on $40^{\circ} \mathrm{C}$ water to allow actual spread and subsequently put onto pretreated slides. In order to achieve a better adhesion of the sections, the slides were treated with a drop of serum-formalin. A fine brush was used to transfer the sections to the pretreated slides. After complete evaporation at $37^{\circ} \mathrm{C}$ for $2-5$ days, slides were stored at $4^{\circ} \mathrm{C}$ for further analysis.

Serum-Formalin:

$15 \mathrm{ml}$

Fresh serum 


$\begin{array}{ll}15 \mathrm{ml} & \text { Glycerin } \\ 6 \mathrm{ml} & \text { Formalin6\% }\end{array}$

\subsubsection{Staining of the histological sections}

\subsection{Haematoxilin and eosin staining}

The stored slides with the paraffin sections were stained by the following method:

1. Slides were incubated three time in histoclear (Xylol) for $3 \mathrm{~min}$.

2. Incubation in $100 \%, 96 \%, 80 \%, 70 \%$ and $50 \%$ ethanol for $2 \mathrm{~min}$.

3. $1 \mathrm{~min}$ in $\mathrm{dH}_{2} \mathrm{O}$ and then $7 \mathrm{~min}$ in haematoxilin Harris.

4. Running tap water (control) for $10 \mathrm{~min}$, then $1 \mathrm{~min}$ in $\mathrm{dH}_{2} \mathrm{O}$.

5. Eosin $0.1 \%+2$ drops acetic acid for $5 \mathrm{~min}$, then in $\mathrm{dH}_{2} \mathrm{O}$ for $1 \mathrm{~min}$.

6. Incubation in 50\%, 70\%, 80\%, 90\%, 96\% and 100\% ethanol for $2 \mathrm{~min}$.

7. Slides were incubated two time in histoclear (Xylol) for $3 \mathrm{~min}$.

\subsubsection{DNA ploidy analysis.}

To determine the DNA content in cell of cultured blastocysts, blastocysts were recovered from uteri of heterozygous females mated with heterozygous males, cultured separately as described in 2.2.18.3. After two days in culture, cells were trypsinized and spread onto glass slides, fixed in acetone at $-20^{\circ} \mathrm{C}$ and quantitatively stained for DNA content by the Feulgen reaction using manufacturer's protocols (Becton Dickinson, Hamburg). Quantitative DNA analysis (QDA) was performed by the cell analysis system (CAS-200) image. Calibration was performed by using the mouse leukocytes. For DNA content in cells of embryos at E7.5, histological sections of embryos were prepared. Cells of the embryo were marked under microscope before CAS image analysis. 


\subsubsection{Feulgen staining (DNA mass)}

Paraffin sections were incubated in $5 \mathrm{~N} \mathrm{HCl}$ for $60 \mathrm{~min}$ and then in the Feulgen staining solution for $1 \mathrm{hr}$ (CAS DNA staining kit by Cell Analysis System, Becton Dickinson, Hamburg). Afterwards, slides were rinsed in acid alcohol, cleaned in xylene and covered using synthetic medium. Mouse leucocytes stained with Feulgen were used as control cells. Slides prepared in this way were evaluated using CAS-200 image analyser (Becton Dickinson, Hamburg) and the quantitative DNA analysis (QDA) software package. DNA content was quantified by assigning an optical density to each pixel of an image and summing the optical density values for each nucleus. The image system was calibrated by measuring the DNA content of mouse leucocytes. For ploidy analysis 100-200 cells were measured. The following parameters were evaluated:

(A) Percentage of diploid cells (DNA index 0.83-1.22)

(B) Percentage of aneuploid cells between 2c and 4c (DNA index 1.22-1.83)

(C) Percentage of tetraploid cells (DNA index 1.83-2.22)

(D) Percentage of aneuploid cells between 4c and 8c (DNA index 2.22-3.84)

(E) Percentage of octaploid cells (DNA index 3.84-4.23)

(F) Percentage of 16-ploid cells (DNA index 7.90-8.23)

(ER) Exceeding rate defined as the percentage of cells with the DNA content higher than $5 \mathrm{C}$.

\subsubsection{Techniques for production of targeted mutant mice}

The discovery that cloned DNA introduced into tissue culture cells can undergo homologous recombination at specific loci has revolutionized our ability to study gene function in vitro and in vivo. In theory, this techniqe will allow us to generate any type of mutation in any cloned gene. Over twenty years ago, pluripotent mouse embryonic stem cells (ES) derived from inner cell mass cells of mouse blastocysts were isolated and cultured (Martin, 1981; Evans and Kaufman, 1981). Using stringent culture conditions, these cells can maintain their pluripotent developmental potential even after many passages and following genetic manipulations. Genetic alterations introduced into ES cells in this way can be transmitted into the germline by producing mouse chimeras. Therefore, 
applying gene targeting technology to ES cells in culture can give the apportunity to alter and modify endogenous genes and study their functions in vivo.

\subsubsection{Production of targeted embryonic stem cell clones}

\subsection{Preparation of EMFI feeder layers}

A frozen vial of EMFI cell was quickly thawed at $37^{\circ} \mathrm{C}$ and transferred to $10 \mathrm{ml}$ EMFI medium. After centrifugation at $270 \mathrm{xg}$ for $5 \mathrm{~min}$, the cell pellet was gently resuspended in $10 \mathrm{ml}$ EMFI medium. Cells were incubated at $37^{\circ} \mathrm{C}, 5 \% \mathrm{CO}_{2}$. When the cells formed a confluent monolayer (three days), they were either trypisinized, transferred to five 150 $\mathrm{mm}$ dishes and grown until they formed confluend monolayers, or directly treated with mitomycin C. To treat the EMFI with mitomycin $\mathrm{C}$, the medium was removed and $10 \mathrm{ml}$ fresh medium containing $100 \mu$ mitomycin $\mathrm{C}(1 \mathrm{mg} / \mathrm{ml})$ was added. After $2-3 \mathrm{hr}$ of incubation, the monolayer of cells was washed twice with $10 \mathrm{ml}$ PBS. The cells were then resuspended with $10 \mathrm{ml}$ medium and any cell aggregates were dissolved by gently pipetting. The cells were centrifuged, resuspended in EMFI medium and plated onto dishes, which were treated with $0.1 \%$ gelatine for $30 \mathrm{~min}$. The feeder cells were allowed to attach by incubation overnight at $37^{\circ} \mathrm{C}, 5 \% \mathrm{CO}_{2}$ or used after $2 \mathrm{hr}$ of incubation. Before adding ES cells on the feeder layer, the medium was changed to ES cell medium.

\subsection{Growth of ES cells on feeder layer}

One vial of frozen ES cells was quickly thawed and cells were transferred to a $12 \mathrm{ml}$ tube containing $6 \mathrm{ml}$ ES cell medium. After centrifugation, the cell pellet was resuspended in 5 $\mathrm{ml}$ ES cell medium and plated on $60 \mathrm{~mm}$ dishes containing EMFIs. The medium was changed the next day. The second day, cells were washed with PBS, treated with $2 \mathrm{ml}$ trypsin/EDTA at $37^{\circ} \mathrm{C}, 5 \% \mathrm{CO}_{2}$ for $5 \mathrm{~min}$. The cells were gently pipetted up and down to dissolve cell clumps, resuspended with $5 \mathrm{ml}$ ES medium and centrifuged. The cell pellet was resuspended in $10 \mathrm{ml}$ ES cell medium and distributed either to 5 or 6 dishes $(60 \mathrm{~mm})$, containing feeder layers or to 2 dishes $(100 \mathrm{~mm})$ containing feeder layers. The medium was changed the next day, and the cells were passaged every second day as described above. 


\subsection{Electroporation of ES cells}

ES cells which have grown for two days on $100 \mathrm{~mm}$ dishes were trypsinized. The cell pellet was resuspended in $20 \mathrm{ml}$ PBS and centrifuged.The cell pellet was then resuspended in $1 \mathrm{ml}$ PBS. $0.8 \mathrm{ml}$ of cell suspension was mixed with $40 \mu \mathrm{g}$ of linearized DNA-construct and transferred into an electroporation cuvette. The electroporation was performed at 240 $\mathrm{V}, 500 \mu \mathrm{F}$ with the BIO RAD gene pulser ${ }^{\mathrm{TM}}$ (BIORAD, USA). After electroporation, the cuvette was placed on ice for $20 \mathrm{~min}$. The cell suspension was transferred from cuvette into $20 \mathrm{ml}$ of ES cell medium and plated onto two $100 \mathrm{~mm}$ dishes containing feeder layers. The medium was changed the next day. Two days after the electroporation, the drugs for the selection were added (active G418 at 150-250 $\mu \mathrm{g} / \mathrm{ml}$, and gancyclovir at $2 \mu \mathrm{M}$ ). The medium was changed every day. After about eight days of selection, drug resistant colonies have appeared and were ready for screening by Southern blot analysis.

\subsection{Growing ES cells for Southern blot analysis}

The drug resistant colonies that were formed after about eight days of selection were picked with a drawn-out Pasteur pipette under a dissecting microscope. Each colony was transferred into a 24 well plate containing feeders and ES cell medium. After 2 days, the ES cells were trypsinized with $100 \mu$ trypsin for 5 min and resuspended in $500 \mu \mathrm{ES}$ cell medium. Half of the cell suspension in each well was transferred to a well on two different 24 well plates, one gelatinised plate, and the other containing feeder cells (master plate). The gelatinised plate was used for preparing DNA and the master plate was kept frozen.

\subsection{DNA isolation from ES cell colonies}

The medium from each well on the gelatinised plate was aspirated. The wells were washed with PBS. Lysis buffer $(500 \mu \mathrm{l})$ was added to each well in the gelatinised plate and the plate was incubated overnight at $37^{\circ} \mathrm{C}$. To each well, $500 \mu \mathrm{l}$ isopropanol was added and the suspension was shaked for approximately $15 \mathrm{~min}$, until precipitated DNA become visible. The DNA pellet was then washed with $500 \mu \mathrm{l}$ of $70 \%$ ethanol for $5 \mathrm{~min}$, transferred into 
an Eppendorf cup containing $50 \mathrm{ul}$ of $1 \mathrm{x}$ TE buffer and incubated for $30 \mathrm{~min}$ at $60^{\circ} \mathrm{C}$ to evaporate remaining ethanol.

\subsubsection{Production of chimeric mice by the aggregation method}

\subsubsection{Recovery of eight-cell stage embryos}

Pregnant females were killed on the third day of pregnancy (2.5 day post-coitus) by cervical dislocation. The skin and peritoneum were opened with a large transverse incision to expose the abdominal cavity. The oviducts with the upper part of the uterus were dissected and placed into a drop of M2 medium. Under dissecting microscope, the needle attached to a $1 \mathrm{ml}$ syringe was inserted in the fimbrial end of the oviduct. The needle was then holded with the forceps and the oviducts were flushed with $0.05 \mathrm{ml}$ of M2 medium. Embryos were collected with a mouth pipette and washed through several M2 drops. To remove the zona pellucida, embryos were treated in one drop of Tyrode's acid and then transferred into the drop of M16 as soon as their zona dissolved. The embryos were washed through two to three drops of M16 before transferring them into the aggregation plate.

\subsubsection{Assembly of ES cell aggregation chimeras}

To prepare the ES cells for the aggregation, a plate with ES cells was rinsed with $3 \mathrm{ml}$ of trypsin. The cells were incubated for $5 \mathrm{~min}$ at $37^{\circ} \mathrm{C}$ until they formed clumps of loosely connected cells, then $5 \mathrm{ml}$ of ES medium was added. Under the dissecting microscope a number of clumps of loosely connected cells were transferred to a drop containing embryos in the aggregation plate. Several drops of M16 were pipetted in the aggregation plate and covered with mineral oil. In each drop, five small depressions were made in the plastic with a darning needle that serve as cradles for the aggregation. The walls of the depression bring the embryos and ES cells into close proximity and therefore promote their aggregation. To assemble the aggregation, one clump of ES-cells (usually 10-15 cells) was transferred to a depression containing embryo. The aggregation plate was incubated overnight at $37^{\circ} \mathrm{C}$ and $5 \% \mathrm{CO}_{2}$. Usually more than $90 \%$ of ES-morulae 
aggregated overnight to form early blastocysts. These blastocysts were collected from the depressions and transferred directly into the uterus of pseudopregnant females.

\subsubsection{Techniques for recovery, culture and genotyping 1.5, 2.5 and 3.5 days old embryos}

\subsubsection{Recovery of 1.5 and 2.5 days old embryos}

1.5 and 2.5 days old embryos are present in the oviduct 30-60 h post coitus (pc). By this time, the embryos have lost their cumulus cells and they can be flushed from the oviduct. To isolate the 1.5 and 2.5 days old embryos, pregnant mice (1.5 and 2.5 days pc) were killed by cervical dislocation. The dissection of the oviducts and recovery of embryos was done as described before (2.2.17.1). The collected embryos were washed five times in a drop of PBS and each single embryo was transferred into an Eppendorf tube containing $5 \mu \mathrm{l}$ PBS.

\subsubsection{Recovery of blastocysts (3.5 dpc)}

Blastocysts can be flushed easily from the uterus between 3.5 and 4.5 days (pc). On the fourth day of pregnancy (3.5 days pc) mice were killed by cervical dislocation. The skin and peritoneum were opened with a large transverse incision to expose the abdominal cavity. The uterus was grasped with a forceps above the cervix and cut with fine scissors. Then, the uterus was cut below the junction to the oviduct, placed into M2-medium and both horns were flushed with about $0.2 \mathrm{ml}$ of M2-medium. The collected blastocysts were washed five times in a drop of PBS. Single blastocysts were transferred into an Eppendorf tube containing $5 \mu 1 \mathrm{H}_{2} \mathrm{O}$ and genotyped by PCR.

\subsubsection{Culture of the blastocysts and genotyping}

The collected blastocysts were washed five time in drops of PBS and then transferred into a well of a 96-well plate containing $20 \mu \mathrm{l}$ of ES medium. The 96-well plate was incubated at $37^{\circ} \mathrm{C}, 5 \% \mathrm{CO}_{2}$ for five days. Cultured embryos were washed twice with PBS and 
incubated with $20 \mu \mathrm{l}$ lysis buffer for $5 \mathrm{hr}$ at $37^{\circ} \mathrm{C}$. The embryonic extract was transferred into an Eppendorf tube and boiled for 5 min. $5 \mu$ of the extract were used for the PCRassay.

\subsubsection{Chromosomal preparation of embryonic cells}

After culturing of blastocyst for 48-72 hr, $3 \mu 1$ Nocodazol $(1 \mu \mathrm{g} / \mathrm{ml})$ was added to $30 \mu \mathrm{l}$ of culture medium and cells were further incubated for $6 \mathrm{hr}$ at $37^{\circ} \mathrm{C}, 5 \% \mathrm{CO}_{2}$. Cells were washed twice with PBS, trypsinized with $30 \mu \mathrm{l}$ trypsin and incubated at $37^{\circ} \mathrm{C}, 5 \% \mathrm{CO}_{2}$ for 5 min. Trypsin was inactivated with $150 \mu$ of ES cell medium. Cells were resuspended two times with a micropipette, transferred in an Eppendorf tube and centrifuged at $250 \mathrm{xg}$ for $5 \mathrm{~min}$. After resuspension in $100 \mu \mathrm{l}$ of $75 \mathrm{mM} \mathrm{KCl}(0.563 \%)$ cells were incubated for $20 \mathrm{~min}$ at $37^{\circ} \mathrm{C}$ and centrifuged at $500 \mathrm{xg}$ for $5 \mathrm{~min}$. After removing of the $\mathrm{KCl}$, cells were fixed in $100 \mu \mathrm{l}$ ice cold methanol/acetic acid $3: 1(\mathrm{Vol} / \mathrm{Vol})$ for $10 \mathrm{~min}$ at $4^{\circ} \mathrm{C}$ and centrifuged at $650 \mathrm{xg}$ for $5 \mathrm{~min}$. Fixation step was repeated. Finally, cells were resuspended in $15 \mu \mathrm{l}$ of fixative solution and dropped onto prewarmed $\left(37^{\circ} \mathrm{C}\right)$ glass slides. Slides were stained with Giemsa (5\% Giemsa in PBS buffer) for 10 min and washed under running tap water for $3 \mathrm{~min}$.

\subsubsection{Transfection of cells}

\subsubsection{Transfection of NIH - 3 T3 cells with the GFP-pelota construct}

Approximately $4 \times 10^{5}$ fibroblast cells $3 \mathrm{~T} 3$ were plated in a cell chamber with slide (Lab-Tek, Flaskett glass slide, Nanc international, Naperville) and cultured overnight in $5 \mathrm{ml} \mathrm{DMEM}$ medium containing $10 \% \mathrm{FCS}$ and pencillin/streptomycin at $37^{\circ} \mathrm{C}$ and $5 \% \mathrm{CO}_{2} .1 \mu \mathrm{g}$ of DNA (GFP-pelota) was deluted with the DNA-condensation buffer (buffer EC of the Effection Transfection kit Qiagen, Hilden) to a total volume of $150 \mu 1$, $8 \mu \mathrm{l}$ of enhancer was added to DNA and mixed by vortexing for $1 \mathrm{sec}$. The mixture was incubated at RT for 5 min. $25 \mu \mathrm{l}$ of Effectin Transfection Reagent was added to the DNA-Enhancer mixture, mixed by pipetting and incubated for $10 \mathrm{~min}$ at RT to allow complex formation. $1 \mathrm{ml}$ of cell medium was added to the reaction tube, mixed and 
immediately added into the cell chamber. Cells were incubated overnight at $37^{\circ} \mathrm{C}$ and $5 \% \mathrm{CO}_{2}$ to allow for gene expression. The glass slide of the culture chamber was rinsed with PBS and then fixed with methanol for $5 \mathrm{~min}$. One drop of mounting medium with DAPI (Vector, Burfingame) was dispensed onto the slide. Fluorescent cells were visualised with a Olympus BX60 microscope using a 60X Neofluor lens, photographed using digital camera and analysed using analysis 3.0 soft imaging system.

\subsubsection{Transfection of ES cell with the GFP-pelota construct}

ES cells were electroporated with the linearized GFP-pelota construct as described in 2.2.16.1.3. Transfected ES cells were cultured for 10 days in ES medium containing $400 \mu \mathrm{g} / \mathrm{ml}$ G418. Resistant ES-clones were picked, trypsinized and each clone was transferred to a well of 24 well plate. The cells were cultured for another two days at $37^{\circ} \mathrm{C}$, $5 \% \mathrm{CO}_{2}$, and frozen as described in section 2.2.16.1.2.

\subsubsection{Immunostaining}

Recombinant GFP-Pelota-ES cells were treated with trypsin for $5 \mathrm{~min}$ at $37^{\circ} \mathrm{C}$ and centrifuged at $250 \mathrm{xg}$ for $5 \mathrm{~min}$. Cells were resuspended in 4\% paraformaldhyde / PBS for 15 min and dropped onto a glass slide. Slides were blocked in PBS with 10\% FCS for 30 min, then incubated with anti- $\gamma$-tubulin monoclonal antibody (Sigma GTU-88) at $1: 200$ dilution in PBS with 4\% FCS for $1 \mathrm{hr}$, washed three times with PBS, incubated with a FITC-conjugated donkey anti-mouse IgG antibody (Sigma, 1 : 200 dilution) in PBS for $1 \mathrm{hr}$, washed three times in PBS and then mounted in vectashield with DAPI. 


\section{RESULTS}

\subsection{Expression of mouse pelota gene}

\subsubsection{Expression of the pelota gene in different tissues of the adult mouse and during prenatal development of the mouse}

To determine the expression of pelota gene in different tissues of the adult mouse, $20 \mu \mathrm{g}$ of total RNA from testis, spleen, liver, lung, heart and brain was size fractionated in $1 \%$ agarose gel containing formaldehyde and transferred to nitrocellulose membranes. Equivalent loading and integrity of the RNA samples were confirmed by staining of the $28 \mathrm{~S}$ and $18 \mathrm{~S}$ rRNA with ethidium bromide in the gel before transferring onto nitrocellulose membranes (Fig. 3.1 B). The Northern blot was hybridised with ${ }^{32} \mathrm{P}$-labeled mouse pelota cDNA. A $1.6 \mathrm{~kb}$ transcript of the pelota gene was detected in the RNA of all studied tissues. An additional $2.1 \mathrm{~kb}$ pelota transcript was observed in RNA of the spleen (Fig. 3.1 A). The results of Northern blot hybridization suggest that the $1.6 \mathrm{~kb}$ transcript is expressed ubiquitously, while the $2.1 \mathrm{~kb}$ transcript is exclusively expressed in the spleen. To investigate the expression of the pelota gene during prenatal development, RNA was extracted from the posterior part of $9.5,10.5,11.5,12.5,13.5,15.5$ and 17.5 dpc embryos and analysed for the presence of pelota transcript by RT-PCR using the primer F7 and R7 (Fig. 3.3). A $500 \mathrm{bp}$ amplified product was observed in all studied stages of embryos (Fig. 3.2).

\subsubsection{Expression of mouse pelota gene during testicular development and in the testis of different mutant mice}

To evaluate the expression of the pelota gene during testicular development, Northern blots with testicular RNAs from 5-, 10-, 15-, 20-, 25- and 60- day old mice were hybridised with ${ }^{32} \mathrm{P}$-labeled mouse pelota cDNA. As shown in Figure 3.4 , a $1.6 \mathrm{~kb}$ pelota transcript was detected throughout testis development.

To examine whether the expression of the pelota gene is restricted to spermatogenic cells of the testis, Northern blot analysis with testicular RNA isolated from $\mathrm{W} / \mathrm{W}^{\mathrm{v}}, \mathrm{Tfm} / \mathrm{Y}$, olt/olt and qk/qk mutant mice was performed. As shown in Figure 3.5, a $1.6 \mathrm{~kb}$ pelota 
transcript is expressed in testes of $\mathrm{W} / \mathrm{W}^{\mathrm{V}}$ mutant mice, which lacks spermatogenic cells, in testes of $\mathrm{Tfm} / \mathrm{Y}$ mice, in which spermatogenesis is arrested at the stage of primary spermatocytes and in testes of olt/olt and $\mathrm{qk} / \mathrm{qk}$ mutant mice, in which spermatogenesis is arrested in spermatid stages. These results indicate that the expression of the pelota gene is not restricted to spermatogenic cells of the testis.

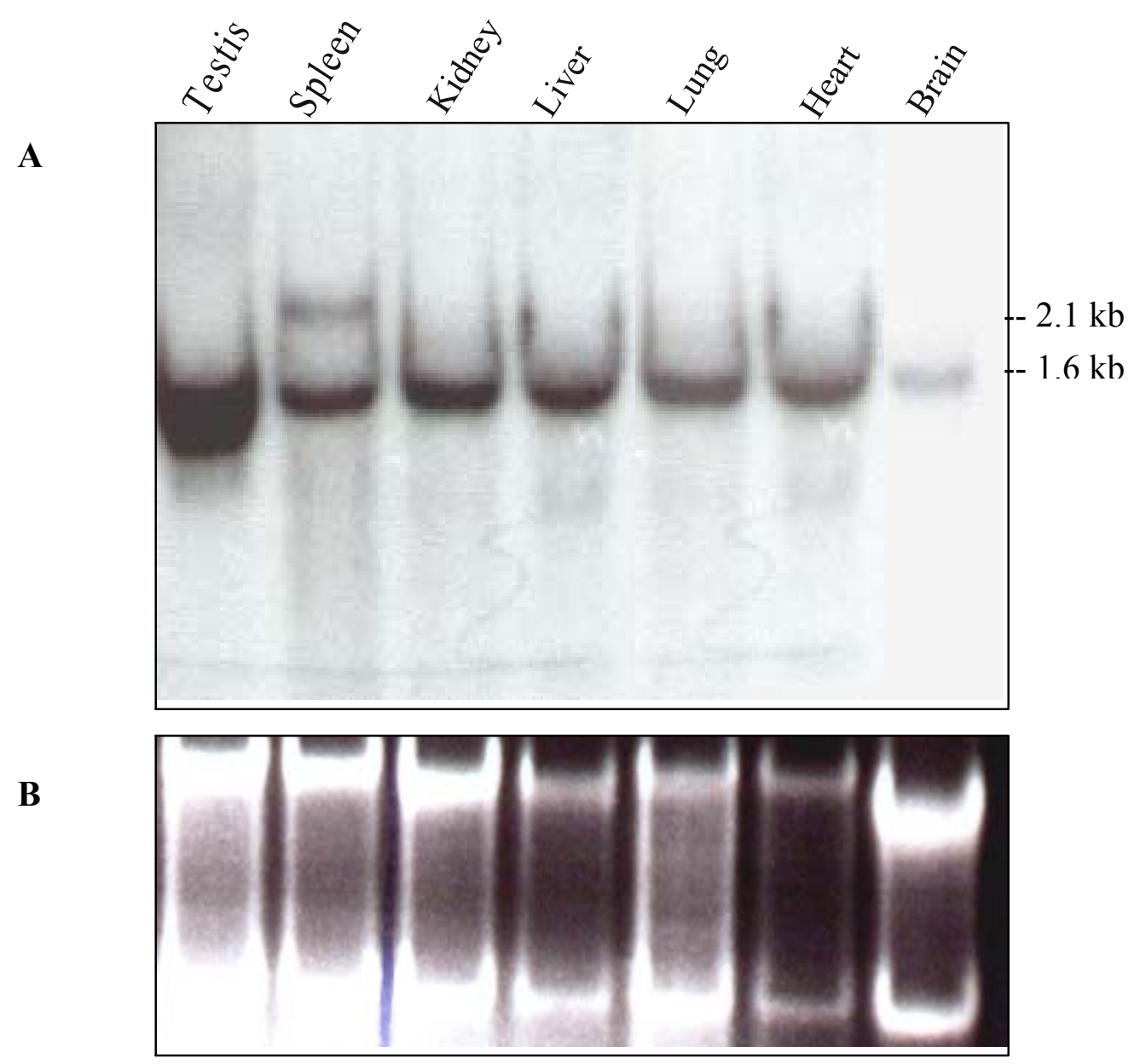

Figure 3.1: Northern blot analysis of pelota gene expression in adult mouse tissues. Total RNA $(20 \mu \mathrm{g})$ was extracted from various tissues (testis, spleen, kidney, liver, lung, heart and brain) of the adult mouse and subjected to Northern blot hybridization using the pelota cDNA as a probe (A). Equivalent loading and integrity of the RNA samples were confirmed by ethidium bromid staining of $28 \mathrm{~S}$ and $18 \mathrm{~S}$ rRNA in the gel before transferring RNA to nitrocellulose membranes (B). 


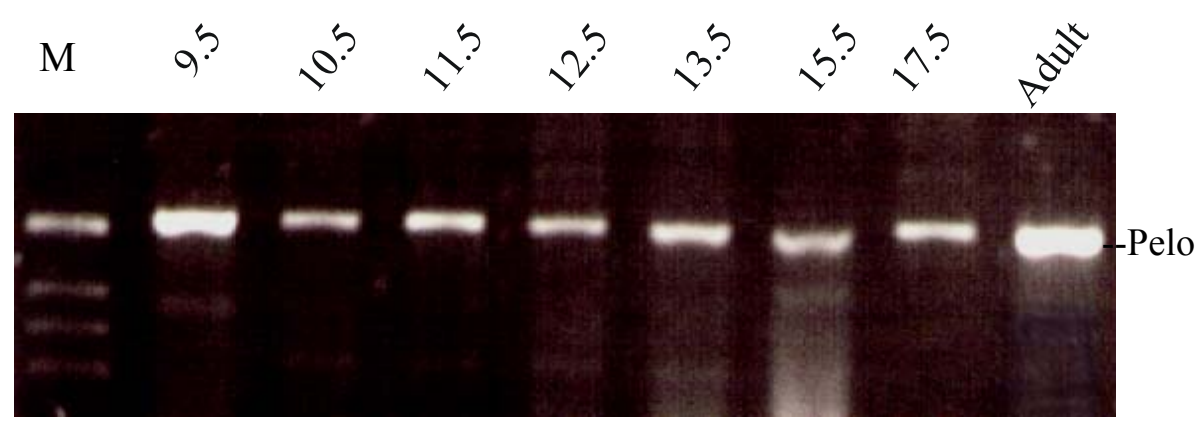

Figure 3.2: RT-PCR analysis of pelota gene expression during fetal development. RNA was isolated from the abdomen of single mouse embryos of different ages and was reverse transcripted using oligo $(\mathrm{dT})_{17}$ primer. Subsequent PCR amplification was performed with oligonucleotide primers $\mathrm{F}_{7}$ and $\mathrm{R}_{7}$ (Fig. 3.3). The RT-PCR products were electrophoresed on a $1.5 \%$ agarose-gel and stained with ethidium bromide; a 500 bp pelota cDNA fragment was amplified. M, corresponds to molecular weight marker. 


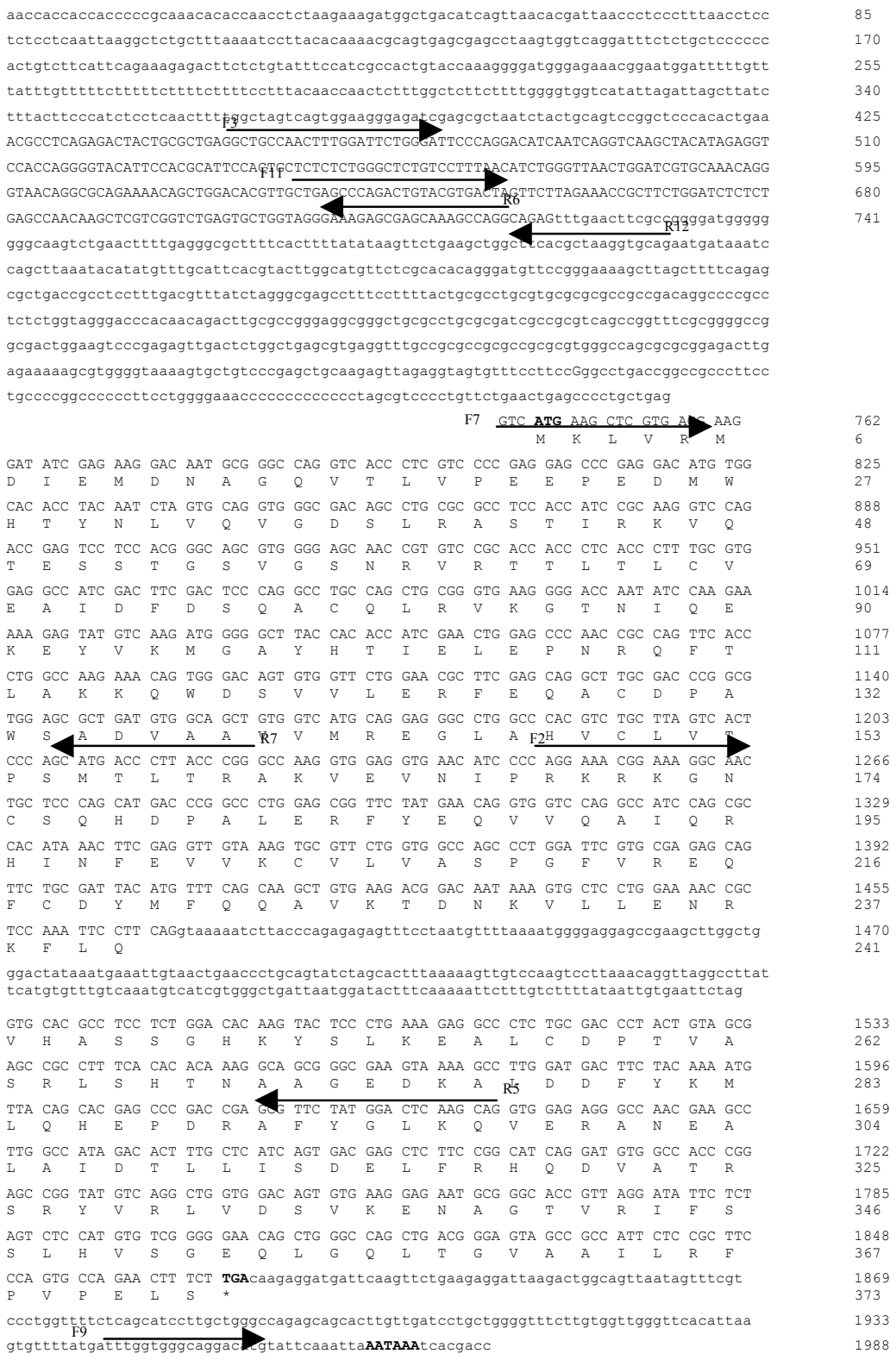

Figure 3.3: Nucleotide sequence of the mouse pelota gene. Nucleotide sequences of exons are shown in uppercase letters; 5' and 3' flanking regions and intronic sequences are in lowercase letters. Numbering of nucleotide and amino acid sequences are given at the right side. Translation intiation codon (ATG), stop codon (TGA) and AATAAA polyadenylation signal are written in bold. The positions of primers used in this studies are marked with arrows. 


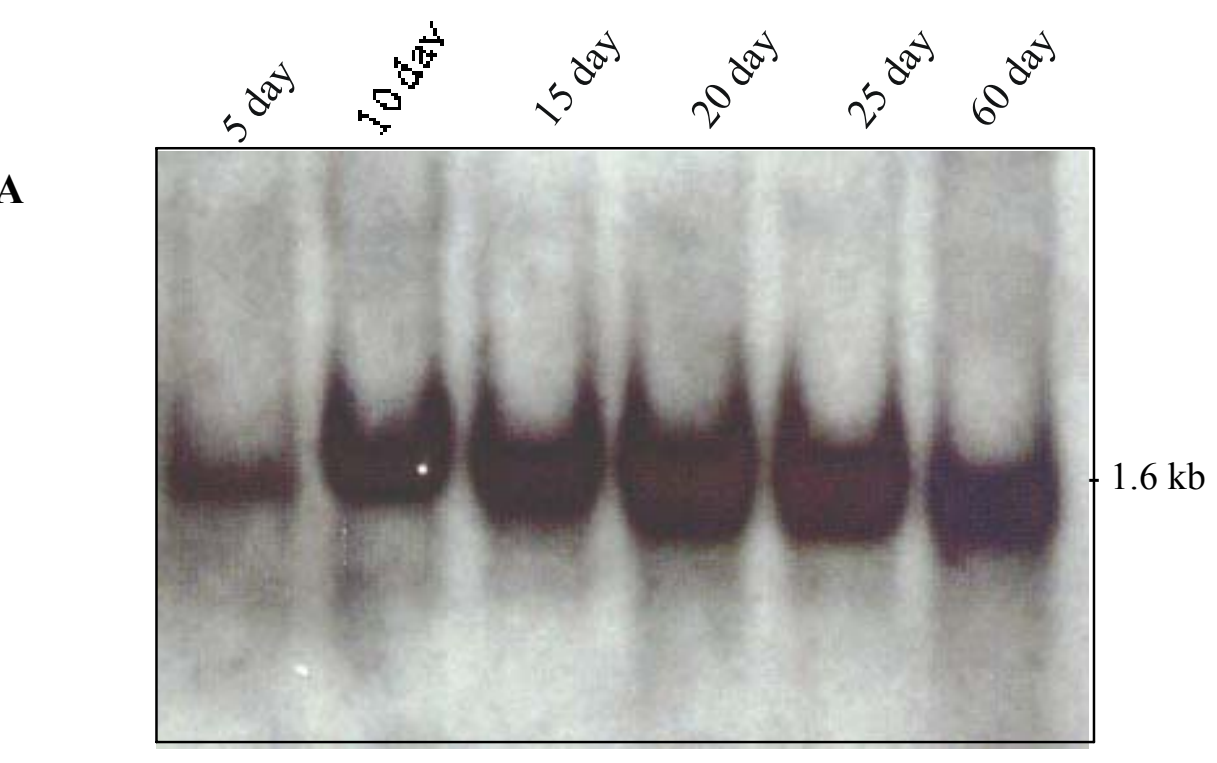

B

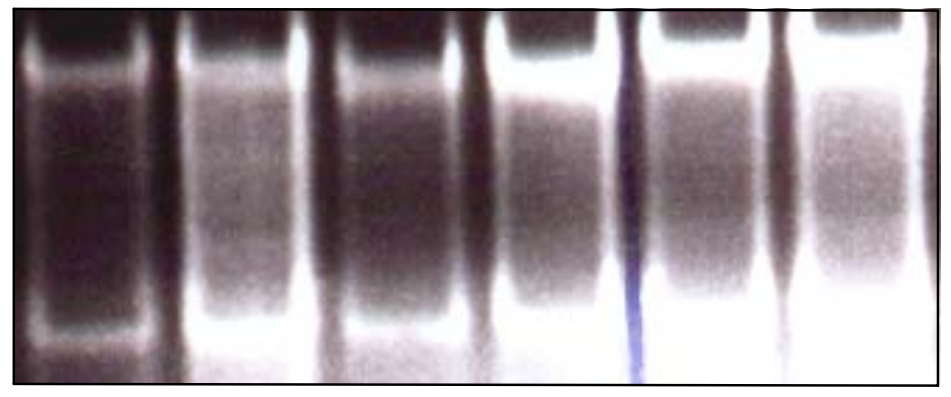

Figure 3.4: Northern blot analysis of mouse pelota gene expression during testicular development. (A) Total testicular RNA isolated from 5-, 10-, 15-, 20-, 25- and 60- day old mice was hybridized with mouse pelota cDNA fragment. (B) Equivalent loading and integrity of the RNA samples were confirmed by ethidium bromide staining of $28 \mathrm{~S}$ and $18 \mathrm{~S}$ rRNA in the gel. 


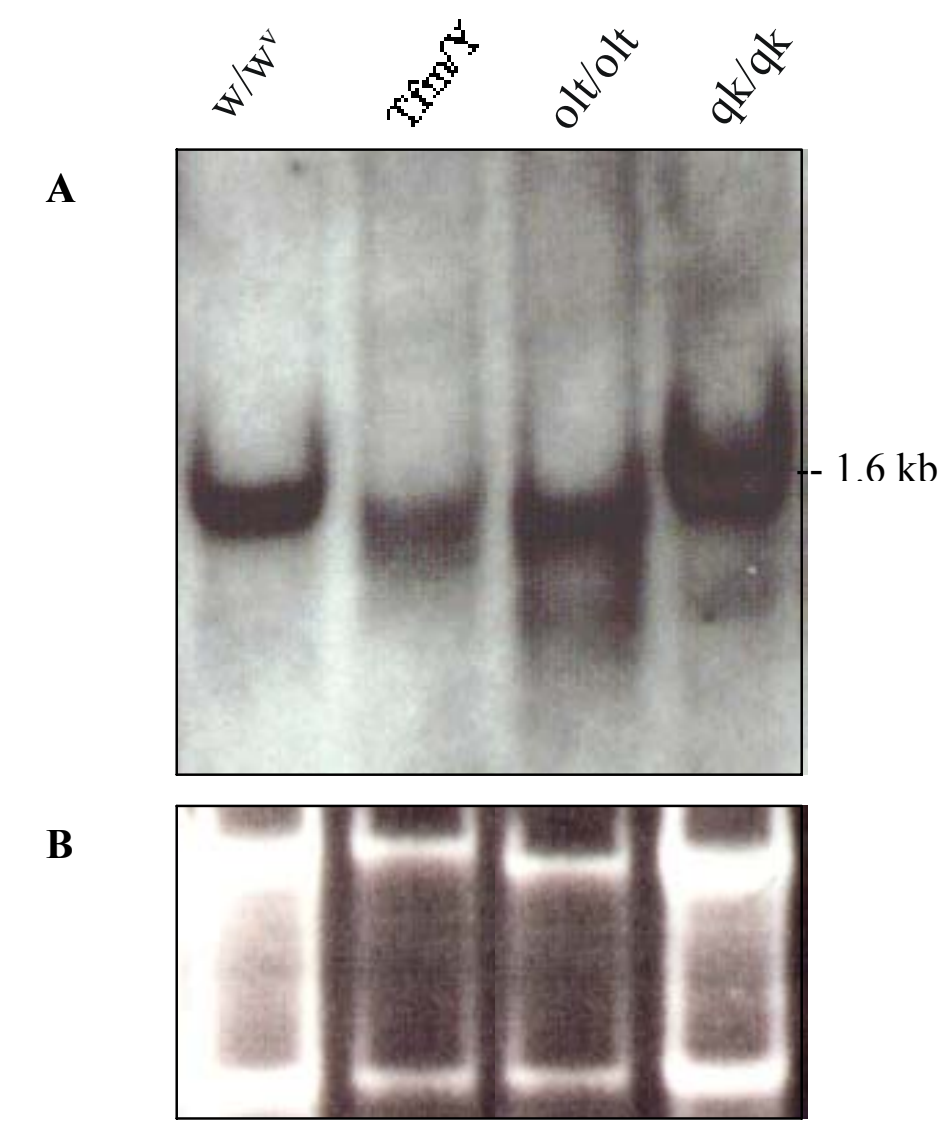

Figure 3.5: Northern blot analysis of pelota gene expression in testes of different mutant mice. (A) Total testicular RNA isolated from $\mathrm{w} / \mathrm{w}^{\mathrm{v}}, \mathrm{Tfm} / \mathrm{Y}$, olt/olt and $\mathrm{qk} / \mathrm{qk}$ mutant mice was hybridized with the mouse pelota cDNA fragment. (B) Integrity of RNA was checked by staining the $28 \mathrm{~S}$ and $18 \mathrm{~S}$ rRNA with ethidium bromide in the gel. 


\subsection{Homologous recombination}

\subsubsection{Isolation and restriction mapping of the pelota gene}

A genomic clone (Melo1) containing the pelota gene was isolated from a genomic mouse phage library (Stratagen, La Jolla, CA) by Dr. R. Shamsadin (Institute of Human Genetics, Göttingen). A $14 \mathrm{~kb}$ BamHI fragment containing the pelota gene was isolated from the phage clone (Melo1) and was subcloned into the Bam HI site of pGEM 32f(t) vector to produce clone $16 \mathrm{~kb}$ (Fig. $3.6 \mathrm{~A}$ ). The restriction map of the $14 \mathrm{~kb}$ BamHI fragment was determined (Fig. 3.6 A) and the mouse pelota gene was sequenced (Fig. 3.3). The mouse pelota gene consists of 3 exons. Exon 1 contains the 5' untranslated sequence, while exons 2 and 3 contain the coding sequence and the 3' untranslated region.

\subsubsection{Construction of the pelota targeting vector}

To disrupt the pelota gene in the mouse, a replacement targeting vector was designed to delete the $3.1 \mathrm{~kb}$ SpeI/EcoRI fragment containing a sequence of exons 2 and 3 and replaced by the neomycin phosphotransferase $(\mathrm{NeO})$ gene under the control of the phosphoglycerate kinase promoter. Introduction of a negative selection marker, the herpes simplex virus thymidine kinase (Tk) gene, at the 3' end of the construct (Fig. 3.9) enabled us to use positive and negative selection (Mansour et al., 1988).

\subsubsection{Subcloning of the $16 \mathrm{~kb}$ pelota genomic fragment}

The DNA of the clone $16 \mathrm{~kb}$ (Fig. $3.6 \mathrm{~A}$ ) was digested with the restriction enzyme SpeI. The $9 \mathrm{~kb}$ and $6 \mathrm{~kb}$ SpeI fragments were purified from the agarose gel. The $9 \mathrm{~kb}$ SpeI fragment includes a $6 \mathrm{~kb}$ genomic fragment and the pGEM $32 \mathrm{f}(\mathrm{t})$ vector. This fragment was self-ligated to give the clone $9 \mathrm{~kb}$ SpeI (Fig. 3.6 C). The 6-kb/SpeI genomic fragment was subcloned into the SpeI digested pBluescript vector to produce the clone $6 \mathrm{~kb}$ SpeI (Fig. 3.6 B). 


\subsubsection{Subcloning of the 3' flanking region of the pelota gene into the pPNT vector}

The $4 \mathrm{~kb}$ HindIII/SpeI fragment located in the 3' flanking region of the pelota gene was isolated from the clone $6 \mathrm{~kb}$ SpeI (Fig. 3.6 B) and was subcloned into the HindIII/SpeI site of pZero vector to create the clone 4H/S (Fig. 3.6 D). The DNA of clone $4 \mathrm{H} / \mathrm{S}$ was digested with EcoRI and the $3 \mathrm{~kb}$ EcoRI fragment was purified from the agarose gel and ligated with the EcoRI digested pPNT vector (Fig. 3.7 A) to produce the clone 1 (Fig. 3.7 B).

\subsubsection{Subcloning of the 5' flanking region in the pPNT vector}

DNA of the clone $9 \mathrm{~kb}$ SpeI (Fig. 3.6 C) was digested with XbaI/SpeI, the resulting $4.8 \mathrm{~kb}$ $\mathrm{XbaI} / \mathrm{SpeI}$ fragment was purified from the agarose gel and subcloned into the $\mathrm{XbaI} / \mathrm{SpeI}$ site of the pBluescript vector to produce the clone $5 \mathrm{X} / \mathrm{Sp}$ (Fig. $3.6 \mathrm{E}$ ). Finally, the $4.8 \mathrm{~kb}$ NotI/XhoI fragment was isolated from the clone $5 \mathrm{X} / \mathrm{Sp}$ and inserted into clone 1 (Fig. 3.7B) to give the final targeted vector pelo-Neo-Tk (Fig. 3.7 C). The DNA of the construct pelo-Neo-Tk was digested with different restriction enzymes to confirm the orientation of the cloned fragments in the pPNT vector (Fig. 3.8). The replacement vector pelo-Neo-Tk was linearized at the unique NotI site present in the polylinker site of the pPNT vector before electroporation.

\subsubsection{Subcloning of the 5' external probe}

The $1.3 \mathrm{~kb}$ EcoRI/XbaI fragment was isolated from the clone $9 \mathrm{~kb}$ SpeI (Fig. $3.6 \mathrm{C}$ ) and inserted into the EcoRI/XbaI site of pBluescript to produce clone 1.3 E/X (Fig. 3.6 F). The DNA of the clone 1.3 E/X was then double digested with EcoRI/XbaI and the $1.3 \mathrm{~kb}$ fragment was extracted from the agarose gel and used as 5' external probe for hybridization in the Southern blot with DNA extracted from the recombinant ES-clones. 
A. Clone $16 \mathrm{~kb}$

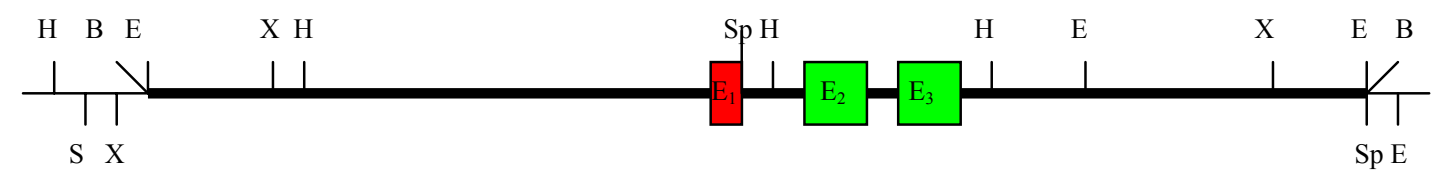

B. Clone $6 \mathrm{~kb}$ SpeI

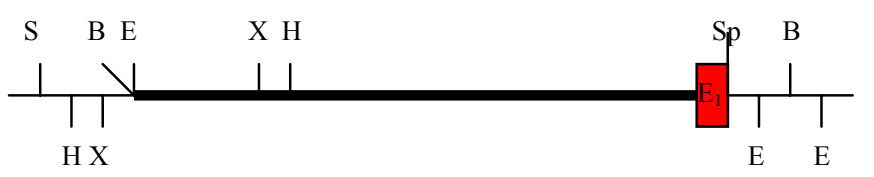

C. Clone $9 \mathrm{~kb}$ SpeI

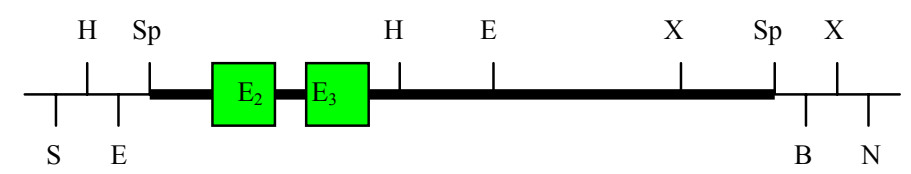

D. Clone $4 \mathrm{H} / \mathrm{S}$

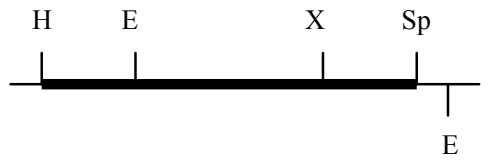

\section{E. Clone $5 \mathrm{X} / \mathrm{Sp}$}

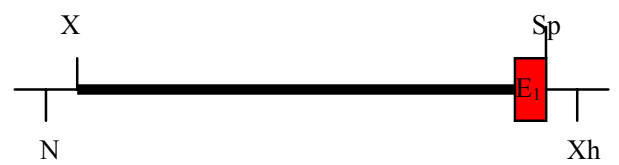

\section{F. Clone 1.3 E/X}

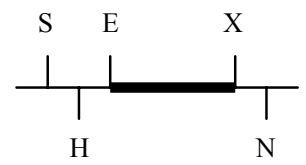

Figure 3.6: Restriction map of the clone $16 \mathrm{~kb}$. The cloning strategy for subcloning the 5 ' and $3^{\prime}$ regions of the pelota gene and subcloning of the 5'external probe. The restriction sites were elaborated for the following enzymes shown: B, Bam HI; E, EcoR I; H, Hind III; S, Sal I; Sp, Spe I; X, Xba I; $\mathrm{Xh}$, Xho I; N, Not I. The exons of pelota are shown as color boxes. The cloned fragments were shown as bold bars. 
A. pPNT

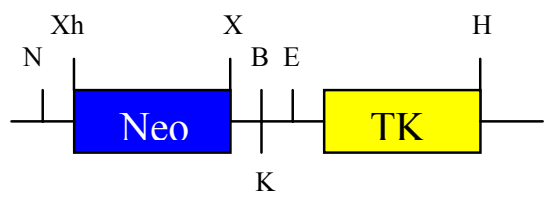

B. Clone 1

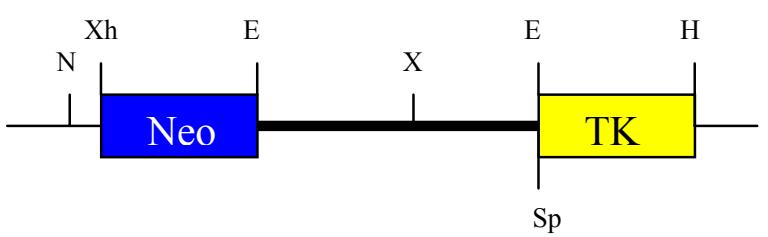

B. targeted vector Pelo-Neo-TK

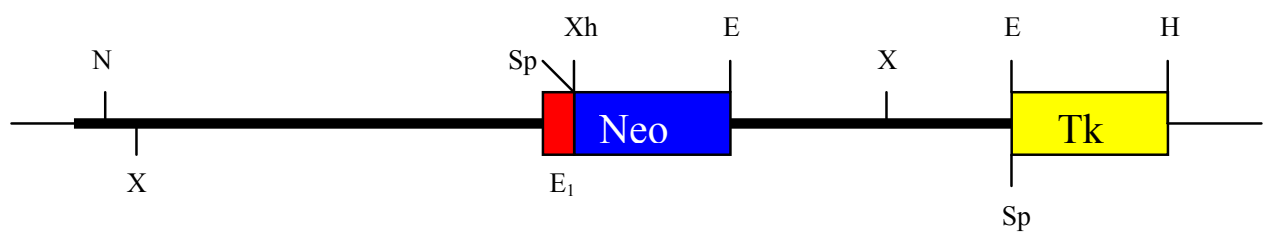

Figure 3.7: Strategy to subclone the 5'and 3' flanking regions of the pelota gene in the pPNT vector. Restriction sites for the following enzymes are shown: B, Bam HI; E, EcoR I; H, Hind III; K, Kpn I; Sp, Spe I; X, Xba I; Xh, Xho I; N, Not I. The cloned fragments are shown as bold bars. 


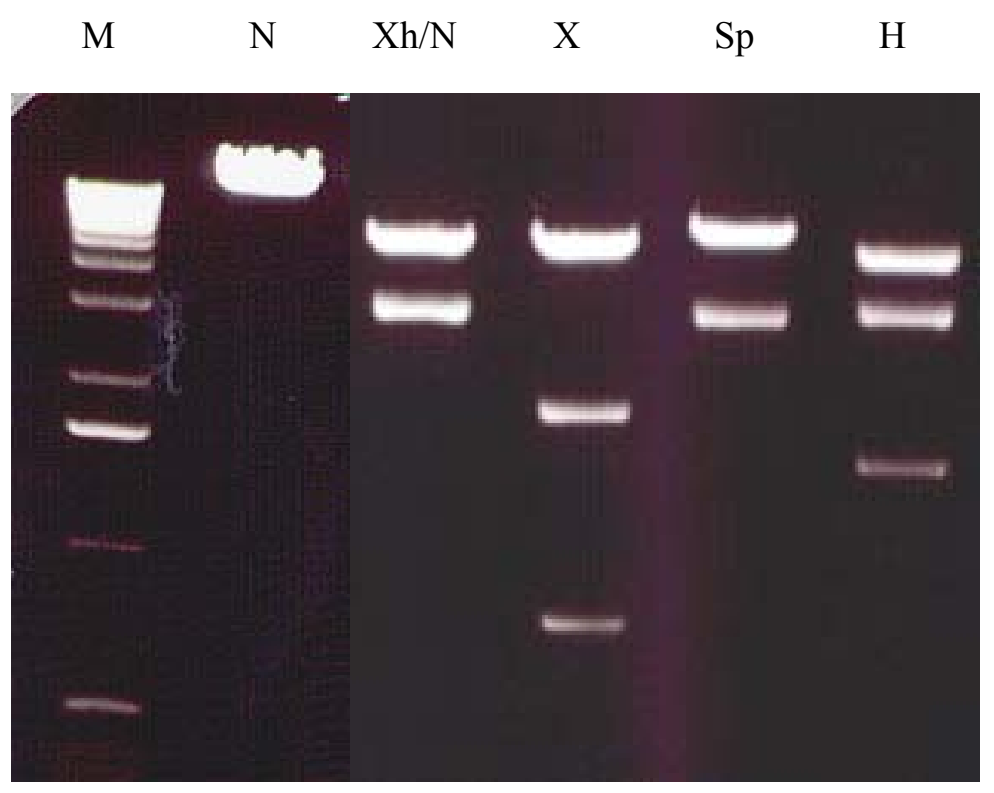

Figure 3.8: The restriction digestion analysis of the targeted vector Pelo-Neo-Tk with different enzymes to confirm the correct orientation of the 5'and 3' fragments of the pelota gene in pPNT vector.N, NotI; Xh, XhoI; X, XbaI, S, SpeI; H, HindIII. M, 1 kb-DNA ladder (Gibco / BRL). 


\subsubsection{Electroporation of the RI ES-cells and screening of ES-clones for homologous recombination events.}

The ES cell line RI was cultured as described (2.2.16.1.2). Confluent plates were washed in PBS buffer, trypsinized and the cells were suspended in the same buffer at $2 \times 10^{7}$ cells $/ \mathrm{ml}$. Aliquots of this cell suspension were mixed with $35 \mu \mathrm{g}$ of linearized targeted vector pelo-Neo-Tk and electroporated at $250 \mathrm{~V}$ and $500 \mu \mathrm{F}$ using a Bio-Rad Gene Pulser apparatus. The cells were plated onto nonselective medium in the presence of G418resistant embryonic mouse fibroblasts. After thirty-six hours, selection was applied using medium containing G418 at $350 \mu \mathrm{g} / \mathrm{ml}$ and gancyclovir at $2 \mu \mathrm{M}$. After 10 days of selection, 96 individual drug-resistant clones were picked into 24-well plates. Three days later, individual recombinant ES-clones were replicated into 24-well trays for freezing and isolation of DNA.

To screen recombinant ES-clones for homologous recombinant events, genomic DNA was extracted from the recombinant ES-clones, digested with EcoRI, electrophoresed and blotted onto nitrocellulose filters. The blots were hybridized with ${ }^{32} \mathrm{P}$-labelled $1.3 \mathrm{~kb}$ EcoRI/XbaI fragment, which is located 5' to the targeted construct (5' probe I in Fig. 3.6 F; 3.9). In case of homologous recombination event, the wild-type locus showed a $15 \mathrm{~kb}$ EcoRI fragment and the targeted locus is $13.5 \mathrm{~kb}$ EcoRI fragment (Fig. 3.9). Of the colonies screened, 4 of 84 clones had undergone correct homologous recombination (Fig. 3.10).

\subsection{Generation of chimeric mice}

Of the 4 homologous recombinant pelota clones (Fig. 3.11), 10-15 cells of 2 homologous recombinant clones were aggregated independently with 2.5-day old embryos of the CD1 mouse strain to generate chimeric mice. Cells from both targeted ES-clones yielded 4 male chimeras. Two chimeric males transmitted the targeted allele through their germ line to produce heterozygous male and female mice. Both germ line transmitting chimeras were bred with $\mathrm{C} 57 \mathrm{Bl} / 6 \mathrm{~J}$ and $129 / \mathrm{Sv}$ females to establish the pelota-disrupted allele on a C57Bl/6J X 129/Sv hybrid and a 129/Sv genetic background. A PCR analysis using primers $F_{10}, R_{12}$ and pgk1 (Fig. 3.3) was performed with isolated DNAs from tail biopsies to determine the genotypes of the $F_{1}$ offspring. A total of 118 animals in $F_{1}$ generation were 
genotyped and 53 mice were defined to be pelota ${ }^{+/}$. Both male and female mice heterozygous for the pelota deletion were phenotypically normal and fertile.
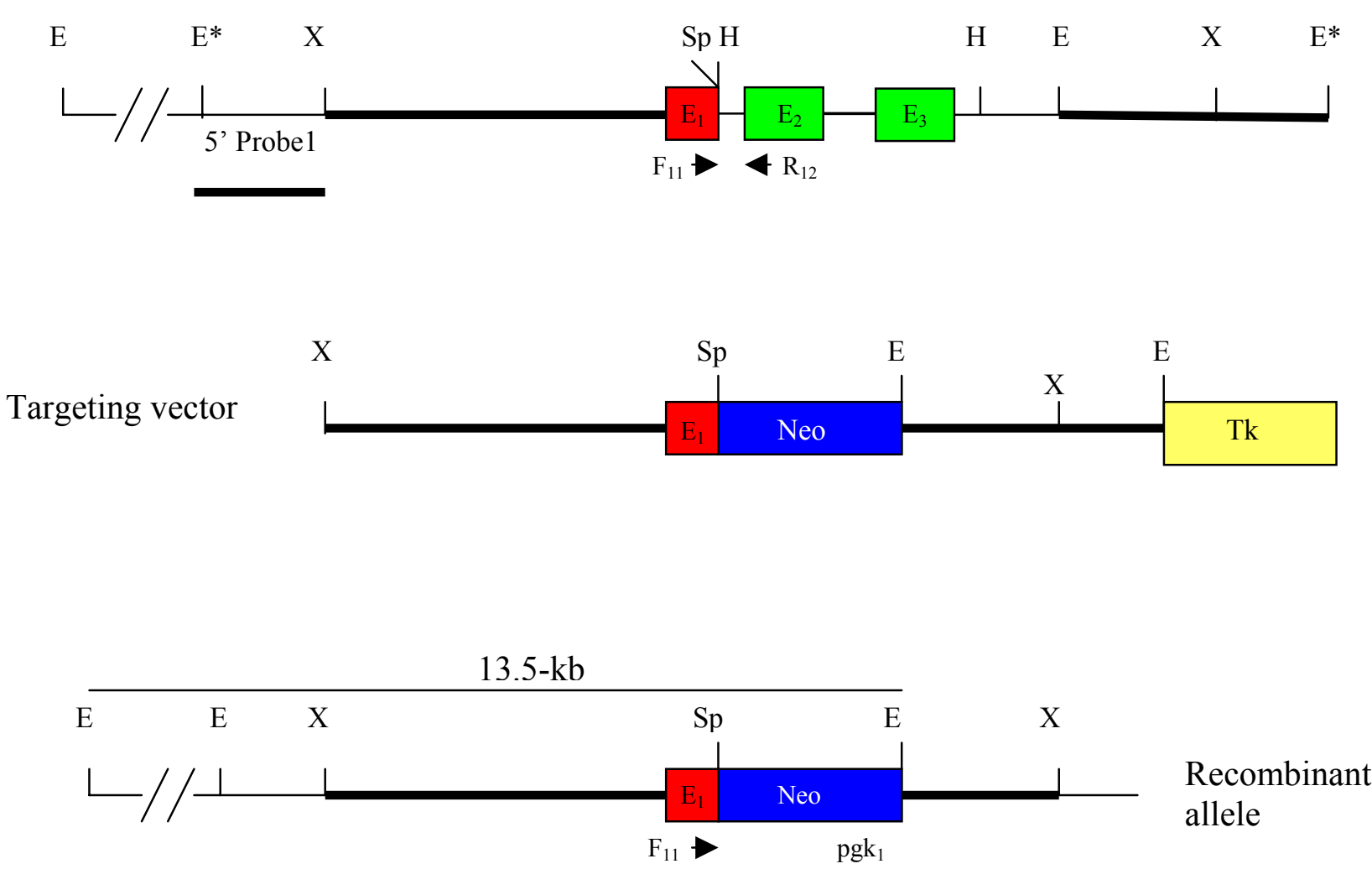

Figure 3.9: Targeted disruption of the pelota gene. Structure of the wild-type, targeting vector and targeted allele are shown together with the relevant restriction sites. A $2 \mathrm{~kb}$ HindIII fragment containing exons 2 and 3 of the gene was replaced by a Pgk-neo selection cassette (Neo). Tk, Thymidine kinase cassette; E, EcoRI; X, XbaI; Sp, SpeI; H, HindIII; E*, EcoRI site from polylinker of phage clone. The primers $\mathrm{F}_{11}, \mathrm{R}_{12}$ and pgk $_{1}$ used to amplify wild-type and targeted allele in PCR assay are shown. 


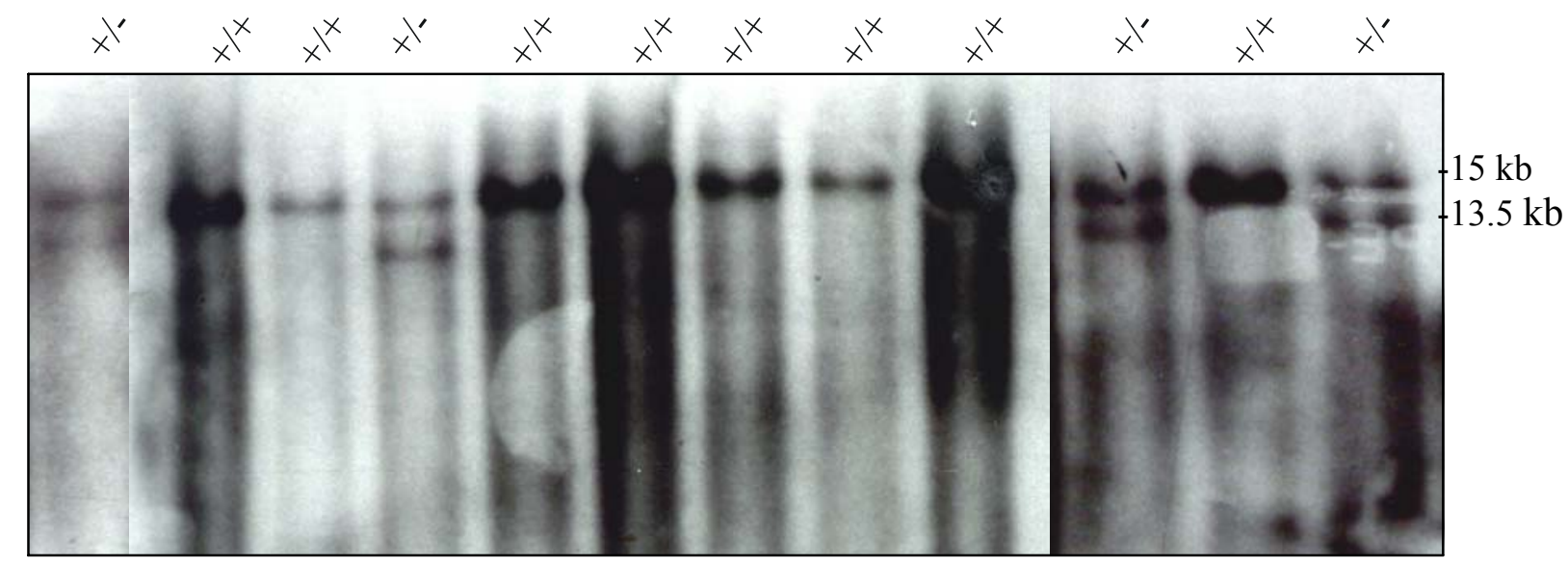

Figure 3.10: Analysis of 12 transfected ES cells clones by Southern blotting. The ES cells DNAs were digested with EcoRI and hybridized with the 5' probe I of the pelota gene (Fig. 3.6; 3.9). Homologous recombination events resulted in a 13.5 kb-hybridizing fragment detected in heterozygote lines (+/-). Homozygote wild-type lines (+/+) showed a $15 \mathrm{~kb}$ fragment. 


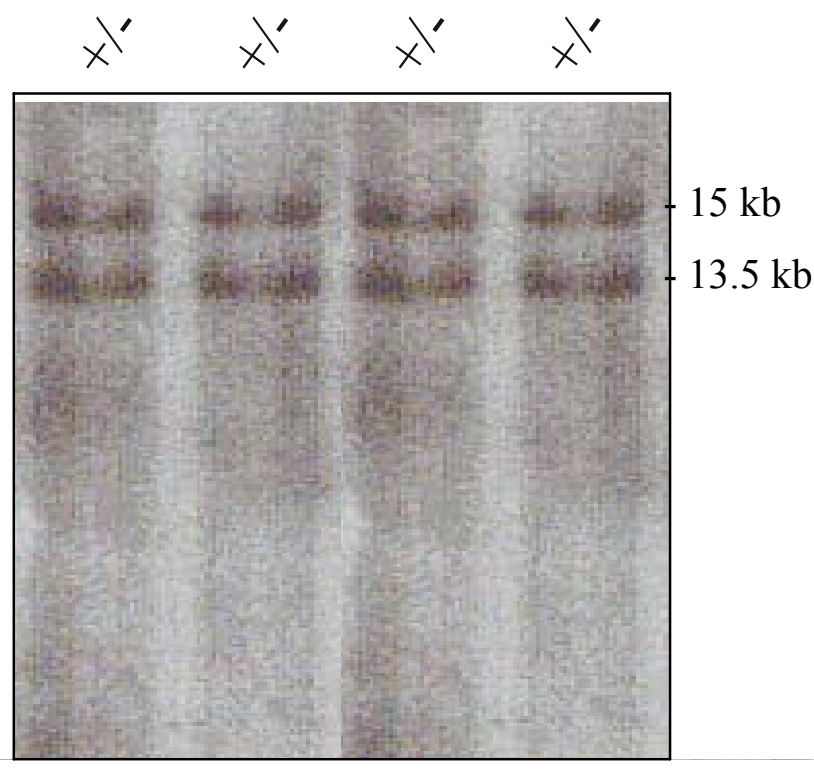

Figure 3.11: Analysis of transfected ES cells lines by Southern blotting. The 4 homologous recombination events yielded a $13.5 \mathrm{~kb}$ hybridizing fragment from the mutant allele and a $15 \mathrm{~kb}$ fragment from wild-type allele. 


\subsection{Pelota mutation results in early embryonic lethality}

Heterozygous animals were intercrossed and the offspring ( 240 mice) were genotyped by PCR analysis at age of 3 weeks (Fig. 3.12). No pelota ${ }^{-/-}$animals were detected among these offspring (Table 3.1). Given that mortality of neonates was not noticed during the first 3 week after birth, this lack of pelota ${ }^{-/-}$mice indicated that pelota deficiency results in embryonic death.

Northern blot with total RNA prepared from testis of pelota $^{+/+}$and pelota $^{+/-}$demonstrated that the level of the $1.6 \mathrm{~kb}$ transcript in testis of pelota $^{+/-}$is lower than that in testis of pelota $^{+/+}$(Fig. 3.13). This result suggests that the deletion of exons 1 and 2 lead to inactivation of the pelota gene.

To assess the consequences of the pelota mutation for embryonic development, embryos were collected from heterozygous intercrosses at different days of gestation. Genomic DNA was isolated from whole embryos, and genotyping was performed by PCR assay using primers $\mathrm{F}_{10}, \mathrm{R}_{12}$ and $\mathrm{pgk}_{1}$ (Fig. 3.9). The PCR analysis of post-implantation embryos dissected from the decidua at embryonic day (E) 8.5, 9.5 and 10.5 showed that none of 31 studied embryos was pelota ${ }^{-/-}$(Table. 3.1). However, empty deciduas, which could account for the resorbtion of pelota ${ }^{-/-}$embryos were detected at E8.5. Resorbed embryos were also noticed at E9.5 and E10.5.

To investigate whether the pelota deficient embryos die during preimplantation stages, morulae (E2.5) and blastocysts (E3.5) were isolated, and their genotypes were determined by PCR (Fig. 3.14 A, B). At E2.5 and 3.5, pelota ${ }^{-/-}$embryos were detected in the expected ratio as defined by Mendelian distribution (Table 3.1). These results suggest that pelota ${ }^{-/-}$ embryos die between E3.5 and E8.5.

To determine the cause and time of embryonic lethality, deciduae at embryonic day 6.5 , $7.5,8.5$ and 9.5 were dissected from uteri of heterozygous females mated to heterozygous males and characterised by light microscopy. The mean number of dissected 6.5-, 7.5-, 8.5and 9.5-day old deciduae was not significantly different from that of the wild-type female mated to wild-type males (Table $3.2 ; 3.3$ ). These results indicate that the implantation of pelota-deficient embryos is not affected. Furthermore, the dissected 6.5-, 7.5-, 8.5- and 9.5-day old deciduas from heterozygous intercrosses showed no obvious morphological differences (Fig. 3.15 A, C, E). The embryos at E7.5, 8.5 and 9.5 were isolated from deciduas, microscopically examined by light microscopy and then genotyped by PCR assay. The wild-type embryos of stage E7.5, E8.5 and E9.5 were much larger than mutant 
embryos (Fig. 3.16 B, D, F). However, we could not isolate embryos of stage E6.5 from the decidua. These embryos were too small. The 6.5-, 7.5- and 8.5-day old deciduas were fixed overnight in $4 \%$ paraformaldhyde, dehydrated and embedded in paraffin. Serial sections of $7 \mu \mathrm{m}$ thick were cut, stained with Giemsa and analysed. At developmental stage E6.5, 41 embryos were histologically examined. All embryos at E6.5 were found to be developed normally at this stage (Table 1 and Fig. 3.16 A, B). However, 16 of 57 histologically examined E7.5 (Table 3.1) showed profound developmental abnormalities and strikingly reduced size (Fig. 3.16 C, D). Histological analysis of 34 embryos at E8.5 revealed that developmental delay was clearly evident by 3 embryos and 4 deciduas were found to lack embryos (Table 3.1 and Fig. 3.16 E, F). All three germ layers namely mesoderm, endoderm and ectoderm seem to be differentiated in the pelota deficient embryos (Fig. 3.17 A, B; 3.18 A, B). The mutant embryos have a well developed layer of extraembryonic ectoderm. The amniotic cavity is developed and amniotic fold consists of amniotic mesoderm and ectoderm. The embryonic mesoderm seems to be formed in the mutant embryos. However, the mutant embryos at E7.5 and E8.5 were completely lacking allantois and chorion (Fig. 3.17 B and 3.18 B).

These results revealed that the development of the pelota deficient embryos up to E6.5 appears be normal but slows down at the E 7.5. After E9.5, no viable pelota ${ }^{-/-}$embryos were observed.

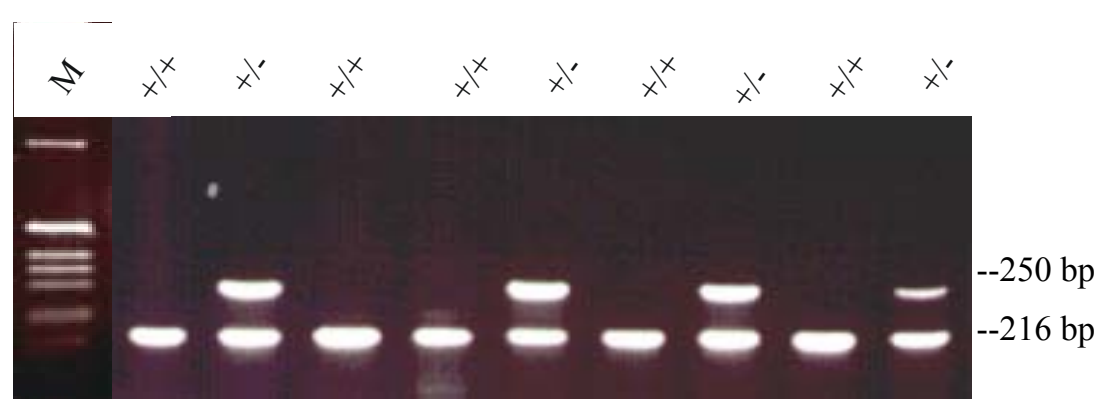

Figure 3.12: Identification of the wild-type and targeted pelota alleles in the genome of 10 offspring from heterozygous intercrosses using a PCR analysis. The PCR products obtained using primers $F_{11}, R_{12}$ and $\mathrm{pgk}_{1}$ (Fig. 3.3) were electrophoresed on 1.5\% agarose gel and stained with ethidium bromide. 
Table 3.1: Viability analysis of pelota ${ }^{-/}$mice and embryos.

A. Genotype of offspring and embryos from pelota $^{+/}$intercrosses.

\begin{tabular}{lllll}
\hline & \multicolumn{3}{c}{ Genotype } \\
\cline { 2 - 4 } & pelota $^{+/+}$ & pelota $^{+/-}$ & pelota $^{-/-}$ & Total \\
\hline Offspring & 83 & 157 & 0 & 240 \\
Embryos,E8.5- E 10.5 & 12 & 19 & 0 & 31 \\
Blastocysts, E 3.5 & 10 & 27 & 11 & 48 \\
Morulae, E2.5 & 8 & 13 & 6 & 27 \\
Blastocysts grown in culture & & & & \\
$\quad$ Normal at E8.5 & 9 & 20 & 0 & 29 \\
$\quad$ ICM atrophied by E8.5 & 0 & 0 & 5 & 5 \\
& & & & \\
\hline
\end{tabular}

B. Histological analysis of embryos in uteri.

\begin{tabular}{lcccc}
\hline & \multicolumn{3}{c}{ Number of embryos from pelota $^{+/}$intercrosses } & \\
\cline { 2 - 4 } Age & Total & Abnormal (A) & Resorbed (R) & Total (A+R) \\
\hline E 6.5 & 41 & 0 & 0 & 0 \\
E 7.5 & 57 & 16 & 0 & 16 \\
E8.5 & 34 & 3 & 4 & 7 \\
\hline
\end{tabular}

Mice, E8.5 - E10.5, and blastocysts were genotyped by PCR assay. All embryos harvested at E3.5 were grown in culture to at least E 8.5 before recovering DNA for genotyping. For histological analysis embryos were fixed, sectioned, stained, and scored as normal or abnormal based on size and general morphology (Example shown in Fig 3.16). Empty deciduas were scored as "Resorbed". 


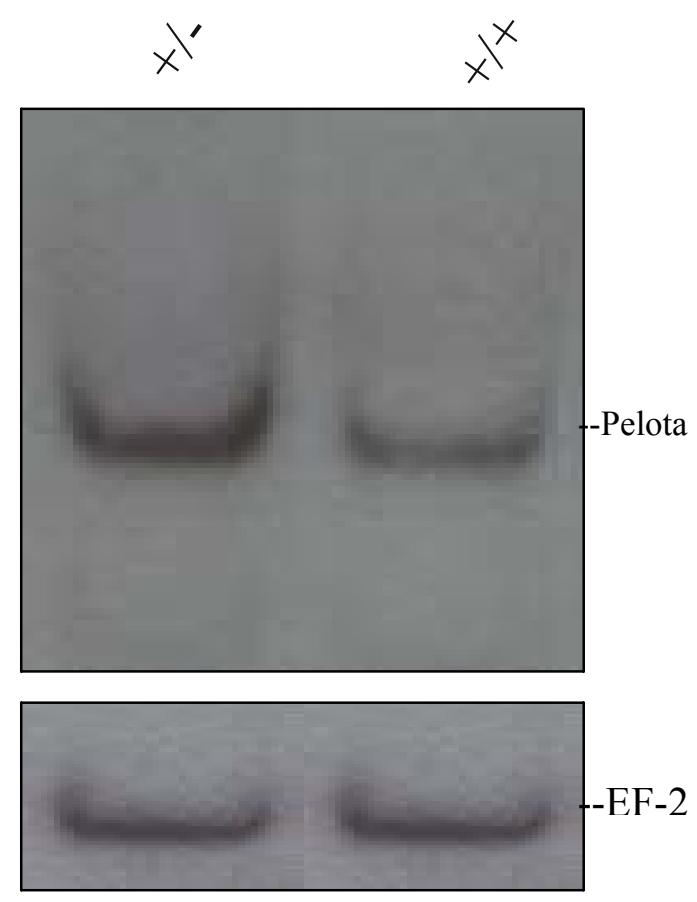

Figure 3.13: Northern blot analysis of testicular RNA. Ten $\mu \mathrm{g}$ of total RNA extracted from wild-type testis and heterozygous pelota testis were analysed by Northern blot hybridization using the pelota cDNA. The blot was rehybridized with the $E F-2$ cDNA. 
A

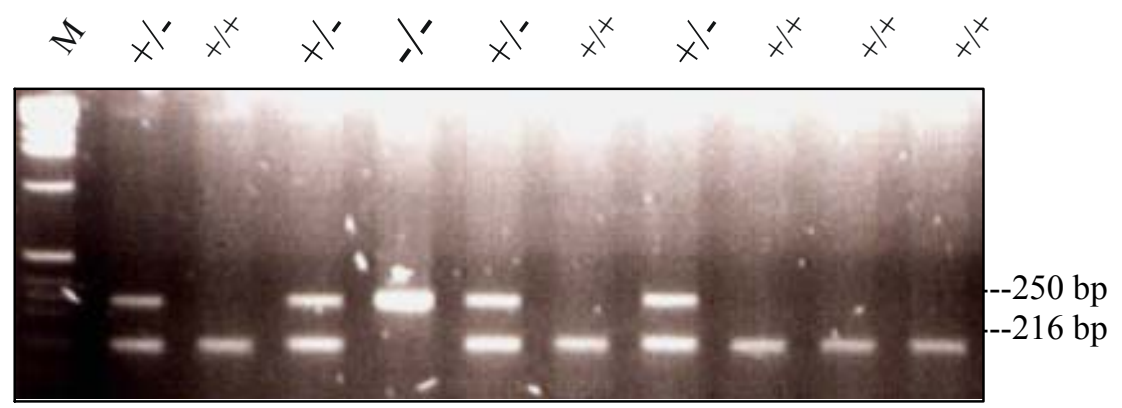

B

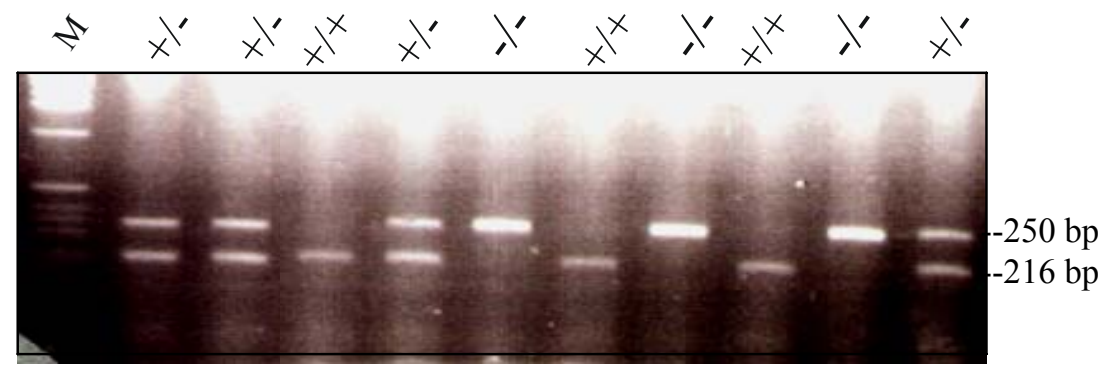

Figure 3.14: PCR genotyping of embryos. E2.5 (A); E3.5 (B). Separate PCR reactions were performed to amplify the wild-type allele (250 bp) and the disrupted allele (216 bp) and the samples were then analyzed on ethidium bromide stained agarose gel. " $\mathrm{M}$ " indicates molecular weight markers. 
Table 3.2 : Mean number of 6.5-, 7.5-, 8.5- and 9.5-day old deciduas from heterozygous and wild-type intercrosses.

\begin{tabular}{lcc}
\hline & \multicolumn{2}{c}{ Mean number } \\
\cline { 2 - 3 } $\begin{array}{l}\text { Developmental } \\
\text { stage of decidua }\end{array}$ & Heterozygous intercrosses & Wild-type intercrosses \\
\hline 6.5-day old & $8.8(4)$ & $10.6(2)$ \\
7.5 -day old & $10(6)$ & $9.8(2)$ \\
8.5-day old & $9.4(9)$ & $10.5(2)$ \\
9.5 -day old & $9.3(3)$ & $11.4(2)$ \\
\hline
\end{tabular}

Number of intercrosses are indicated in parentheses.

Table 3.3 : Number of analysed deciduas of 6.5-, 7.5-, 8.5- and 9.5-day old pregnancies and results of histological analyses from heterozygous pelota intercrosses.

\begin{tabular}{lcccc}
\hline \multirow{2}{*}{$\begin{array}{l}\text { Developmental } \\
\text { stage of decidua }\end{array}$} & Deciduas & Normal & Abnormal & \multirow{2}{c}{$\begin{array}{l}\text { \% of abnormal } \\
\text { embryos }\end{array}$} \\
\cline { 3 - 4 } 6.5-day old & 39 & 39 & 0 & 0 \\
7.5-day old & 59 & 46 & 13 & 22.03 \\
8.5-day old & 86 & 68 & 18 & 20.9 \\
9.5-day old & 28 & 22 & 6 & 21.5 \\
\hline
\end{tabular}


Deciduas
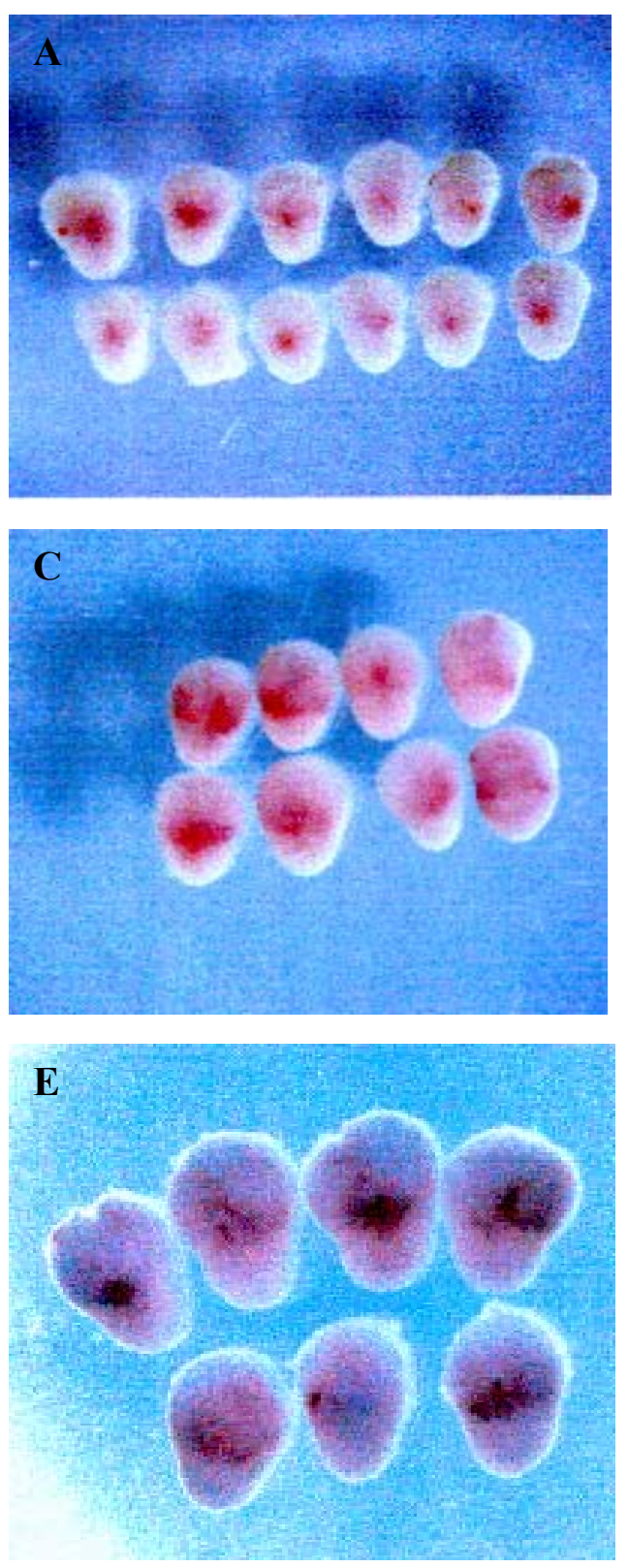

Embryos

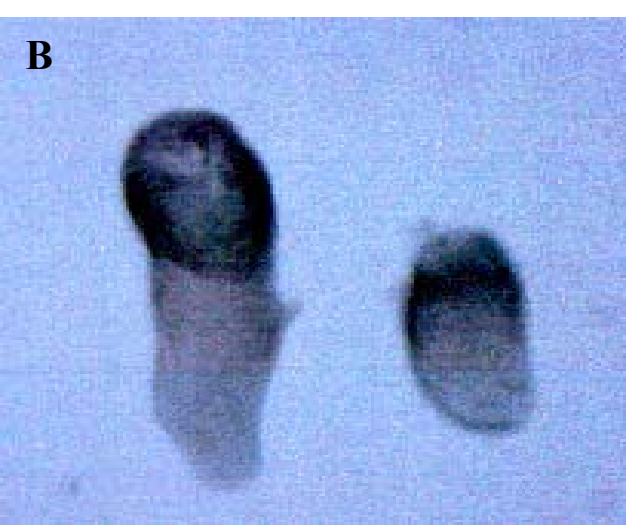

7.6-day old

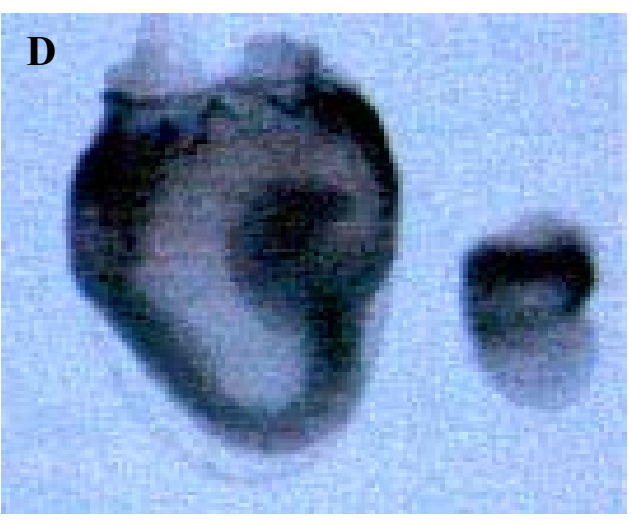

8.5-day old

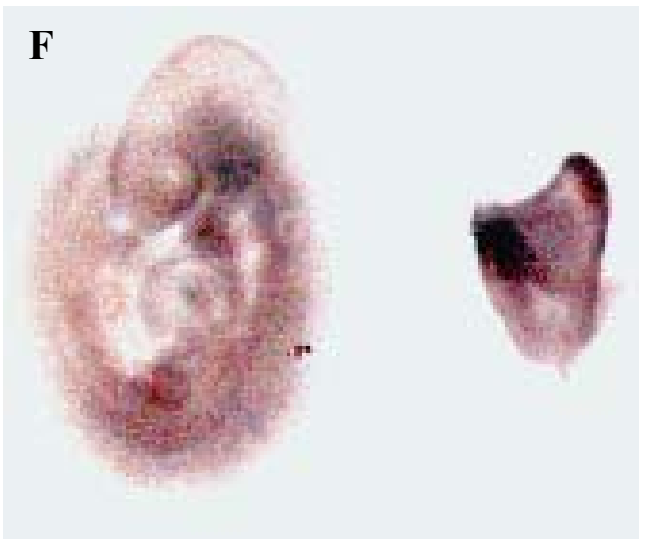

9.5-day old

Figure 3.15: Morphology of deciduas and embryos isolated from heterozygous pelota intercrosses. All deciduas dissected from uteri of pelota ${ }^{+/-}$females mated with pelota $^{+/-}$males at dpc 7.5 (A), 8.5 (C) and 9.5 (E) showed normal development. In contrast two classes of embryos can be distinguished at E7.5, E8.5 and E9.5. The mutant embryos are shown in the right sites of B, D and F. This embryo E7.5 is smaller than its wild-type littermate. The right part of D and F shows a severely affected mutant embryo at E8.5 and E9.5, respectively. They are much smaller than the wild-type embryos, with no sign of organization. 
Control
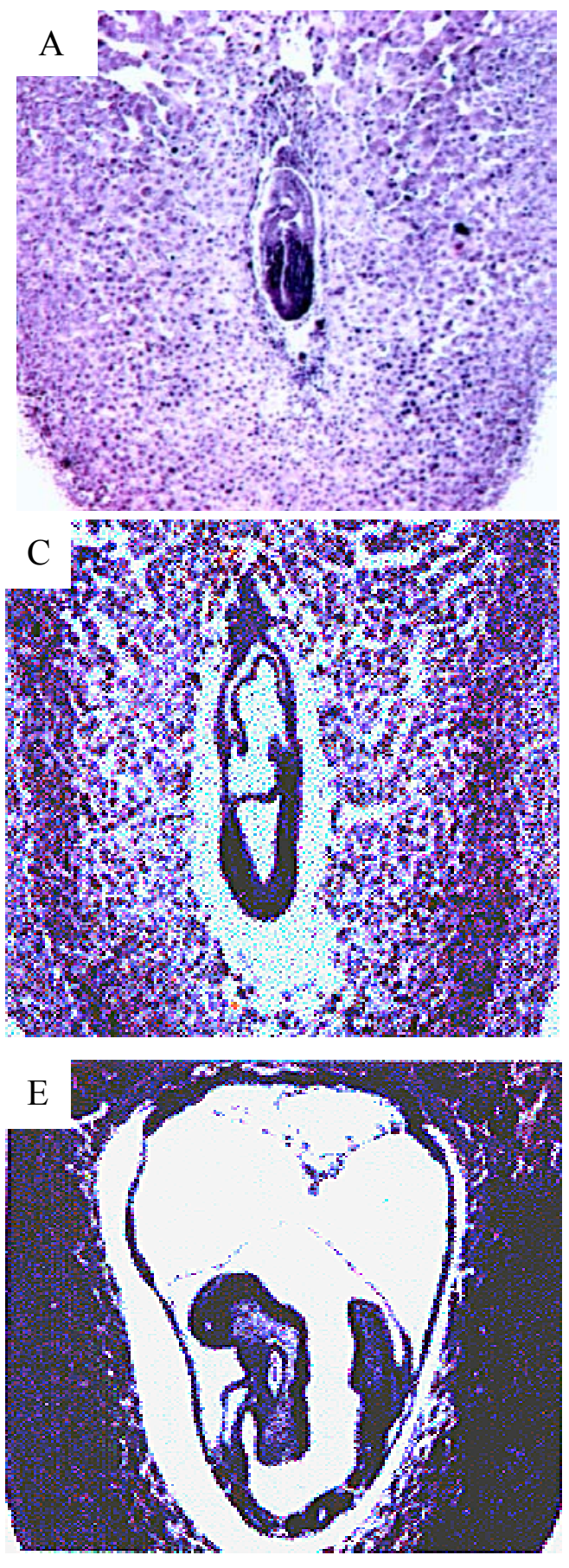

Pelo $^{-/-}$
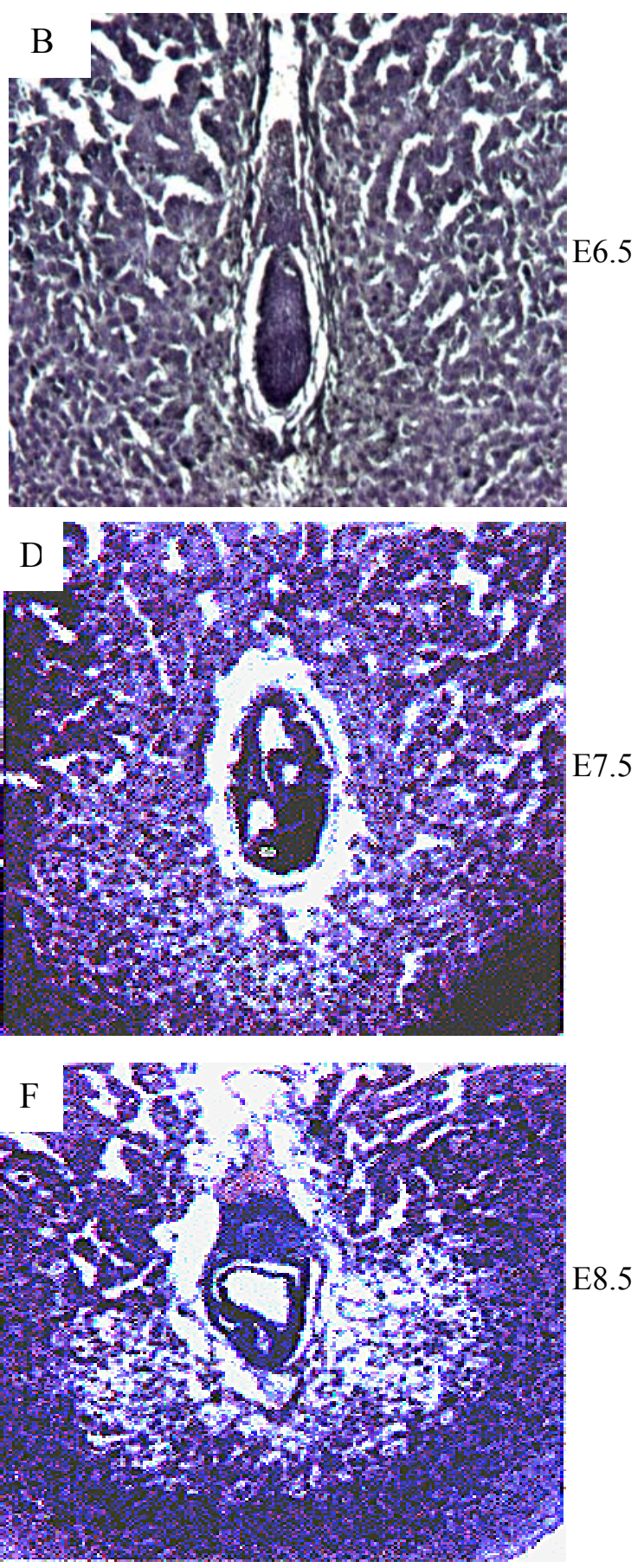

Figure 3.16: Histological analysis of pelota mutant embryos and their wild-type or heterozygous littermates at E6.5, E7.5 and E8.5. At E6.5, all isolated embryos from heterozygous intercrosses exhibited normal development (A, B). At E7.5, 16 of 70 embryos were small and disorganised (D). At E8.5, 8 of 37 embryos were disorganised or resorbed $(\mathrm{F})$. 
A

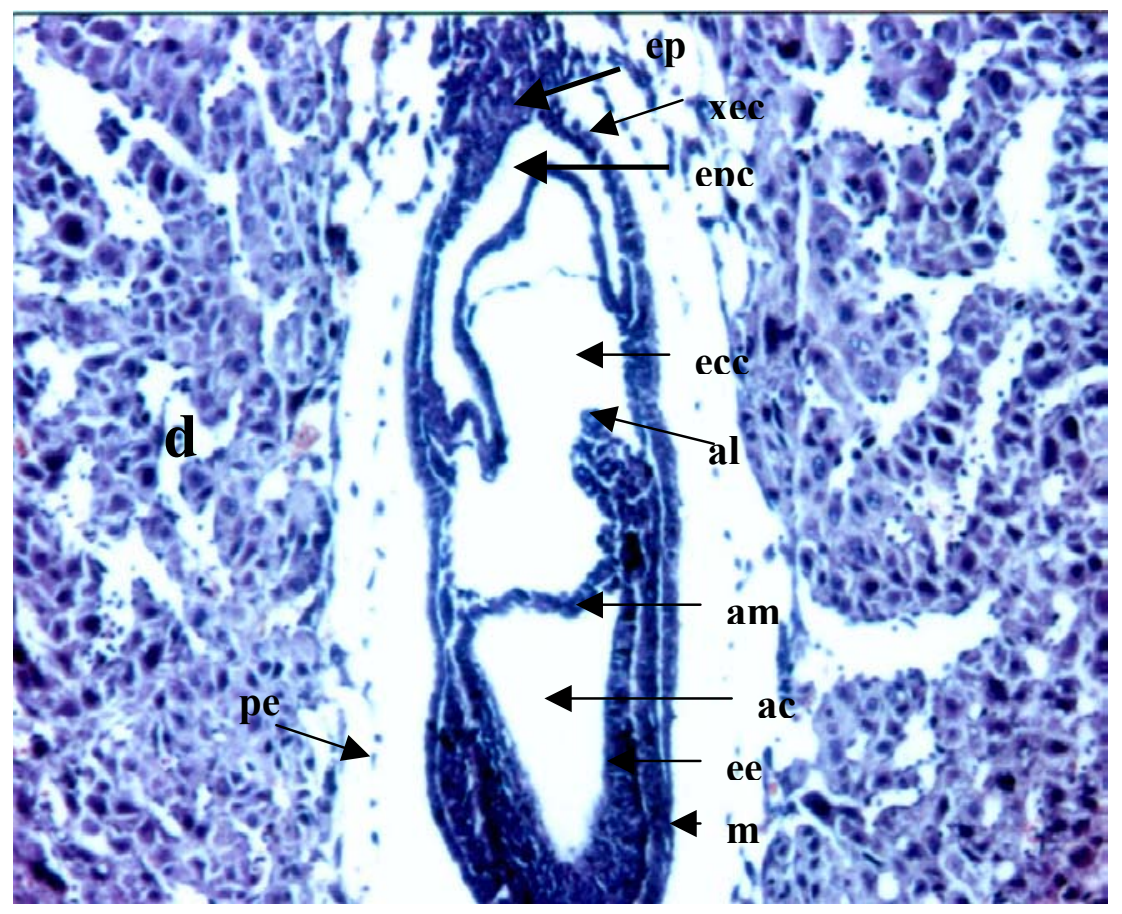

B

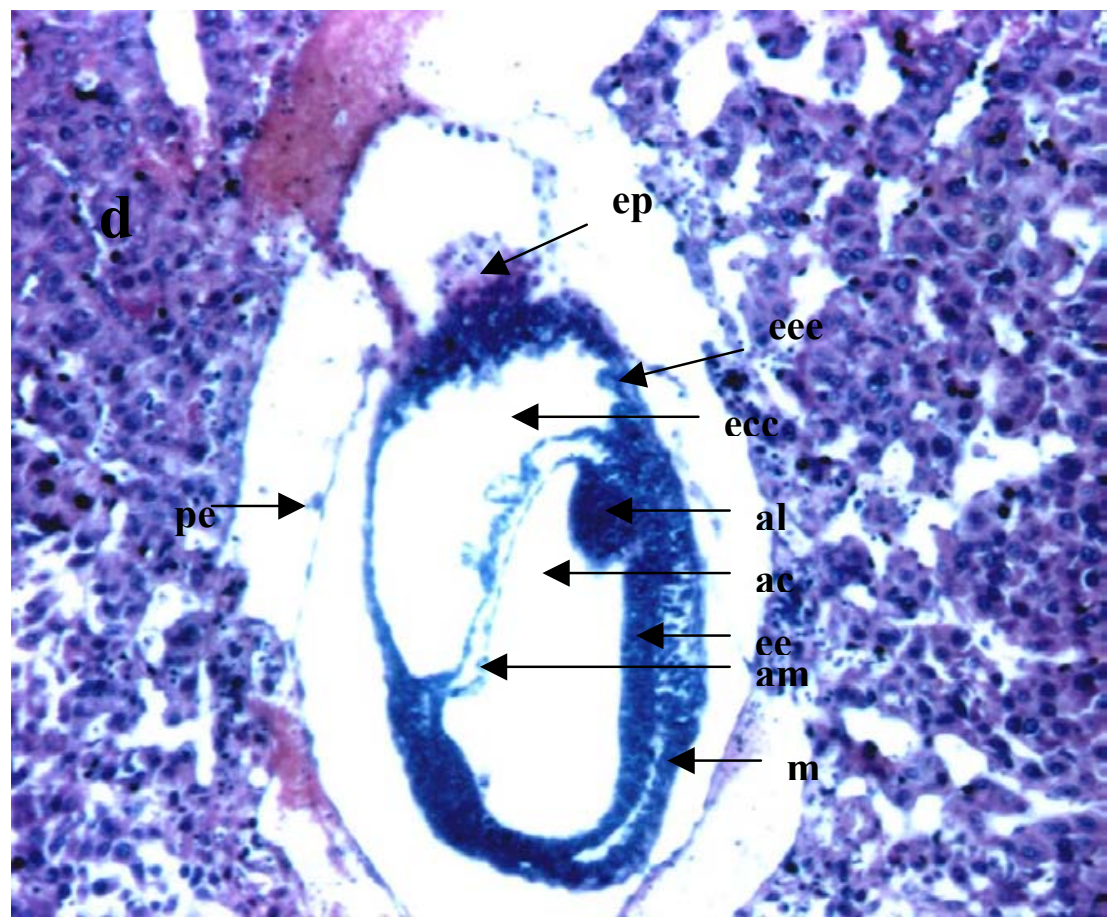

Figure 3.17: Histological analysis of a pelota mutant embryo and its wild-type or heterozygous littermate at E8.5. (A) Wild-type embryo. (B) Mutant embryo is small and disorganised, with a thick mesoderm and thin ectoderm. ep, ectoplacenta; eee, extraembryonic ectoderm; epc, ectoplacental cavity; ecc, exocoelomic cavity; a, allantois; am, amnion; pe, parietal endoderm; ac, amniotic cavity; ee, embryonic ectoderm; m, mesoderm. (d) deciduas. 
A

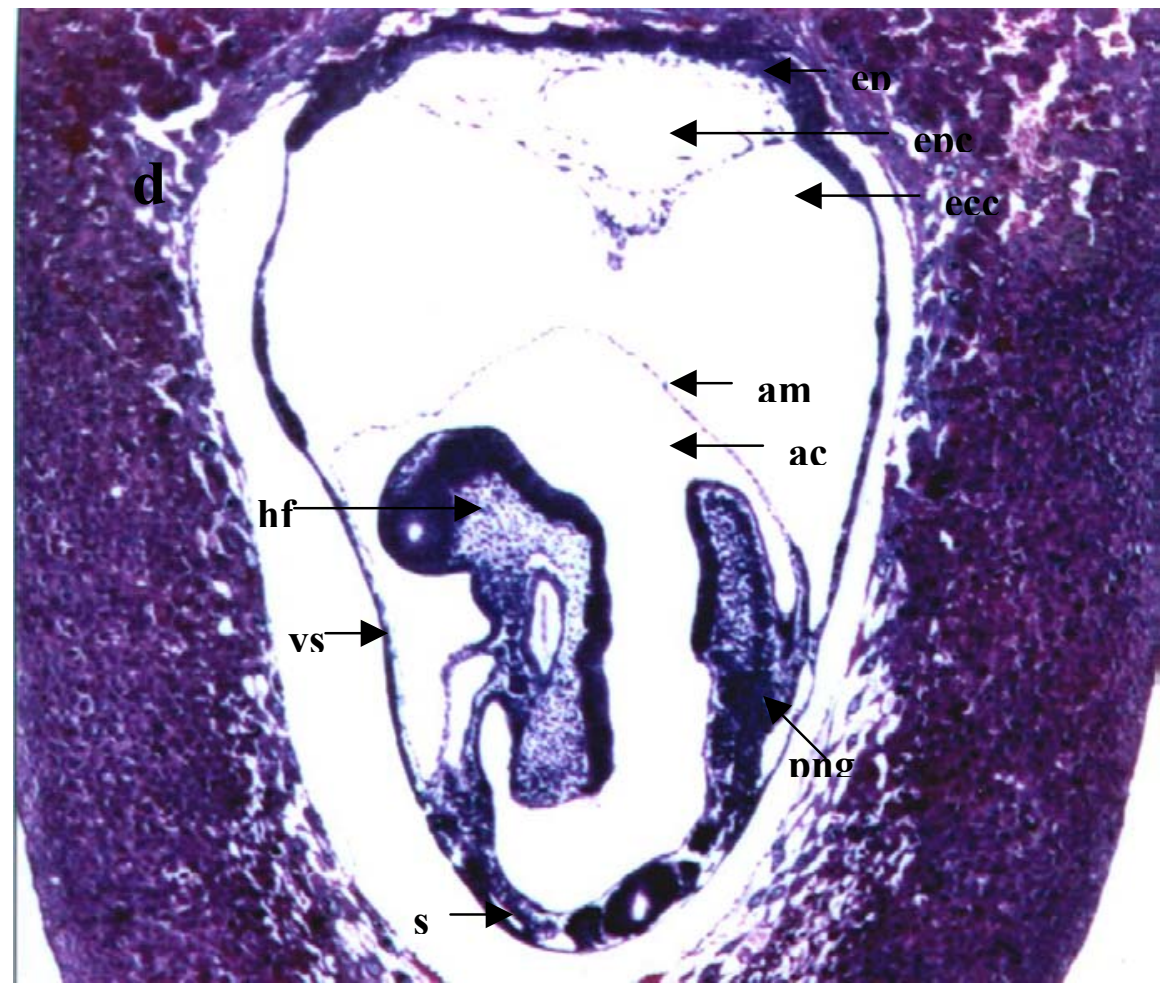

B

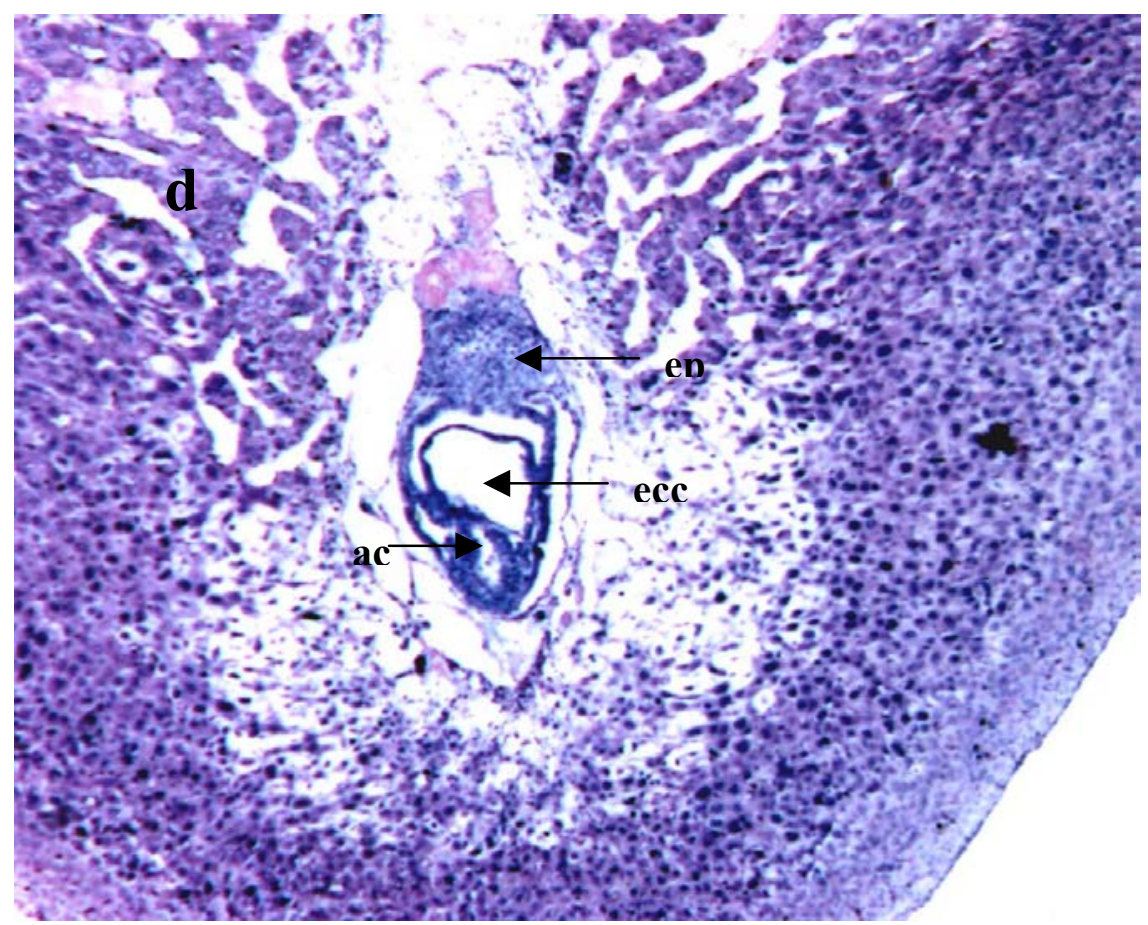

Figure 3.18: Histological analysis of a pelota mutant embryo and its wild-type or heterozygous littermate at E8.5. (A) Wild-type embryo. (B) Mutant embryo is much smaller and resorbed. ep, ectoplacenta; epc, ectoplacental cavity; ecc, exocoelomic cavity; a, allantois; am, amnion; pe, parietal endoderm; ac, amniotic cavity; png, posterior neural groove; ys, yolk sac; hf, head fold; s, somites. (d) decidua. 


\subsection{Pelota mutation affects proliferation of inner cell mass of blastocysts in vitro}

The fact that differentiation of the three germ layers is initiated in the pelota ${ }^{-/-}$embryos suggests that the developmental arrest is not due to lack of differentiation, but rather results from a proliferation defect. To directly determine the growth capability of mutant pelota ${ }^{-/-}$ embryos, E3.5 blastocysts from heterozygous intercrosses were collected and cultured individually in 96 well plates for 7 days. The cultured embryos were photographed each day. After 7 days, the DNA of the embryos was extracted and their genotypes were determined by PCR assay (Fig. 3.19). After two days in culture, pelota ${ }^{+/+}$pelota $^{+/}$and pelota $^{-/-}$blastocysts hatched from the zone pellucida, implanted onto the tissue culture plastic and form a multi-component structure in which the inner cell mass (ICM) grows as mound on top of the extraembryonic (but embryonically derived) trophoblast cells

(Fig. 3.19 A, B). During the first 4 days in culture, the inner cell mass (ICM) of pelota ${ }^{-/-}$ blastocysts was indistinguishable from that of pelota $^{+/+}$and pelota ${ }^{+/}$. However, while the ICM cells of pelota $^{+/+}$and pelota ${ }^{+/-}$embryos continued to expand throughout the 7-day culture period, pelota ${ }^{-/-}$ICM cells failed to expand subsequent to day 4 and the embryos invariably died by day 6 in culture (Fig. 3.19 E, F). In contrast, pelota ${ }^{-/-}$trophoblast giant cells (TGC) remained attached to the culture dish and continued to grow in size through 7 days of culture. Trophoblast giant cells are derived from cells that became mitotically inactive at about E4.5 and undergo repeated rounds of S-phase, generate polyploid nuclei and a large cytoplasm (Rough, 1990). Genotyping of cultured embryos was performed by PCR reaction (Fig. 3.20). The PCR analysis revealed 5 of 34 cultured embryos as pelota ${ }^{-/-}$ (Table 3.1). All blastocysts for which the growth of their inner cell mass was arrested after four days of culture were found as pelota ${ }^{-/}$.

The survival of mitotically inactive pelota $^{-/-}$trophoblast gaint cells and the death of mitotically active inner cell mass of pelota $^{-/-}$blastocysts support our hypothesis that pelota is required during mitosis.

\subsection{Pelota is required for progress of the mitotic cell cycle}

In Drosophila, the mitotic division appears to progress normal in homozygous mutants for pelota. In contrast, meiotic cell cycle of spermatogenic cells is arrested during the $\mathrm{G}_{2} / \mathrm{M}$ transition of the first meiotic division. The duplication of DNA content during the S-phase and failure of chromosomes to segregate in the arrested cells during M-phase result in 4n 
germ cells. To demonstrate that the pelota ${ }^{-/-}$cells of inner cell mass of cultured E6.5 and of E7.5 had passed through S-phase, DNA ploidy analysis with CAS imaging system was performed. More than $90 \%$ of cells dissociated from 6 blastocysts, which are collected from heterozygous intercrosses and cultured for 2 days, displayed 2n DNA content, whereas $30-40 \%$ of analysed cells from 2 embryos exhibited 4n DNA contents (Table 3.4). It was difficult to determine the genotype of these cultured cells of blastocysts.

To analyse the DNA contents in embryonic cells of E7.5, sections of 8 developmentally delayed embryos (mutant) and 10 control embryos were subjected to CAS image analysis (Fig. 3.21 A, B). 19-51\% of analysed cells in developmental delayed E7.5 displayed 4n DNA content, whereas $0-12 \%$ of analysed cell in control embryos were polyploid (Table 3.5). Statistical analysis indicates that the ratio of DNA ploidy of cells in developmentally delayed embryos was significantly different from that in control embryo. These data suggest that the deficiency of pelota results in a cell cycle arrest at the G2/M transition.

To support this hypothesis, mitotic spreads were prepared from blastocysts grown for 2 days in culture and then treated with nocodazole for $6 \mathrm{hr}$ to disrupt spindle microtubules. In these experiment, 8-12 metaphases/embryos could be examined in each blastocyst. In mitotic spread of two embryos, 3-4 metaphases contained 80 chromosomes (Fig. 3.22 B), while the rest of examined metaphases contained approximately 40 chromosomes (Fig. 3.22 A). In contrast, all examined metaphases in mitotic spread of 11 normal embryos contained a diploid number of 40 chromosomes. 

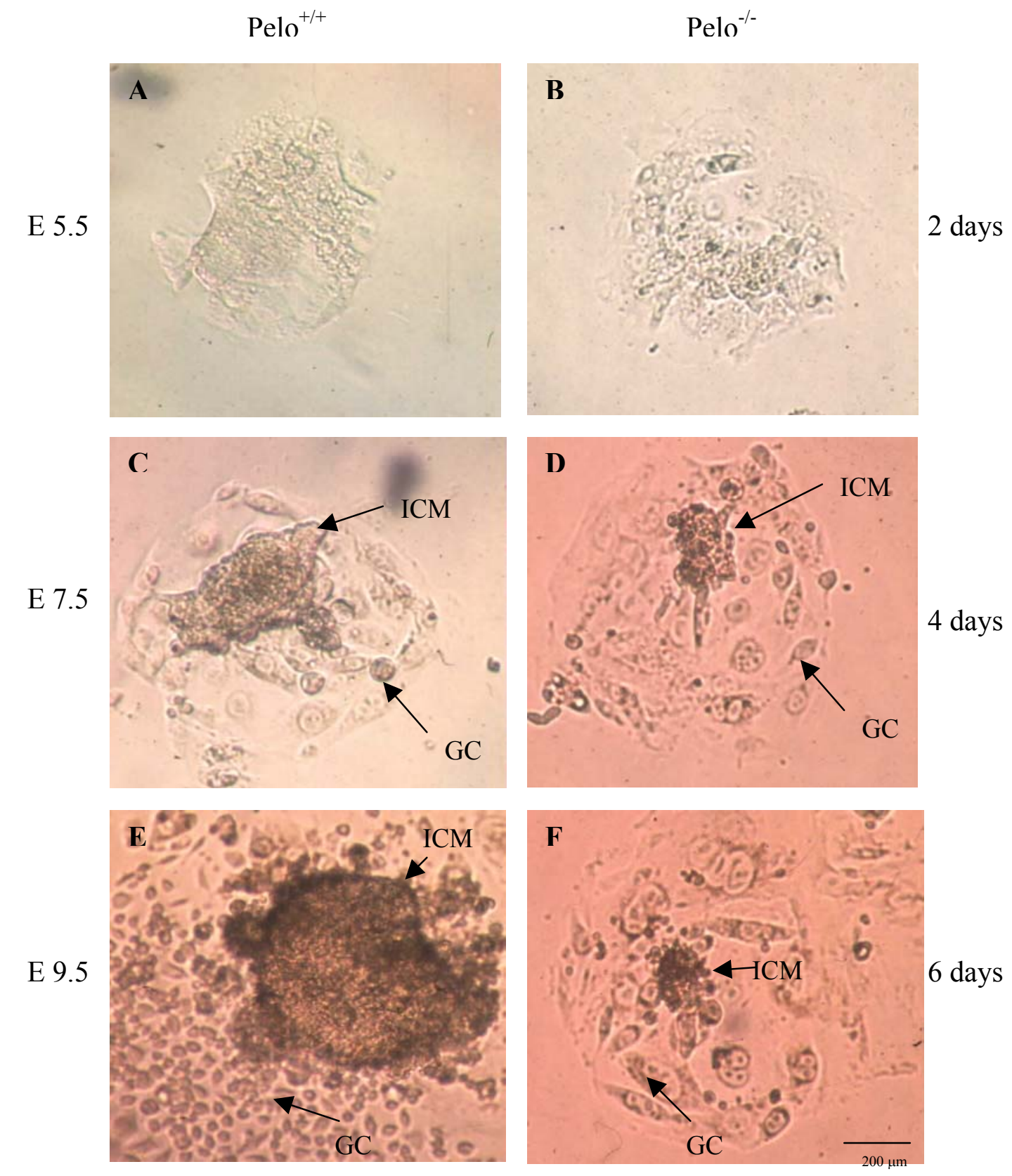

Figure 3.19: Growth of wild-type and pelo ${ }^{-/}$embryos in culture. E3.5 blastocysts from pelota heterozygous intercrosses were cultured in vitro for six days and photographed using phase contrast microscopy each day. A, B blastocysts were cultured for $48 \mathrm{hr}$ (E5.5); C, D, blastocysts were cultured for 4 days (E7.5); E, F, blastocysts were cultured for 6 days (E9.5). Arrows point to the inner cell mass (ICM) and to the trophoblast giant cells (TGC). Genotypes were determined by PCR. 


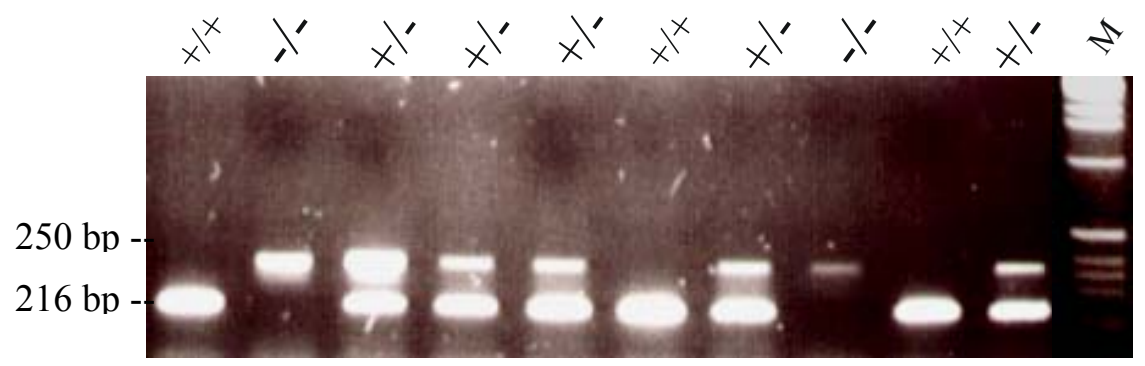

Figure 3.20: PCR genotyping of cultured embryos. At E9.5 in culture, DNA was extracted from individual cultures. PCR reactions were performed to amplify the wild-type allele (250 bp) and disrupted allele (216 bp) and the samples were then analysed on ethidium bromide-stained agarose gel. " $\mathrm{M}$ " indicates molecular weight markers.

Table 3.4: DNA content in cultured cells of E5.5 recovered from pelota heterozygous intercrosses.

\begin{tabular}{lllll}
\hline $\begin{array}{l}\text { Embryo } \\
\text { Number }\end{array}$ & $\begin{array}{l}\text { Total number } \\
\text { of cells }\end{array}$ & $\begin{array}{l}\text { Diploid } \\
\text { cells } \%\end{array}$ & $\begin{array}{l}\text { Polyploid } \\
\text { cells \% }\end{array}$ & $\begin{array}{l}\text { Ploidy- } \\
\text { state }\end{array}$ \\
\hline & 10 & 20 & 80 & polyploid \\
1 & 10 & 92 & 08 & $\begin{array}{l}\text { diploid } \\
\text { diploid }\end{array}$ \\
2 & 06 & 85 & 15 & diploid \\
3 & 16 & 100 & 00 & diploid \\
4 & 03 & 100 & 00 & diploid \\
5 & 08 & 99 & 01 & diploid \\
polyploid
\end{tabular}


$\mathbf{A}$

Distribution of DNA Mass

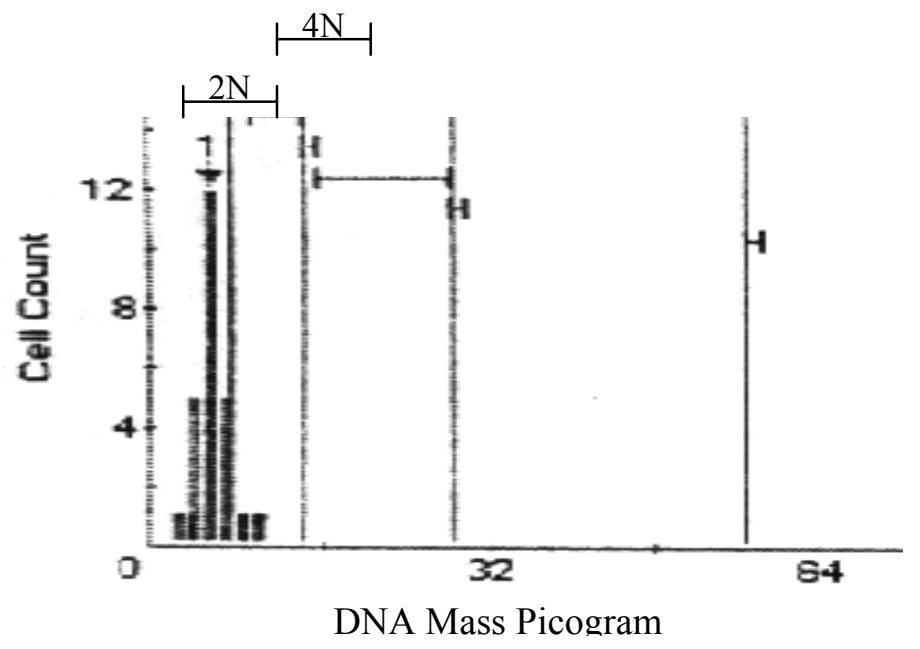

Distribution of DNA Mass

B

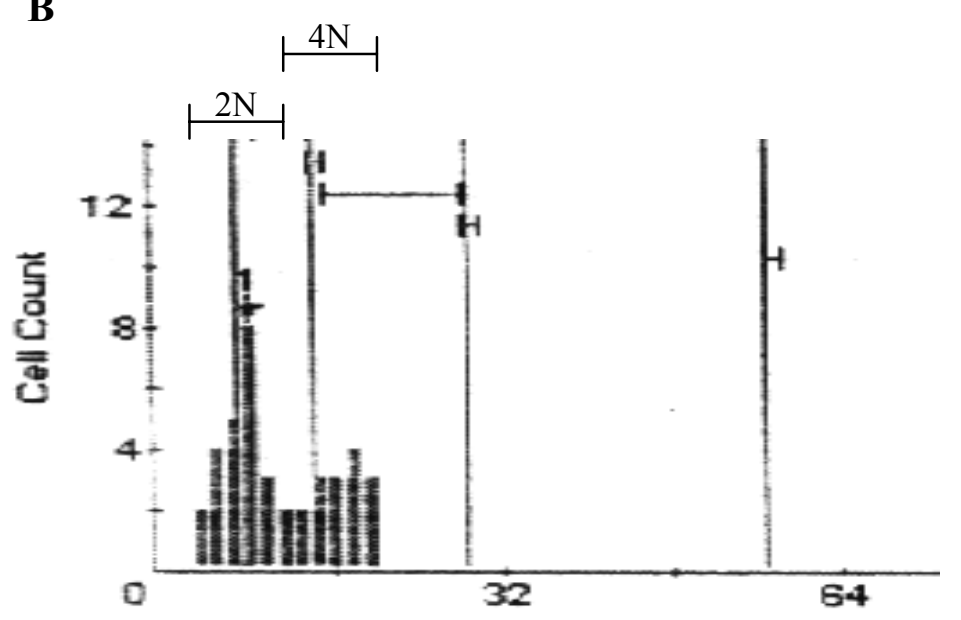

DNA Mass Picogram

Figure 3.21: DNA content in cells of embryos at E7.5. The DNA ploidy of cells of embryos was analysed by Feulgen staining and CAS image analysis. (A) Distribution of DNA in cells of wild-type blastocysts; (B) Distribution of DNA in cells of a mutant embryo which contains $30 \%$ of tetraploid cells. 
Table 3.5: DNA content in cells of embryos at E7.5 recovered from pelota heterozygous intercrosses.

\begin{tabular}{llllll}
\hline $\begin{array}{l}\text { Embryo } \\
\text { number }\end{array}$ & $\begin{array}{l}\text { Total number } \\
\text { of cells }\end{array}$ & $\begin{array}{l}\text { Diploid } \\
\text { cells } \%\end{array}$ & $\begin{array}{l}\text { Polyploid } \\
\text { cells } \%\end{array}$ & $\begin{array}{l}\text { Ploidy- } \\
\text { state }\end{array}$ & $\begin{array}{l}\text { Phenotype } \\
\text { of embryo. }\end{array}$ \\
\hline & & & & Polyploid & Abnormal \\
1 & 80 & 80 & 20 & Polyploid & Abnormal \\
2 & 63 & 69 & 31 & Polyploid & Abnormal \\
3 & 49 & 67 & 33 & Polyploid & Abnormal \\
4 & 39 & 49 & 51 & Polyploid & Abnormal \\
5 & 63 & 77 & 23 & Polyploid & Abnormal \\
6 & 45 & 70 & 30 & Polyploid & Abnormal \\
7 & 60 & 57 & 43 & Polyploid & Abnormal \\
8 & 11 & 81 & 19 & Diploid & Normal \\
9 & 49 & 100 & 00 & Diploid & Normal \\
10 & 44 & 91 & 09 & Diploid & Normal \\
11 & 31 & 88 & 12 & Diploid & Normal \\
12 & 80 & 96 & 04 & Diploid & Normal \\
13 & 71 & 97 & 03 & Diploid & Normal \\
14 & 103 & 100 & 00 & Diploid & Normal \\
15 & 25 & 99 & 01 & Diploid & Normal \\
16 & 76 & 98 & 02 & Diploid & Normal \\
17 & 35 & 91 & 09 & Diploid & Normal \\
18 & 4 & 96 & 04 & & \\
\hline
\end{tabular}



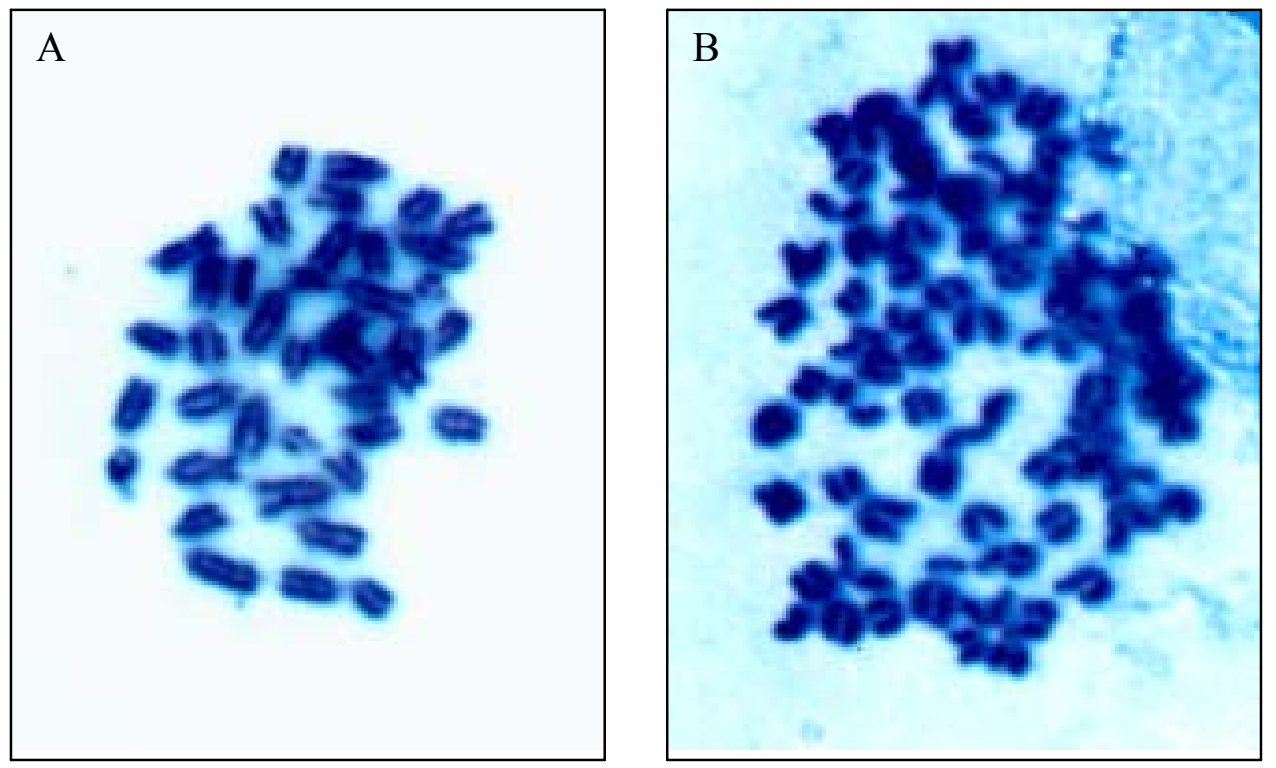

Figure 3.22: Metaphase spreads of cells derived from blastocysts cultured for two days. (A) diploid cell; (B) tetraploid cell. Magnification x650. 


\subsection{Pelota protein is associated with the centrosome}

The high rate of polyploidy seen in cells of the pelota deficient E7.5 suggests that loss of pelota protein leads to disruption either in kinetochore assembly structure, in centrosome or in microtuble formation. These cellular structures are involved in chromosome segregation. To address this question, subcellular localization of pelota protein was determined by establishing stable transfected ES-clones that constitutively express green fluorescent protein (GFP)-targeted pelota.

\subsubsection{Construction of a GFP-pelota plasmid}

To construct a green fluorescence/pelota (GFP-pelota) expressing plasmid, a fragment containing the cDNA nucleotide sequence with an artificial XhoI site at 5' end and a SmaI site at the 3' end was amplified by PCR using the human pelota cDNA as template. The amplified fragment was double digested with XhoI and SmaI and subcloned into the plasmid $p E G F P-C 1$ to produce $p G F P$-pelo (Fig. 3.23). The nucleotide sequence of this construct was confirmed by sequencing.

\subsubsection{Transfection of 3T3 fibroblast cell with the pGFP-pelo and subcellular localisation of the GFP-fluorescence signal in transfected cells}

The $3 \mathrm{~T} 3$ fibroblast cells grown on glass slides were transfected with $2 \mu \mathrm{g}$ of the $p$ GFP-pelo plasmid as described in (2.2.20.1). The cells were fixed with methanol and examined by Olympus BX60 microscope. The microscopic examination of the transiently transfected $3 T 3$ cells revealed that the green fluorescent protein (GFP)-targeted pelota is distributed in the cytoplasm (Fig. 3.24). The examination of the nuclear morphology in transfected cells by DAPI counterstaining revealed that all of these cells were in interphase. 
A- Pelota-cDNA

$\mathrm{Xh}$ $\mathrm{Sm}$

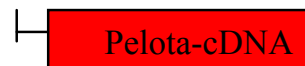

B- $p E G F P-C 1$

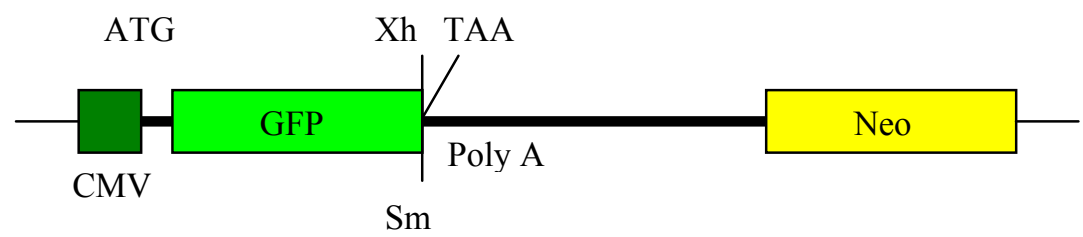

C- GFP-Pelota-Fusion

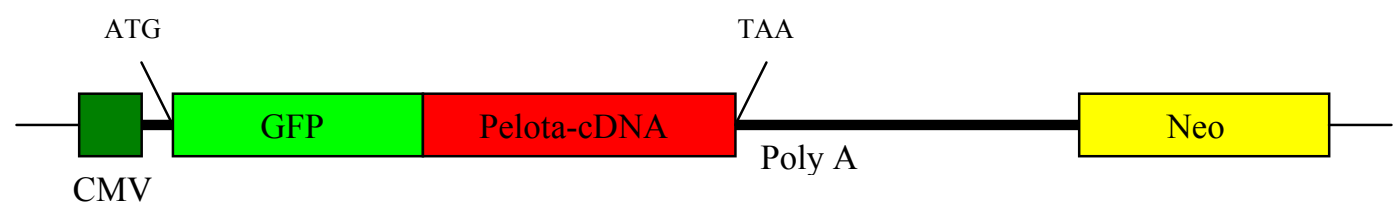

Figure 3.23: Strategy to subclone the pelota-cDNA in the pEGFP-C1 vector. (A) The human pelota cDNA fragment was amplified using the primer pECFP-C1F, which contains the sequence of the restriction site XhoI at the 3' end and the primer pECFP-C1R containg the sequence of the restriction site SmaI at the 5' end. The $980 \mathrm{bp}$ amplified product was digested with the XhoI/SmaI and subcloned into XhoI/SmaI digested pEGFPC1 vector. (B) Structure of the pEGFP-C1 vector. (C) GFP-pelota-fusion construct. Xh, XhoI ; Sm, SmaI, ATG, start codon; TAA, stop codon, CMV, Human cytomegalovirus promoter; Neo, Neomycin resistance gene. 
A

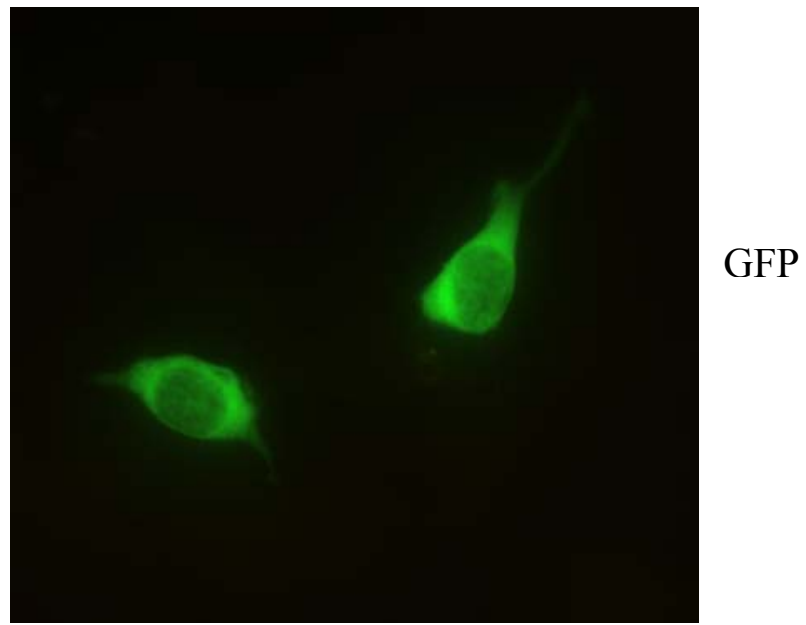

B

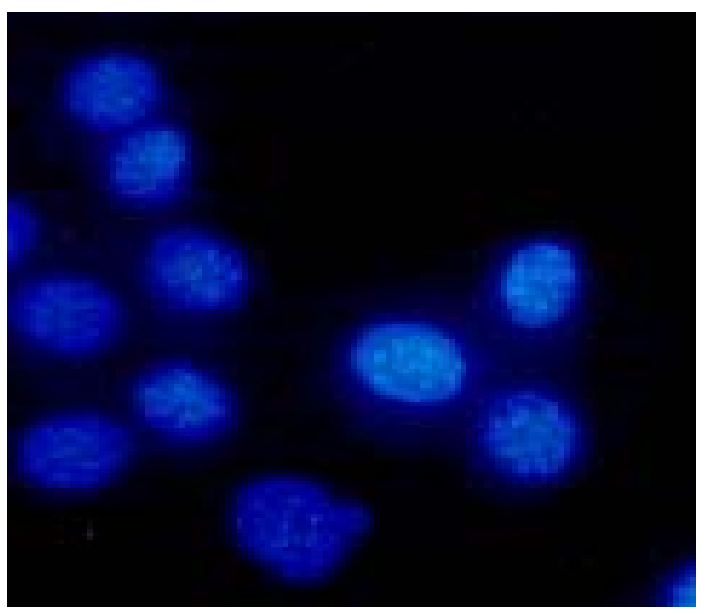

DAPI

C

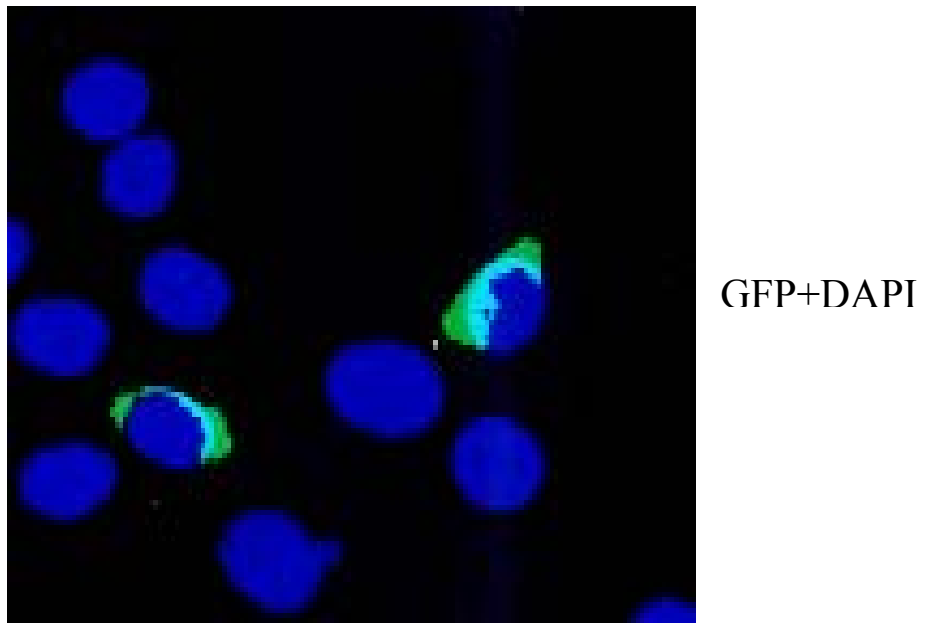

Figure 3.24: Transfection of fibroblast cells with GFP-pelota-fusion construct. (A) DAPI staining of nuclei of transfected fibroblast cells (all the nuclei show blue colour). (B) GFP-pelota-fusion protein located in the cytoplasm of fibroblast cells. $5 \%$ of cells were transfected (green colour from GFP gene). (C) Overlay-images of DAPI staining for the nucleus and GFP-pelota in the cytoplasm in only $5 \%$ of the cells. 


\subsubsection{Transfection of the ES cells with the pGFP-pelota and selection of stable transfected ES cells}

To avoid potential abnormal localisation of GFP-pelota fluorescence signal due to overexpression of the GFP-pelota fusion protein in the transiently transfected cells, embryonic stem cells were transfected with the ApaLI linearized pGFP-pelota construct by elecroporation. GFP-pelota expressing clones were initially isolated by G418-resistance selection. Of these clones, those were selected for the expression of the GFP-pelota fusion gene that yield a sufficient GFP-fluorescence signal. Three of these clones appeared to be stable after 10 passages in the absence of G418. This strategy enabled us to study the subcellular localization of GFP-pelota fusion protein during the cell cycle. Microscopical examination of the transfected ES cells showed that GFP-fluorescence is localised in a single dot directly adjacent to the nucleus of the prophase (Fig. 3.26 B). In metaphase, the GFP-fluorescence signal was decorated at both poles of the cell (Fig. 3.28 B). This pattern of localization of the GFP-fluorescence signal in the GFP-pelota transfected cells suggests that the GFP-pelota fusion protein is associated with the centrosome. The GFPpelota fusion protein was not only localised at centrosomes, but was also distributed uniformly over the cytosol (Fig. 3.28 B). To confirm the localization of the GFP-pelota at centrosomes, immunostaining of the GFP-pelota transfected ES cells with monoclonal anti $\gamma$-tubulin was performed. As shown in figures 3. 25, 3. 26, 3. 27 and 3.28 the $\gamma$-tubulin could be co-localized exactly with the GFP-fluorescence signal in interphase, prophase and metaphase. These results indicate that the pelota protein is associated with the centrosomes. 

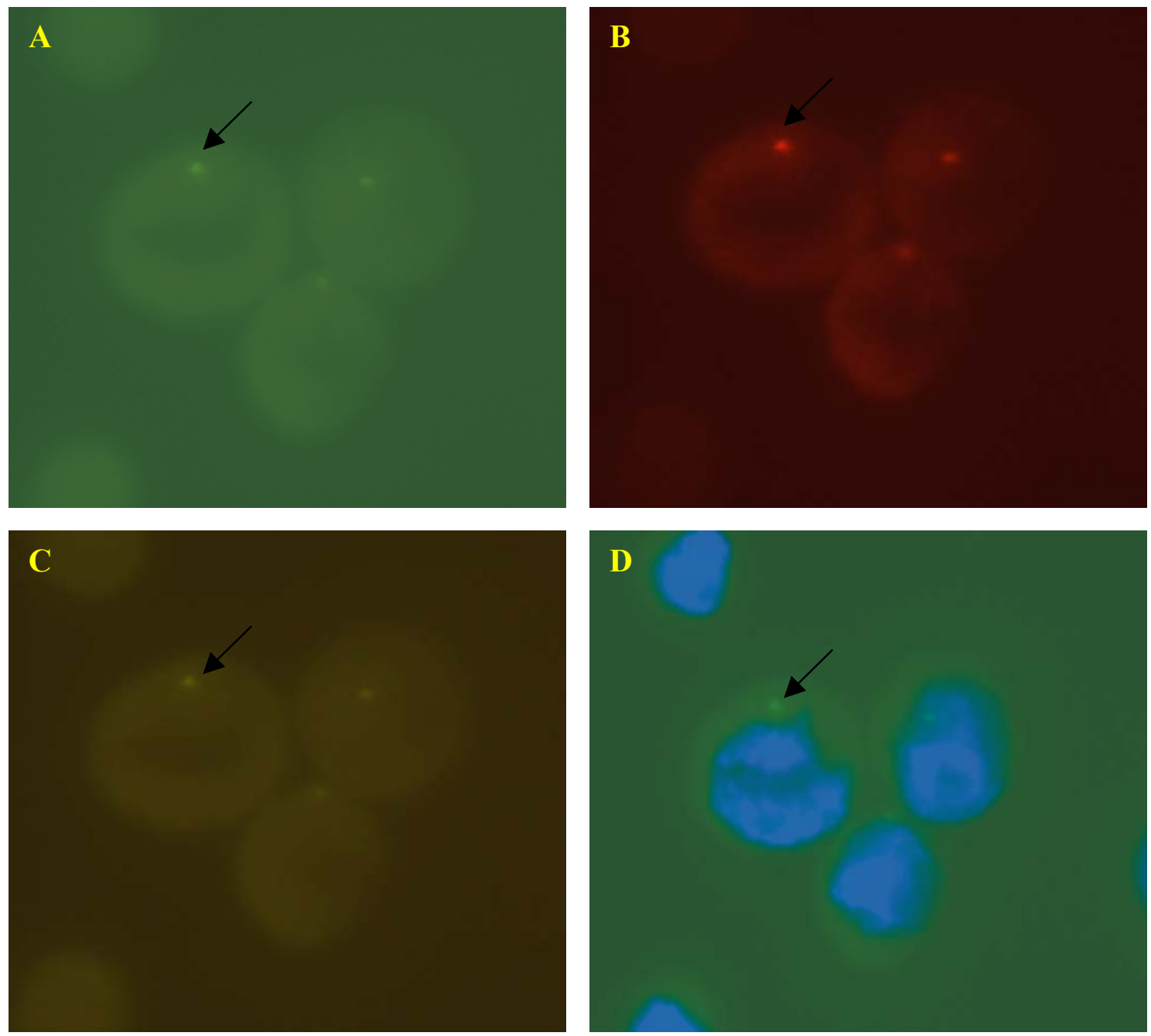

D

$\mathbf{E}$

Figure 3.25: Immunofluorescent localization of GFP-pelota protein in transfected ES cells. Interphase cells showing GFP-pelota (green), $\gamma$-tubulin (red), and DNA (blue). (A) Localization of GFP-Pelota proteins in the centrosome (B) Immunfluorescent staining of GFPpelota-recombinant ES cells with anti- $\gamma$-tubulin. (C) The co-localization of $\gamma$-tubulin-staining with green fluorescent GFP-Pelota-signal. (D) Overlay-images of GFP-pelota protein for centrosome and DAPI-Staining. (E) Overlay images of $\gamma$-tubulin and DAPI-staining. Arrows indicate centrosomes. 

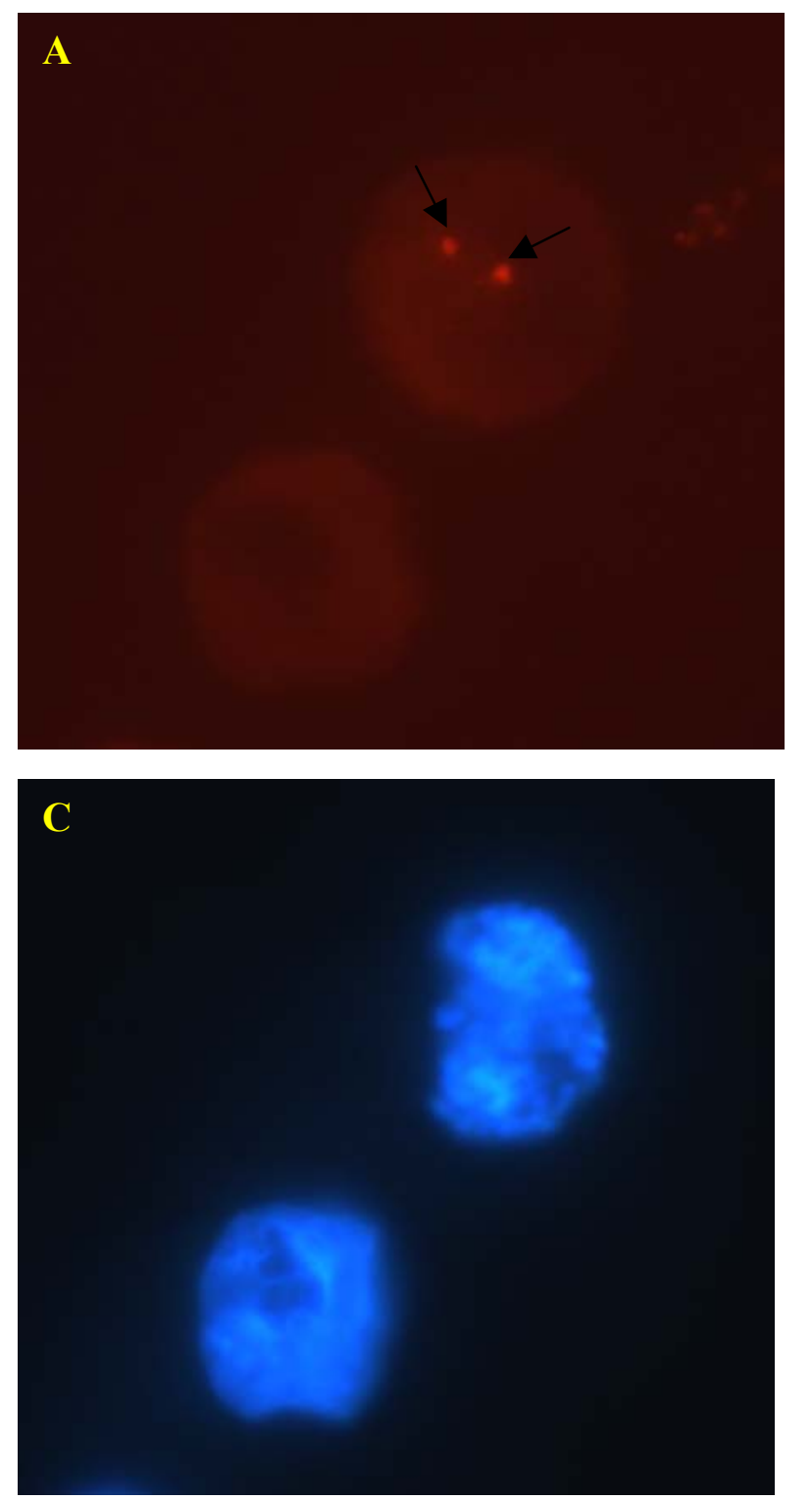

Figure 3.26: : Immunofluorescent localization of GFP-pelota protein in transfected ES cells. Prophase cells show the two centrosomes adjacent to the nucleus. (A) Immunofluorescent staining of GFP-pelota-recombinant ES cells with anti- $\gamma$-tubulin (red). (B) Localization of GFP-pelota proteins in the centrosome. (C) DAPI-staining for DNA. Arrows indicate centrosomes. 


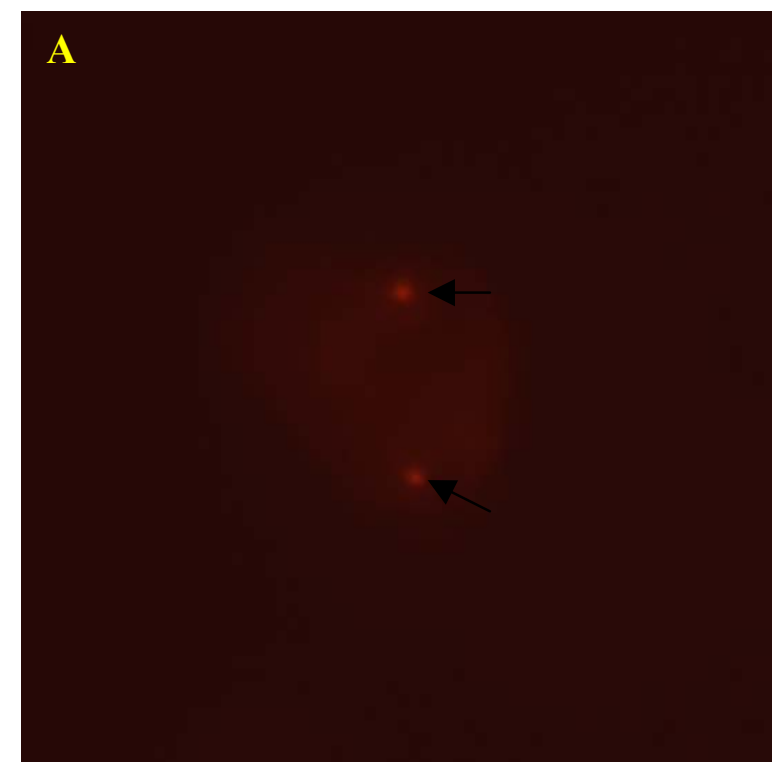

\section{B}
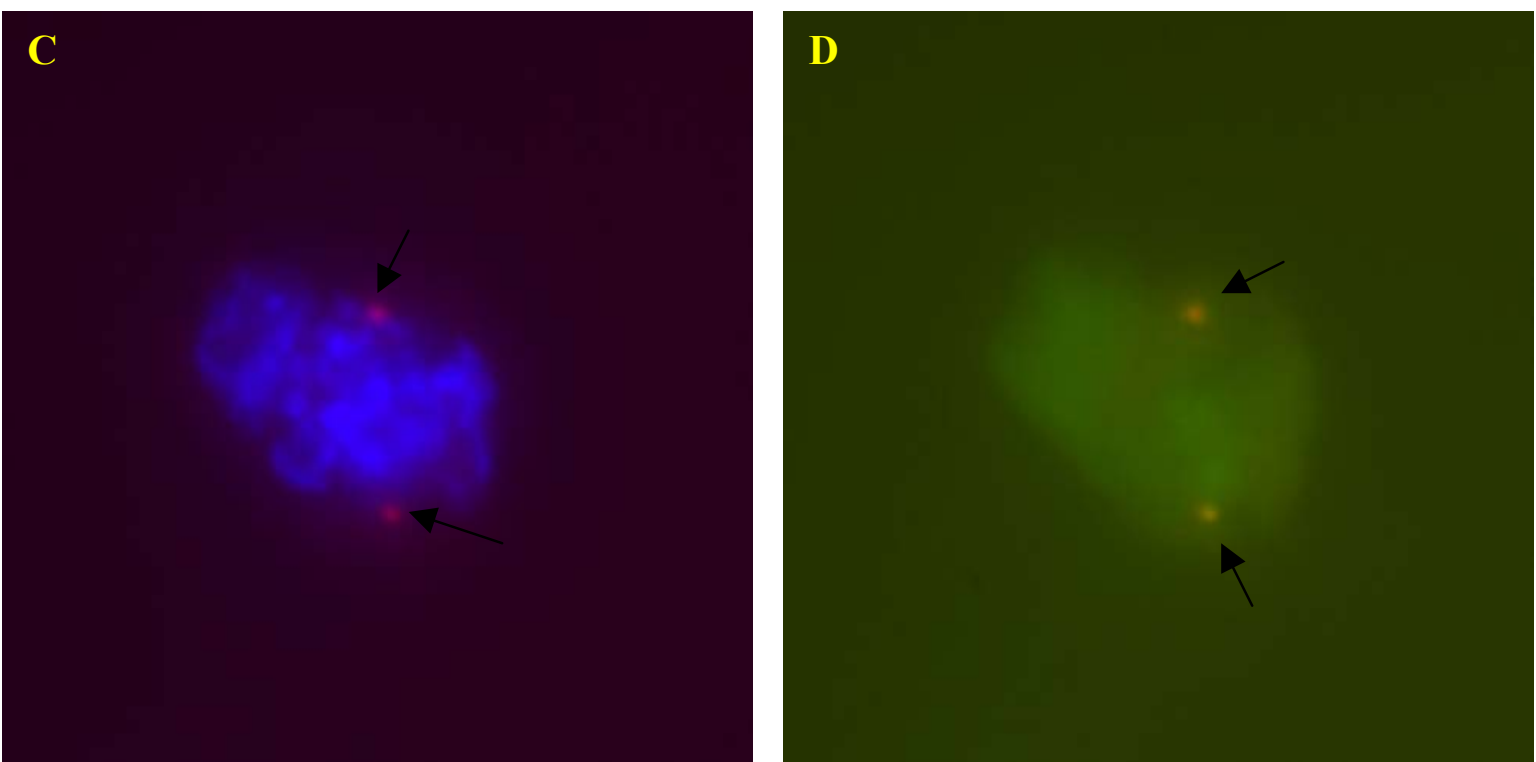

Figure 3.27: Transfection of ES cells with GFP-pelota-fusion construct. Prophase cells show the two centrosomes (A) Immunfluorescent staining for GFP-pelota-recombinant ES cells with anti- $\gamma$-tubulin (red). (B) Overlay images of green fluorescent of GFP-pelota protein in centrosome and DAPI-staining for DNA (blue). (C) Overlay images of anti- $\gamma$-tubulin and DAPIstaining. (D) The co-localization of $\gamma$-tubulin-staining with GFP-pelota-signal. Arrows indicate centrosomes. 

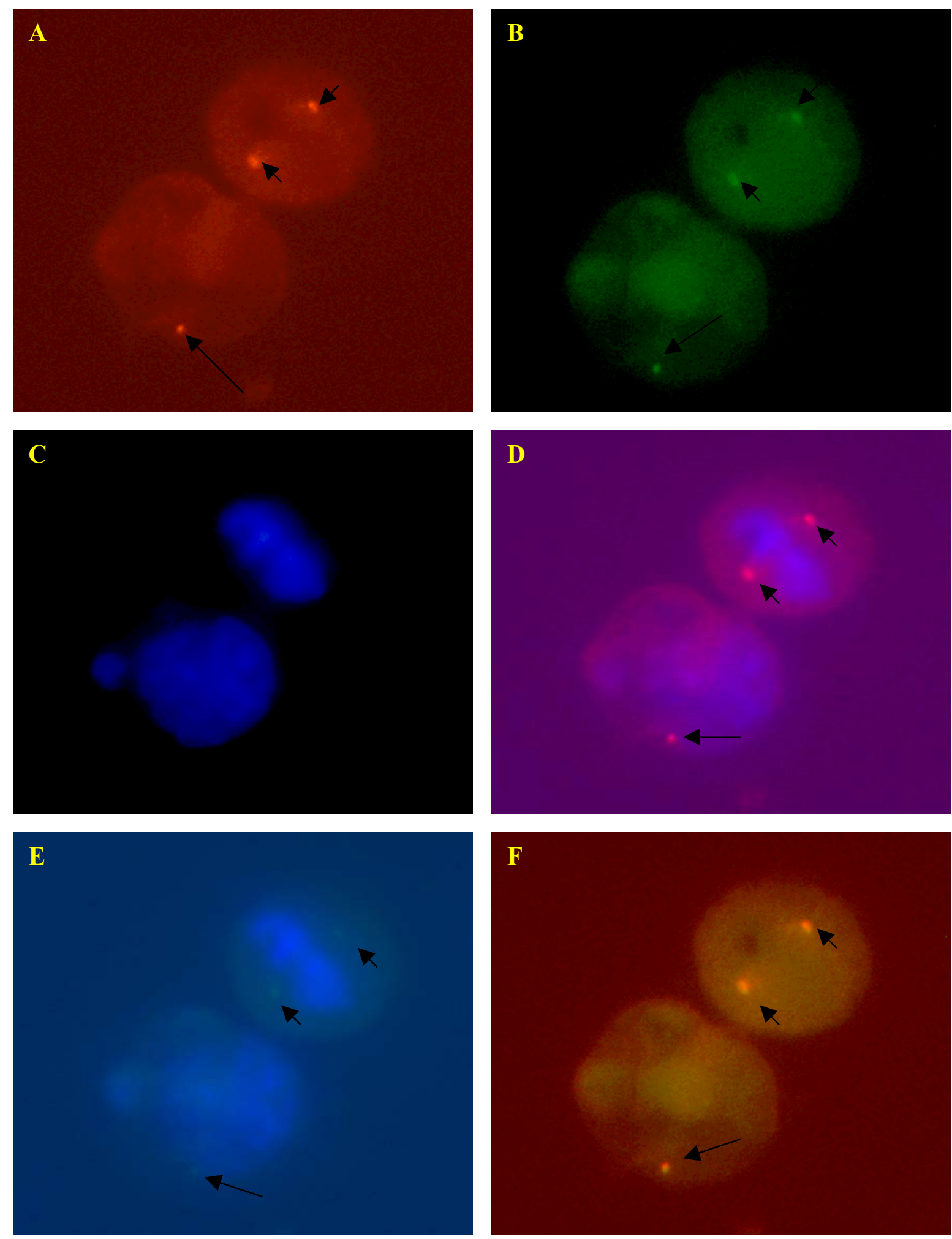

Figure 3.28: GFP-pelota-recombinant ES cells in metaphase and interphase stages. (A) Immunofluorescent staining with anti- $\gamma$-tubulin (red). (B) Localization of GFP-pelota proteins in the centrosome (green). (C) DAPI-staining for chromosomes (blue). (D) Overlay-images of $\gamma$-tubulin and DAPI-staining. (E) Overlay-images of GFP-pelota protein and DAPI-staining. (F) The colocalization of $\gamma$-tubulin-staining with GFP-pelota-signal. Short and long arrows indicate centrosomes in metaphase and interphase stages, respectively. 


\section{DISCUSSION}

\subsection{Pelota is highly conserved during evolution}

The pelota gene has been isolated and characterized in Archaebacteria Methanococcus jannaschii (Bult et al., 1996), Sulfolobus solfataricus (Ragan et al., 1996), in yeast Saccharomyces cerevisiae (Davis and Engebrecht, 1998), in worm Caenorhabditis elegans (Gen Bank, Accession No. Z36238), in plant Arabidopsis thaliana (Gen Bank, Accession No. T20628), in human (Shamsadin et al., 2000) and in mouse (this work). Comparison of the predicted amino acid sequence of pelota from the seven species reveals a high level of sequence conservation (Fig. 4.1). The sequence identity ranges from $31 \%$ between mouse and $S$. cerevisiae and 95\% between mouse and human (Table 4.1). Considering conservative changes of the amino acid, the overall similarity between mouse and human reaches to $98.5 \%$. The seven predicted proteins have start and stop codons in similar locations, with the exception of a small extension in N-terminal of $S$. cerevisiae predicted protein. Homology between the proteins was distributed across the entire protein.

The PROSITE protein motif library failed to reveal major structural motifs indicating a particular biological function for the pelota protein. However, numerous putative phosphorylation motifs were detected, spread across the length of the predicted protein, in the mammalian sequence. This includes motifs for protein kinase C, casein kinase II and tyrosine kinase phosphorylation sites. Furthermore, two N-glycosylation and three $\mathrm{N}$-myristoylation sites were detected in the mammalian proteins. It is currently unknown which of these putative motifs are physiologically significant for posttranslational modifications. Davis and Engebrecht (1998) reported that the pelota of S. cerevisiae contains three regions that display similarity to conserved motifs: (1) A putative nuclear localization signal (NLS) is located at residues 173-177 of the yeast protein. This sequence PKKKR is similar to PKKKRK of simian virus 40 (SV40) large T antigen. (2) Residues 267-323 are highly similar to a protein of eukaryotic peptide chain release factor subunit I (ERFI). The ERFI family of protein is involved in the termination step of protein synthesis (Frolova et al., 1994). (3) A putative leucine zipper motif is located at the C-terminus of $S$. cerevisiae protein. Leucine zippers have been suggested to mediate protein-protein 
interactions in a diverse set of functionally unrelated proteins (Busch and Sassone-Corsi, 1990). Alignment of seven proteins (Fig. 4.1) revealed that the other pelota proteins share the NLS, ERFI and leucine zipper motifs.

The localization of the GFP-fluorescent signal in the centrosome of the GFP-pelota transfected ES-cells as well as localization of the GFP-fluorescence only in cytosol of the GFP-pelota transfected 3T3 cells rule out that the nuclear localization signal of the pelota protein is functionally relevant. All pelota proteins contain 2-4 leucine zipper motifs. Therefore, it is important to address, whether the leucine zipper motifs are involved in dimerization of the pelota with other proteins and to identify the protein partners of pelota. This question can be addressed using the method of yeast two hybrid system.

A phylogenetic analysis of pelota primary amino acid sequences from different species using the distance matrix program, CLUSTALW (Higgins et al., 1992) is shown in figure 4.2. The degree of sequence similarity is entirely congruent with the evolutionary relationship of the respective organisms. This is in support of the idea that the pelota genes are all derived from the same ancestral gene. 


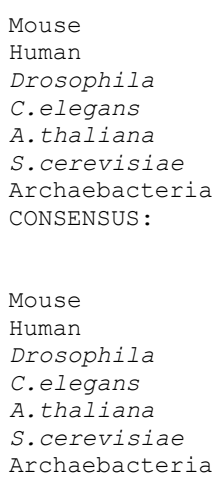

--MKLVRKDIEKDNAGQVTLVPEE PE DMWHTYNLVQVGDSLRASTIRKVQTESSTGSVGS 58 --MKLVRKNIEKDNAGQVTLVPEEPEDMWHTYNLVQVGDSLRASTIRKVQTESSTGSVGS 58 --MKLLGKYVDKGMQGNVTLVPEESEDMWHAYNLIAKGDSVRSTTIRKVQNFTATGSSTS 58 --MKQFKR IERDGTGFVVLMAEEAEDMWHI YNLIRIGDI IKASTIRKVVSETSTGTTSS 58 --MKIVRRDFVRNGPGSVKMVAEDSDDLWYAYNLIAVGDSVMAVTFRKVOREIPGGGRDS 58 MKVISLKKDSFNKGGAVITLLPEDKEDLFTVYQIVDKDD--ELIFKKKFTSKLDEAGKKK 58 --MKIIEE I PQKN---IIKLMPENLDDLWVLYNI IEEGDKIFAVTERRVQDKGDVIRADR 55 KLVRK IEK G VTLVPEE EDMWH YNLI VGDSLRASTIRKVQTES TGS S

$$
\text { ILK VD } \quad \text { I } \quad \text { IK T } \quad \text { S T }
$$

-NRVRTTLTLCVEAIDFDSQACQLRVKGTNI QE-----KEYVKMGAYHTIELE PNRQFTL 112 -NRVRTTLTLCVEAIDF DSQACQLRVKGTNIQE-----NEYVKMGAYHTIELE PNRQFTL 112 -SFVRTTLTIAVES IDFDTQACVVRLKGRNIEE-----NQYVKMGAYHTLDLELNRKFEL 112 -ORVHTMLTVSVES IDFDPGAOELHLKGRNIEE-----NDIVKLGAYHTIDLEPNRKFTL 112 -ERVKLKLEVQVEEVDYDKDGSVLRIRGKNILE-----NEHVKIGAFHTLELELKRPFVL 112 -STDLVKLKIKVISEDFDMKDEYLKYKGVTVTDESGASNVDIPVGKYLSFTLDYVYPFTI 117 GAKRKMFLGIEVKNVEFDENTKRVRILGTIIHG-----PDDVPLGSHHTIEIKPFDELSI 110 RVRT LTL VE IDFD QA LRVKG NI E NE VKMGAYHTIELEPNR FTL

$$
\begin{array}{lllllll}
\mathrm{K} & \mathrm{I} & \mathrm{N} & \mathrm{L} & \mathrm{D} & \mathrm{L}
\end{array}
$$

AKKQWDSVVLERFEQACDPAWSADVAAVVMQEGLAHVCLVTPSMTLTRAKVEVNIPRK-R 171 AKKQWDSVVLER IEQACDPAWSDDVAAVVMQE GLAHICLVTPSMTLTRAKVEVNIPRK-R 171 RKPEWDTIALERIEMACDPTOSADVAAVVMOEGLAHVCLITASMTLVRSKIVESIPRK-R 171 OKTEWDSIDIERLNLALDPAOAADVAAVVLHEGLANVCLITPAMTLTRAKIDMTIPRK-R 171 RKEMWDSMALDTLKQASDPAASADLAVVLMQE $G$ LA $Q$ IFLVGRSVTSSRARIETSIPRK-H 171 IKQNFNKFMQKLLNEACNIEYKSDTAAVVLQEGIAHVCLVTSSSTILKQKIEYSMPKKKR 177 EKN-WKKWQIERIKEA IESSKRPKVLVVVMDDEEADIFEVRDYS IKEICSIKSHTSKK-- 167 $K$ WDSV LERI ACDPA SADVAAVVMQEGLAHVCLVT SMTLTRAKVE SIPRK R

$$
\text { I } \mathrm{L} \quad \mathrm{S} \quad \mathrm{I} T
$$

KGNCSQHDPALERFYEQVVQAIQRHINFEVVKCVLVASPGFVREQFCDYMFQQAVKTDNK 231 KGNCSQHDRALERFYEQVVQAIQRHIHFDVVKCILVASPGFVREQFCDYMFQQAVKTDNK 231 KGSVOOHEKGLAKFYEOVMOS ILRHVDFDVVKCVLIASPGFVRDQFYDYMFOOAVKMDYK 231 KGFTSOHEKGLEKFYEAVSTAFMRHVNLOVVKCVIVASRGFVKDAFMOHLIAHADANGKK 231 GPAIAGYESALKKFFENVLQAFVKHVDFSVVRCAVVASPGFTKDQFHRHLLLEAERRQLR 231 TTDVLKFDEKTEKFYKAIYSAMKKDLNFDKLKTIILCSPGFYAKILMDKIFQYAEEEHNK 237 -----LDYK INEELKKEYYHEIAKVLSEYDVDNILVAGPGFAKNSFYNFISSQYPELKNK 222 KG QHD ALEKFYEQVVQAI RHV FDVVKCVLVASPGFVRDQF D MFQQA K NK

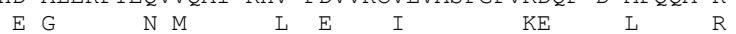

VLLENRSKFL-VHASSGHKYSLKEALCDPTVASRLSHTKAAGEVKALDDFYKMLQHEPDR 290 LLLENRSKFLQVHASSGHKYSLKEALCDPTVASRLSDTKAAGEVKALDDFYKMLQHEPDR 291 LLLDNKSKFMLVHASSGFKHSLREILQDPAVLAKMSDTKAAGEVKALEQFYMMLQCEPAK 291 FTTEORAKFMLTHSSSGFKHALKEVLETPOVALRLADTKAOGEVKALNOFLELMSTEPDR 291 PIIENKSR I ILVHTNSGYRHSLGEVLHAPNVMNMIKDTKAAKEVKALNDFHNMLSTEPDR 291 KILDNKGMF F IAHCSTGYLQGINEVLKNPLYASKLQDTKYSKEIMVMDEFLLHLNKDDDK 297 IVVES--------ISTTSRAGLNEVIKRG I INRIYAESRVAKETQLIEKLLEE IAKKG-L 273 LLLENRSKFLLVH SSG K SLKEVL P VA RL DTKAAGEVKALDDF MLQ EPDR $\begin{array}{llllll}\text { VVV } & \mathrm{K} & \mathrm{MI} & \mathrm{R} & \mathrm{K} & \mathrm{E}\end{array}$

AFYGLKQVERANEALAIDTLLISDELFRHQDVATRSRYVRLVDSVKENAGTVRIFSSLHV 350 AFYGLKQVEKANEAMAIDTLLISDELFRHQDVATRSRYVRLVDSVKENAGTVRIFSSLHV 351 AFYGKKHVLOAAECOAIETLIISDNLFRCODVSLROEYVNLVESIRDAGGEVKIFSSMHI 351 AFYGFNHVNRANQELAIETLLVADSLFRAQDIETRRKYVRLVESVREQNGKVHIFSSMHV 351 ACYGPKHVEVANERMAIQTLLITDELFRNSDVKTRKKYVNLVESVKDSGGDAFIFSAMHV 351 AWYGEKEVVKAAEYGAISYLLLTDKVLHSDNIAQREEYLKLMDSVESNGGKALVLSTLHS 357 AVYGIDEVKKALEYSAIDTLLVSDSLVRNHEIEK------IIDTTEEMGGKVVIVSSEHD 327 AFYG $K V$ RANE LAIDTLLISD LFR QDV TR RYVRLVDSVKENGG VRIFSSMHV

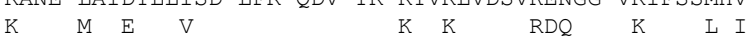

SGEQLGQLTGVAAILRFPVPELS------------------- 372

YGEOLSOLTGVAAILRFPVPELSDOEGDSSSEED--------- 385

SGEQLAQLTGIAALLRFPMPELEDSDDDDDEDGAAGGAADSDSD 395

SGEQLAQLTGCAAILRF PMPDLDDEPMDEN--.--_-.--- 381

SGEQLAQLTGIAALLRFPLPELEDIEM-------------- 378

LGEELDQLTGIACILKYPLPDLDEDDGEE-------------- 386

AGKOLKALGGIAGLIRFPIE---------------------- 347

SGEQLAQLTGIAAILRFPVPELED E D

$$
\text { G L KY M D } \quad \text { D } \mathrm{E}
$$

Figure 4.1: Alignment of the predicted amino acid sequence of mouse pelota with related sequences from other species. Numbers represent the amino acid number in the sequence. Hyphens indicate gaps introduced into the sequence to maximize alignment. Consensus indicates at least four amino acids with identical or similar residues at given position. Conserved residues are shown in boldface type. Conservative amino acids are grouped as follows: S, T; A, G; D, E; N, Q; H, R, K; I, L, V, M; F, W, Y, C; P. 
Table 4.1: Identity (\%) of the alignment of amino acid sequences of pelota from several species.

\begin{tabular}{|c|c|c|c|c|c|c|c|}
\hline & Mouse & Human & Drosophila & S.cerevisiae & A.thaliana & C.elegans & Archaebacteria \\
\hline Mouse & & 95 & 65 & 31 & 51 & 59 & 27 \\
\hline Human & & & 64 & 31 & 51 & 57 & 28 \\
\hline Drosophila & & & & 29 & 51 & 57 & 26 \\
\hline S.cerevisiae & & & & & 28 & 29 & 24 \\
\hline A.thaliana & & & & & & 48 & 27 \\
\hline C.elegans & & & & & & & 27 \\
\hline Archaebacteria & & & & & & & \\
\hline
\end{tabular}

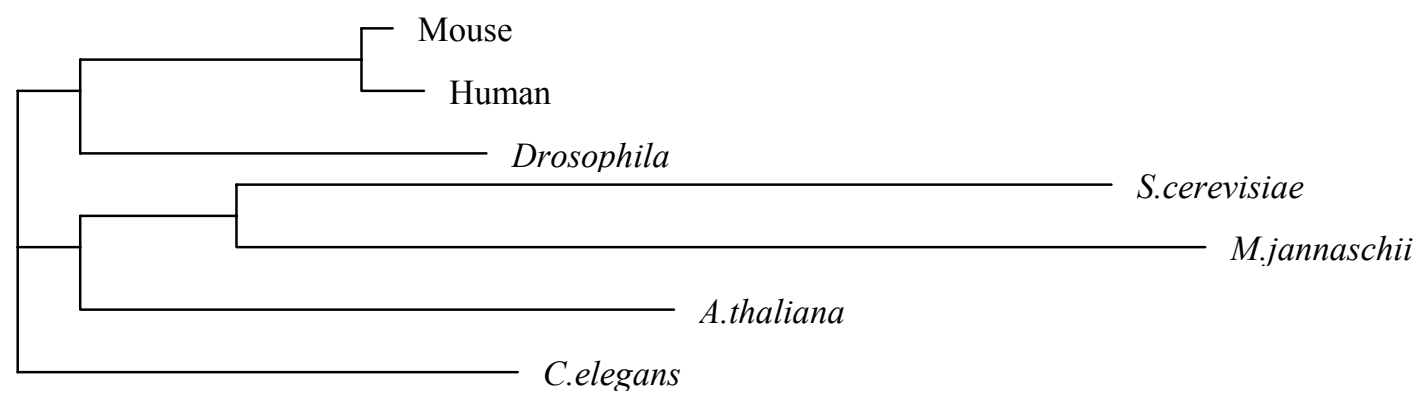

Figure 4.2: Phylogenetic tree of pelota for mouse, human, Drosophila, S.cerevisiae, Archaebacteria M.jannaschii, A.thaliana and C.elegans. The tree was constructed using the sequence data of the pelota listed in Figure 4.1. 


\subsection{Expression of the pelota gene during prenatal development and in different mouse} tissues

To obtain possible clue to pelota function, expression of the pelota gene was examined in embryos at different fetal stages and in different tissues of adult mouse. RT PCR analysis revealed that the pelota gene is expressed during prenatal development of mice (Fig. 3.2). A $1.6 \mathrm{~kb}$ pelota mRNA species was easily detected in all examined tissues (Fig. 3.1), indicating the constitutive expression of the pelota gene. Unlike the other tissues, a clear larger mRNA transcript $(2.1 \mathrm{~kb})$ was found in spleen (Fig. 3.1). In human the $2.1 \mathrm{~kb}$ pelota transcript was only detected in testis (Shamsadin et al., 2000). The length of the constitutive transcript is in good agreement with the length of mouse and human pelota cDNA $(1.6 \mathrm{~kb})$. The origin and significance of the $2.1 \mathrm{~kb}$ transcript detected in human testis and in mouse spleen remain to be determined. Analysis of expression of the pelota gene in Drosophila reveal that the transcript is $2.1 \mathrm{~kb}$ in length and is present in all developmental stages examined, but was most abundant in $0-2 \mathrm{hr}$ old embryos and in adults (Eberhart and Wasserman, 1995). The $2.1 \mathrm{~kb}$ transcript was detected in the germlineless progeny of oskar mutant flies and in $i a b$ mutant flies that lack a gonad. These results demonstrate that the pelota transcript is not restricted to the germline or gonad. Similar results were also found in mouse. The pelota transcript was detected in the testis of $\mathrm{W} / \mathrm{W}^{\mathrm{V}}$ mutant mice, which lack germ cells (Fig. 3.5).

\subsection{Mutation of the mammalian pelota gene results in early embryonic lethality}

The control of progression through the cell cycle in animal cells is complex with multiple control points that may vary depending on the lineage and developmental stage of cell (Kuerbitz et al., 1992; Sandell et al., 1993; Hardwick 1998; Chen et al., 1998; Taylor et al., 1998). Genes controlling cell cycle are generally conserved from human to yeast, including the human ATM, Chk1, Mad2 and pelota genes (Xu and Baltimore, 1996; Takai, et al., 2000; Doles, et al., 2000; Shamsadin, et al., 2000). Multiple mammalian homologues of the yeast cell cycle regulation genes have been found, each of which may function at specific stages of the cell cycle (review in Pines, 1993). However, the role of particular cell cycle genes may vary among species. For example, while the mutation in the pelota gene in Drosophila causes an arrest of cell cycle at the $\mathrm{G}_{2} / \mathrm{M}$ transition of the first meiotic division (Eberhart and Wassermann, 1995), mutation in the pelota homologue dom34 in 
$S$. cerevisiae shows that progression through the $\mathrm{G}_{1}$ phase of the cell cycle is delayed. Mutant cells enter meiosis aberrantly and their ability to form pseudohyphae is significantly diminished (Davis and Engebrecht, 1998).

In order to identify the role of the mammalian pelota gene, we have inactivated the pelota gene in mouse genome by replacing exon 2 and 3 by the bacterial neomycin gene (Fig. 3.9). Chimeric mice were successfully produced and transmitted the mutant allele to their progeny. Heterozygous pelota mice $\left(\mathrm{F}_{1}\right)$ were viable and fertile and show no apparent abnormalities in development or fertility. These observation indicates that one functional copy of the pelota gene is sufficient for normal development. However, when the heterozygous mice were intercrossed, no pelota homozygous mice could be found among 240 offspring, indicating that pelota deficiency results in embryonic lethality. To determine when pelota $^{-/}$embryo die, we analyzed embryos from heterozygous intercrosses at various points of gestation. At E8.5 - E12.5, none of examined embryos were pelota ${ }^{-/}$. At E2.5 and E3.5, pelota ${ }^{-/}$was detected in an expected ratio for a Mendelian distribution suggesting that pelota ${ }^{-/-}$embryos die between E3.5 and E8.5.

A normal mouse blastocyst attaches to the uterus between E4.5 and E5.0 (Rinkenberger, et al., 1997). Even embryos that die or are degraded shortly after attachment stimulate decidualization, a process whereby stromal cells expand, elaborate extracellular matrix and form tight junctions (Welsh, 1993). Histological sections of deciduas at E6.5 - E8.5 revealed no evidence of embryo resorption or empty deciduas at E6.5. All histological examined at E6.5 appeared to be normal. Examinations at E7.5, two phenotypes were obvious, one normal and one other abnormal. Smaller, poorly organized abnormal embryos could be readily distinguished among their wild-type littermates (Fig. 3.16). These results indicate that the pelota mutation affects the embryonic development before E7.5. At E8.5, phenotypic differences became even more apparent. The fact that differentiation of the three germ layers is initiated in the pelota $^{-/-}$embryos suggests that the developmental arrest is not due to lack of differentiation, but rather results from a proliferation defect.

Expression analysis showed that the pelota gene is ubiquitously expressed throughout development, including embryonic stem cells. However, no defects were observed in the

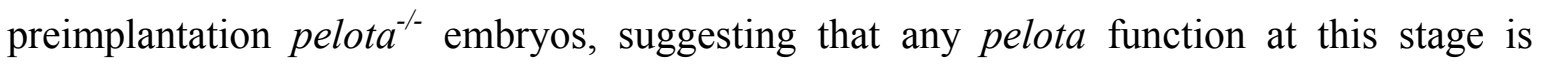
compensated for either by maternally encoded pelota or by other proteins that have similar function. The pelota ${ }^{-/}$embryos implant normally and stimulate a decidual reaction. This consistent with the observation that the embryonic cells spread and attach normally in the first few days of blastocyst culture (Fig. 3.19). 


\subsection{Mutation of the pelota gene arrests the mitotic division at $\mathrm{G} 2 / \mathrm{M}$ boundary}

In uterus, pelota null embryos die after the initiation of gastrulation (E6.5), a particularly active period of cell division characterized by very short cell cycle (as short as 2 hr) (Snow, 1977; Hogan et al., 1994). To determine cellular proliferation and viability at the early embryonic development, blastocysts were isolated from heterozygous intercrosses. Blastocysts are composed of two cell types, pluripotent cells in the inner cell mass and trophectoderm cells (review in Hogan et al., 1994; Kaufman, 1992). When control blastocysts were grown in tissue culture, cells derived from the inner cell mass (ICM) became highly proliferative and cells derived from the trophectoderm (trophoblast like cells) became relatively quiescent. In culture, while the ICM cells of pelota ${ }^{+/+}$and pelota $^{+/-}$embryos continued to expand throughout the 7-day culture period, pelota ${ }^{-/}$ICM cells failed to expand subsequent to day 4 and the embryo invariably died by day 6 in culture. In contrast, pelota $^{-/-}$trophoblast cells continued to grow in size through 7 days of culture. These results demonstrate that the death of pelota $^{-/}$cells is restricted to the rapidly

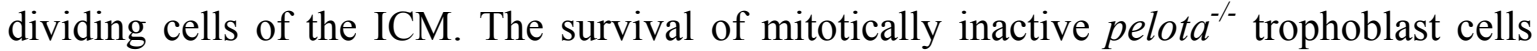
further argues that pelota is required selectively in cells undergoing mitosis. In addition, numerous attempts to generate pelota homozygous mutant ES cells were done by increasing G418 concentration. These approaches were unsuccessful.

These results from in vitro experiments directly support a generalized failure in cellular proliferation in pelota mutant. Survival of the pelota ${ }^{-/}$embryos until E6.5 rises the question, why does the failure in cellular proliferation only become apparent so late in development. One possibility is that in mice, as in Xenopus, the checkpoint does not function (is not required) in the very early embryonic cell cycles (Chen et al., 1996). A second possibility is that maternal transcripts provide sufficient pelota for early division, but the maternal store is eventually exhausted. However, several studies have shown that the vast majority of RNA in E3.5 and later embryos arises from zygotic transcription and that maternal mRNA is largely gone (Bachvarova and Deleon, 1980; Nothias et al., 1995). Exhaustion of maternal pelota mRNA therefore seems an unlikely explanation for the late onset of a phenotype. A final possibility is that the requirement of pelota only becomes critical at about the time of gastrulation, when embryos enter a period of rapid cell division (E6.5). The final possibility may explain the arrest of cell proliferation in postimplantation stage of pelota mutant embryos. 
Postimplantation lethality and failure of ICM cells to proliferate in culture were reported for knockout mice, which lack genes controlling the mitotic cell cycle. However, the cause of proliferation arrest varied among these different mutant mice. Lacking of the checkpoint protein Mad2 results in chromosome missegregation (Dobles et al., 2000). Extensive chromosomal fragmentation was observed in the ATR deficient cells (Brown and Battimore, 2000). Disruption of many genes involved in double-stranded break repair, including BRCA1, BRCA2, RAD50, RAD51 and MRE11, lead to early embryonic lethality in mice. Many of these genes have also been shown to be essential for ES cell viability and chromosomal stability (Hakem et al., 1996; Lim and Hasty, 1996; Sharan et al., 1997; Luo et al., 1999; Yamaguchi-Iwai et al., 1999).

To identify the cause of proliferative arrest in the pelota ${ }^{-/}$embryo, DNA content in embryonic cells of E7.5 was determined by CAS image analysis. This analysis indicate that $19-51 \%$ of analyzed cells in E7.5 displayed $4 n$ DNA content whereas $0-12 \%$ of analyzed cells in control embryos were found to be polyploid. These data suggest that the deficiency in pelota embryos results in cell cycle arrest at the $\mathrm{G}_{2} / \mathrm{M}$ transition.

The lethal phenotype observed in the pelota mutant embryos was unexpected because in Drosophila mitotically dividing cells deficient for pelota are viable. There are two possible explanations for this discrepancy. One is that mammalian pelota maintained the same function as Drosophila pelota, but this function is essential in mammalian cells but not in Drosophila. Another possibility is that the pelota Drosophila mutant is not a null allele. The mutation in Drosophila resulted from insertion of $\mathrm{P}$ element in the second intron of the gene (Eberhart and Wasserman, 1995).

\subsection{Pelota is localized in the centrosomes}

Subcellular localization of the pelota protein was determined by immunofluorescence microscopy of GFP-pelota transfected ES cells. GFP-fluorescence signals were found to localize to centrosomes throughout the cell cycle in ES cells, as judged by colocalization with the $\gamma$-tubulin (Fig. 3.35; 3.36; 3.36; 3.37 and 3.38). These data suggest that the pelota is associated with centrosomes during the cell cycle.

Centrosomes in normal mitotic cells facilitate the assembly of bipolar spindle and assure equal distribution of the replicated genome to each daughter cell. Moreover, this process 
provides each daughter cell with a single centrosome. The regulatory mechanism (checkpoint) that assures that centrosomes divide only once in a given cell cycle establishes a condition favouring a bipolar spindle assembly and mitotic stability. Presumably, mutations or altered expression of genes controlling centrosome duplication could abrogate the checkpoint that assures a single round of centrosome replication, resulting in cells that assemble more than the usual pair of centrosomes. Mutational inactivation of the tumor suppressor gene BRCA 1 (Xu et al., 1999) and P53 (Fukasawa et al., 1996), which are also associated with the centrosomes, was reported to alter a checkpoint and initiate multiple round of centrosome replication within a single cell cycle. Isolated fibroblasts from these mutant mice contain multiple centrosomes, which lead to unequal chromosome segregation and aneuploidy. More recently, supernumerary centrosomes have been reported in a variety of different tumor cells in vitro and in vivo (Lingle et al., 1998; Pihan et al., 1998; Ghadimi et al., 2000). During the meiotic division in Drosophila pelota mutant, spindle apparatus is not formed. Therefore, it is very important to address the question, whether the inactivation or overexpression of pelota gene affects the centrosome duplication. This can be addressed by establishment of pelota $^{-/}$cell lines from conditional knockout mice and from transgenic mice overexpressing pelota gene or from generated stabile transfected cell lines that express the antisense pelota-transcript.

Centrosome contains a pair of centrioles surrounded by an electron-dense pericentriolar matrix, from which a polarized array of cytoplasmic microtubules is assembled. Cells lacking centrioles can still form bipolar spindles (review in Marshall, 2001). Recent reports reveal that the centrioles regulate the orientation of the bipolar spindle in the dividing cells. In the unicellular green alga Chlamydomonas, mutant bald 2 has severe defects in centriole structure. Analysis of cell division in bald2 mutant strains in which spindle assembly and mitosis proceed normally, the spindle was often misorientated with respect to the cleavage furrow, resulting in cytokinesis errors (Goodenough and StClair, 1975; Ehler et al., 1995). Drosophila mutant lacking centriole-associated protein fail to develop and show dramatic defect in cell division (Vaizel-Ohayon and Schejter, 1999; Megraw et al., 2001). Mouse embryo cells complete up to 16 cell divisions without centrioles and then generate new centrioles de novo in subsequent cell divisions (Szollosi, 1972; Calarco, 2000). If the pelota is one of structural proteins in the centrioles, one can speculate that the lack of pelota affects the centriole formation in embryonic cells and mediates the arrest of mitotic 
division. This can explain why the mitotic divisions is only affected after E7.5 in pelota deficient embryos. 


\section{SUMMARY}

Expression and function of the pelota gene has originally been characterized in Drosophila. A loss-of-function mutation in Drosophila pelota was found to result in male infertility. Spermatogonia and spermatocytes are produced in mutant flies but the cell cycle of the first meiotic division is arrested during the $\mathrm{G}_{2} / \mathrm{M}$ transition.

In the present work, the expression pattern and physiological function of the mouse pelota gene was studied.

The expression of the pelota gene in different mouse tissues was analysed by Northern blot. A $1.6 \mathrm{~kb}$ pelota transcript was detected in the RNA of all studied tissues. An additional $2.1 \mathrm{~kb}$ pelota transcript was observed in RNA of the spleen. To investigate the expression of the pelota gene during prenatal development, RNA was extracted from the posterior part of 9.5 to $17.5 \mathrm{dpc}$. embryos and analysed for the presence of pelota transcript by RT-PCR. Pelota transcripts were detected in all studied embryos. To evaluate the expression of the pelota gene during testicular development, Northern blot with RNA extracted from testes of 5- to 60 -day old mice was performed. The results of Northern blot hybridisation revealed that the pelota gene is expressed throughout postnatal testis development. Further Northern blot analyses with testicular RNA isolated from mutant mice indicate that the expression of the pelota gene is not restricted to spermatogenic cells of the testis.

To elucidate the potential role of the mammalian pelota gene, the gene was deleted in mice through homologous recombination. Both male and female mice heterozygous for pelota deletion were phenotypically normal and fertile. Heterozygous animals were intercrossed and the offspring were genotyped by PCR analysis. No pelota ${ }^{-/}$animals were detected in the $F_{2}$ generation. These results indicate that pelota deficiency results in embryonic death. To assess the consequence of the pelota mutation for embryonic development, embryos were collected from heterozygous intercrosses at different days of prenatal development. PCR analysis of postimplantation embryos dissected from the deciduas at embryonic days (E) 8.5, 9.5 and 10.5 showed that none of studied embryos was pelota ${ }^{-/-}$, while analysis of preimplantation embryos at E2.5 and 3.5 revealed the presence of pelota ${ }^{-/-}$embryos in the expected ratio as defined by Mendelian distribution. These results demonstrate that pelota '- embryos die between E3.5 and E8.5. 
To determine the cause and time of embryonic lethality, histological analysis of deciduas at embryonic days $6.5,7.5,8.5$ and 9.5 were performed. The results of these studies revealed that the development of the pelota deficient embryos up to E6.5 appears normal but slows down at the E7.5. After E9.5, no viable pelota ${ }^{-/}$were observed. The fact that differentiation of the three germ layers is initiated in the pelota $a^{-/}$embryos suggests that the developmental arrest is not due to lack of differentiation, but rather results from a proliferation defect. To directly determine the growth capability of mutant pelota ${ }^{-/}$ embryos, E3.5 blastocyts from heterozygous intercrosses were collected and cultured individually for 7 days and then genotyped by PCR. During the first 4 days in culture, the inner cell mass (ICM) of pelota ${ }^{-/}$blastocysts was indistinguishable from that of pelota ${ }^{+/+}$

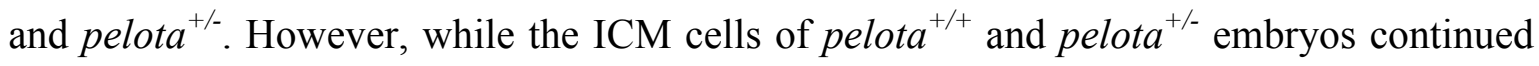
to expand throughout the 7-day, pelota $^{-/-}$ICM cells failed to expand subsequent to day 4 . In contrast, pelota ${ }^{-/-}$trophoblast gaint cells (TGC) continued to grow in size through 7 days of culture. The survival of mitotically inactive pelota $^{-/}$trophoblast gaint cells and the death of mitotically active inner cell mass of pelota ${ }^{-/}$blastocysts support our hypothesis that pelota is required during mitosis.

To address the question whether the mitotic cell cycle is arrested in the pelota $^{-/}$embryos, DNA contents in embryonic cells of E7.5 was determined with CAS image system. Results of these studies suggest that the deficiency of pelota results in a cell cycle arrest at the G2/M transition.

To determine the subcellular localization of pelota protein, embryonic stem cells (ES) were transfected with green fluorescent protein (GFP)-targeted pelota and expressing clones were selected. Microscopic examination of the transfected ES cells showed that GFPfluorescence signal was localized at the centrosomes. Immunostaining of the GFP-pelota transfected ES cells with monoclonal anti $\gamma$-tubulin demonstrated that the $\gamma$-tubulin, a marker for centrosomes, colocalized exactly with the GFP-fluorescence signal in interphase, prophase and metaphase. These results indicate that pelota protein is associated with the centrosome. 


\section{REFERENCES}

BACHVAROVA, R. and DE LEON, V. (1980). Polyadenylated RNA of mouse ova and loss of maternal RNA in early development. Dev. Biol., 74:1-8.

BOBINNEC, Y., KHODJAKOV, A., MIR L.M., RIEDER C.L., EDDE, B. and BORNENS, M. (1998). Centriole disassembly in vivo and its effect on centrosome structure and function in vertebrate cells. J. Cell Biol., 143: 1575-89

BRINKLEY, B.R. and GOEPFERT, T.M. (1998). Supernumerary centrosomes and cancer: Boveri's hypothesis resurrected. Cell Motil. Cytoskeleton, 41: 281-8.

BROWN, J. E. and BALTIMORE, D. (2000). ATR distruption leads to chromosomal fragmentation and early embryonic lethality. Genes \& Dev., 14: 397-402.

BULT, C.J., WHITE, O., OLSEN, G.J., ZHOU, L., FLEISCHMANN, R.D., SUTTON, G.G., BLAKE, J.A., FITZGERALD, L.M., CLAYTON, R.A., GOCAYNE, J.D., KERLAVAGE, A.R., DOUGHERTY, B.A., TOMB, J.F., ADAMS, M.D., REICH, C.I., OVERBEEK, R., KIRKNESS, E.F., WEINSTOCK, K.G., MERRICK, J.M., GLODEK, A., SCOTT, J.L., GEOGHAGEN, N.S. and VENTER, J.C. (1996). Complete genome sequence of the methanogenic archaeon, Methanococcus jannaschii. Science., 273: 1058-73.

BUSCH, S.J. and SASSONE-CORSI, P. (1990). Dimers, leucine zippers and DNA-binding domains. Trends Genet., 6: 36-40.

CAHILL, D.P., LENGAUER, C., YU, J., RIGGINS, G.J., WILLSON, J.K., MARKOWITZ, S.D., KINZLER, K.W. and VOGELSTEIN, B. (1998). Mutations of mitotic checkpoint genes in human cancers. Nature, 392: 300-303. 
CALARCO, P. G. (2000). Centrosome precursors in the acentriolar mouse oocyte. Microsc. Res. Tech., 49: 428-34.

CARROLl, P.E., OKUDA, M., HORN, H.F., BIDDINGER, P., STARNBROOK, P.J., GLEICH, L.L., LI, Y.Q., TARAPORE, P. and FUKASAWA, K., (1999). Centrosome hyperamplification in human cancer: chromosome instability induced by p53 mutation and/or Mdm2 overexpression. Oncogene, 18: 1935-44.

CASTRILlON, D.H., GONCZY, P., ALEXANDER, S., RAWSON, R., EBERHART, C.G., VISWANATHAN, S., DINARDO, S. and WASSERMAN, S.A. (1993). Toward a molecular genetic analysis of spermatogenesis in Drosophila melanogaster: characterization of malesterile mutants generated by single P element mutagenesis. Genetics, 135: 489-505.

CHEN, C.Y., OLINER, J.D., ZHAN, Q., FORNACE, A..J. .JR., VGELSTEIN, B. and KASTAN, M.B. (1994). Interactions between p53 and MDM2 in a mammalian cell cycle checkpoint pathway. Proc. Natl. Acad. Sci. USA, 91: 2684-8.

CHEN, R.H., SHEVCHENKO, A., MANN, M. and MURRAY, A.W. (1998). Spindle checkpoint protein Xmad1 recruits Xmad2 to unattached kinetochores. J. Cell Biol., 143: 283-95.

CHEN, R.H., WATERS, J.C., SALMON, E.D. and MURRAY, A.W. (1996). Association of spindle assembly checkpoint component XMAD2 with unattached kinetochores. Science, 274: 242-6.

DAVIS, L. and ENGEBRECHT, J. (1998). Yeast dom34 mutants are defective in multiple developmental pathways and exhibit decreased levels of polyribosomes. Genetics 149: $45-56$. 
DOBLES, M., LIBERAL, V., SCOTT, M.L., BENEZRA, R. and SORGER, P.K. (2000). Chromosome missegregation and apoptosis in mice lacking the mitotic checkpoint protein Mad2. Cell, 101: 635-45.

EBERHART, C.G. and WASSERMAN, S.A. (1995). The pelota locus encodes a protein required for meiotic cell division : an analysis of G2/M arrest in Drosophila spermatogenesis. Development, 121: 3477-86.

EHLER, L. L., HOLMES, J. A. and DUTCHER, S. K. (1995). Loss of spatial control of the mitotic spindle apparatus in a Chlamydomonas reinhardtii mutant strain lacking basal bodies. Genetics, 141: 945-60.

ELLEDGE, S.J. (1996). Assessing p53 status in breast cancer prognosis: where should you put the thermometer if you think your p53 is sick. J Natl Cancer Inst., 88: 141-3.

EVANS, M.J. and KAUFMAN, M.H. (1981). Establishment in culture of pluripotential cells from mouse embryos. Nature, 292: 154-6.

FEINBERG, A.P. and VOGELSTEIN, B. (1989). A technique for radiolabeling DNA restriction endonuclease fragments to high specific activity. Anal. Biochem., 123: 6-13.

FROLOVA, L., LE, GOFF, X., RASMUSSEN, H.H., CHEPEREGIN, S., DRUGEON, G., KRESS, M., ARMAN, I., HAENNI, A.L., CELIS, J.E., PHILIPPE, M. and et al. (1994). A highly conserved eukaryotic protein family possessing properties of polypeptide chain release factor. Nature, 372: 701-3.

FUKASAWA, K., CHOI, T., KURIYAMA, R., RULONG, S. and VANDE WOUDE G.F. (1996). Abnormal centrosome amplification in the absence of p53. Science, 271:1744-7. 
GHADIMI, B. M., SACKETT, D. L., DIFILIPPANTONIO, M. J., SCHROCK, E., NEUMANN, T., JAUHO, A., AUER, G. and RIED, T. (2000). Centrosome amplification and instability occurs exclusively in aneuploid, but not in diploid colorectal cancer cell lines, and correlates with numerical chromosomal aberrations. Genes Chromosomes Cancer, 27: $183-90$

GOODENOUGH, U. W. and STCLAIR, H. S. (1975). BALD-2: a mutation affecting the formation of doublet and triplet sets of microtubules in Chlamydomonas reinhardtii. J. Cell Biol.,66: 480-91.

GUETH-HOLlONET, C., ANTONY, C., AGHION, J., SANATA-MARIA, A., LAJOIEMAZENC, I., WRIGHT, M. and MARO, B. (1993). $\gamma$-Tubulin is present in a centriolar MTOCs during mouse development. J. Cell Sci., 105: 157-166.

HAKEM, R., DE LA POMPA, J. L., SIRARD, C., MO, R., WOO, M., HAKEM, A., WAKEHAM, A., POTTER, J., REITMAIR, A., BILliA, F., FIRPO, E., HUI, C. C., ROBERTS, J., ROSSANT, J. and MAK, T.W. (1996). The tumor suppressor gene Brca1 is required for embryonic cellular proliferation in the mouse. Cell, 85: 1009-23.

HANES, J., FREUDENSTEIN, J., RAPP, G. and SCHEIT, K.H. (1992). Construction of a plasmid containing the complete coding region of human elongation factor 2. Biol. Chem. Hoppe Seyler, 373: 201-4.

HARDWICK, K.G. (1998). The spindle checkpoint.Trends. Genetics, 14: 1-4.

HIGGINS, D.G., BLEASBY, A.J. and FUCHS, R. (1992). CLUSTAL V: improved software for multiple sequence alignment. CABIOS, 8: 189-191. 
HINCHCLIFFE, E.H., MILlER, F.J., CHAM, M., KHODJAKOV, A. and SLUDER, G. (2001). Requirement of a centrosomal activity for cell cycle progression through G1 into S phase. Science, 291: 1547-50.

HOGAN, B., BEDDINGTON, R., CONSTANTINI, F. and LACY, E. (1994). Manipulating the mouse embryo. New York: Cold Spring Harbor Press, 4: 1-88.

HUNT, A.W. and MURRAY, T.I.(1993). In the cell cycle, P. 175. New York: W. H. Freeman.

KASTAN, M.B., ZHAN, Q, EL-DEIRY, W.S., CARRIER, F, JACKS, T, WALSH, W.V., PLUNKETT, B.S., VOGELSTEIN, B. and FORNACE, A.J. JR. (1992). A mammalian cell cycle checkpoint pathway utilizing p53 and GADD45 is defective in ataxia-telangiectasia. Cell, 71: 587-97.

KAUFMAN, M. H. (1992). The atlas of mouse development, US. Ed. Academic Press, Inc., San Diego, Calif.

KAUFMAN, M.H. (1992). Postcranial morphological features of homozygous tetraploid mouse embryos. J. Anat., 180: 521-34

KHODJAKOV, A. and RIEDER C.L. (2001). Centrosomes enhance the fidelity of cytokinesis in vertebrates and are required for cell cycle progression. J. Cell Biol., 153: 237-42.

KINZLER, K.W. and VOGELSTEIN, B. (1996). Lessons from hereditary colorectal cancer. Cell, 87: 159-70. 
KUERBITZ, S.J., PLUNKETT, B.S., WALSH, W.V. and KASTAN, M.B. (1992). Wild-type p53 is a cell cycle checkpoint determinant following irradiation. Proc. Natl. Acad. Sci. USA, 89: $7491-5$.

LAIRD, P.W., ZIJDERVELD, A., LINDERS, K., RUDNICKI, M.A., JAENISCH, R. and BERNS, A. (1991). Simplified mammalian DNA isolation procedure. Nucleic Acids Res., 19: 4239.

LENGAUER, C., KINZLER, K.W. and VOGELSTEIN, B. (1997). Genetic instability in colorectal cancers. Nature, 386: 623-7

LIM, D. S. and HASTY, P. (1996). A mutation in mouse rad51 results in an early embryonic lethal that is suppressed by a mutation in p53. Mol. Cell Biol., 16: 7133-43.

LINGLE, W.L., LUTZ, W.H., INGLE, J.N., MAIHLE, N.J. and SALISBURY, J.L. (1998). Centrosome hypertrophy in human breast tumors : implications for genomic stability and cell polarity. Proc. Natl. Acad. Sci. USA, 95: 2950-5

LIVINGSTON, D.M., KAELIN, W., CHITTENDEN, T. and QIN, X. (1992). Structural and functional contributions to the G1 blocking action of the retinoblastoma protein. Br. J. Cancer, 68:264-8.

LUO, G., YAO, M. S., BENDER, C. F., MILlS, M., BLADL, A.R., BRADLEY, A. and PETRINI, J. H. (1999). Disruption of mRad50 causes embryonic stem cell lethality, abnormal embryonic development, and sensitivity to ionizing radiation. Proc. Natl. Acad. Sci., USA $22 ; 96$. 
MANSOUR, S.L., THOMAS, K.R. and CAPECCHI M.R. (1998). Disruption of the protooncogene int-2 in mouse embryo-derived stem cells: a general strategy for targeting mutations to non-selectable genes. Nature, 336: 348-52.

MARSHALL, W. F. (2001). Rethinking centrosome function. Trends Cell Biol., 11: 193.

MARTIN, G.R. (1981). Isolation of a pluripotent cell line from early mouse embryos cultured in medium conditioned by teratocarcinoma stem cells. Proc. Natl. Acad. Sci. USA, 78: 763 4-8.

MEGRAW, T. L., KAO, L. R. and KAUFMAN, T. C. (2001). Zygotic development without functional mitotic centrosomes. Curr. Biol., 11: 116-20.

MORITZ, M., BRAUNFELD, M.B., SEDAT, J.W., ALBERTS, B. and AGARD, D.A. (1995). Microtubule nucleation by gamma-tubulin-containing rings in the centrosome.Nature, 378: $638-40$.

MURRAY, A.W. (1992). Creative blocks cell cycle checkpoint and feedback controls. Nature, 359: 599-604.

NOMOTO, S., HARUKI, N., TAKAHASHI, T., MASUDA, A., KOSHIKAWA, T., TAKAHASHI, T., FUJII, Y., OSADA, H. and TAKAHASHI, T. (1999). Search for in vivo somatic mutations in the mitotic checkpoint gene, hMAD1, in human lung cancers. Oncogene, 18: $7180-3$

NOTHIAS, F., BOYNE, L., MURRAY, M., TESSLER, A. and FISCHER, I. (1995). The expression and distribution of tau proteins and messenger RNA in rat dorsal root ganglion neurons during development and regeneration. Neuroscience, 66: 707-19. 
PIHAN, G.A, PUROHIT, A., WALLACE, J., KNECHT, H., WADA, B., QUESENBERRY, P. and DOXSEY, S.J. (1998). Centrosome defects and genetic instability in malignant tumors. Cancer Res., 58: 3974-85.

PINES, J. (1993). Cyclins and their associated cyclin-dependent kinases in the human cell cycle. Biochem. Soc. Trans., 21: 921-5.

RAGAN, M.A., LOGSDON, J.M. JR, SENSEN, C.W., CHARLEBOIS, R.L. and DOOLITTLE, W.F. (1996). An archaebacterial homolog of pelota, a meiotic cell division protein in eukaryotes. FEMS Microbiol Lett., 144: 151-5.

RINKENBERGER, J.L., CROSS, J.C. and WERB, Z. (1997). Molecular genetics of implantation in the mouse. Dev. Genet., 21: 6-20.

RUDNER, A.D. and MURRAY, A.W. (1996). The spindle assembly checkpoint. Cell Biol., 8: 773-80.

RUGH, R. (1990). The mouse: Its reproducton and development. Oxford University Press, New York: S. 282-295.

SANDELL, L.L. and ZAKIAN, V.A. (1993). Loss of a yeast telomere: arrest, recovery, and chromosome loss. Cell., 75: 729-39.

SCHATTEN, G. (1994). The centrosome and its mode of inheritance: the reduction of the centrosome during gametogenesis and its restoration during fertilization. Dev. Biol., 165: 299-335. 
SCHATTEN, G., SIMERLY, C. and SCHATTEN, H. (1991). Maternal inheritance of centrosomes in mammals? Studies on parthenogenesis and polyspermy in mice. Proc. Natl. Acad. Sci. USA., 88: 6785-9.

SCHATTEN, H., SCHATTEN, G., MAZIA, D., BALCZON, R. and SIMERLY, C. (1986). Behaviour of centrosomes during fertilization and cell division in mouse oocytes and in sea urchin eggs. Proc. Natl. Acad. Sci. U S A., 83: 105-9.

SHAMSADIN, R., ADHAM, I.M., VON BEUST, G. and ENGEL, W. (2000). Molecular cloning expression and chromosome location of the human pelota gene PELO. Cytogenet. Cell Genet., 90: 75-8.

SHAMSADIN, R., JANTSAN, K., ADHAM, I. and ENGEL, W. (2001). Cloning organization, chromosomal localization and expression analysis of the mouse Prkag 1 gene. Cytogenet. Cell Genet., 92: 134-8.

SHARAN, S. K., MORIMATSU, M., ALBRECHT, U., LIM, D. S., REGEL, E., DINH, C., SANDS, A., EICHELE, G., HASTY, P. and BRADLEY, A. (1997). Embryonic lethality and radiation hypersensitivity mediated by Rad51 in mice lacking Brca2. Nature, 386: 804-10.

SNOW, M. (1977). Gastrulation in the mouse: growth and regionalization of the epiblast. J. Embryol. Exp. Morphol., 42: 293-303.

SOUTHERN, E.M. (1975). Detection of specific sequences among DNA fragments separated by gel electrophoresis. J. Mol. Biol., 98:138-149.

SZOLLOSI, D., CALARCO, P. and DONAHUE, R.P. (1972). Absence of centrioles in the first and second meiotic spindles of mouse oocytes. J. Cell Sci., 1: 521-41.. 
TAKAI, H., TOMINAGA, K., MOTOYAMA, N., MINAMISHIMA, A. Y., NAGAHAMA, H., TSUKIYAMA, T., IKEDA, K., NAKAYAMA, K., NAKANISHI, M. and NAKAYAMA, K. (2000). Aberrant cell cycle checkpoint function and early embryonic death in Chk1-/- mice. Genes \& Dev., 14: 1439-1447.

TAYLOR, S.S., HA, E. and MCKEON, F. (1998). The human homologue of Bub3 is required for kinetochore localization of Bub1 and a Mad3/Bub1-related protein kinase. J. Cell Biol., 142: 1-11.

TOURNIER, F., JOLY, A. and BORNENS, M. (1994). Production of partial blastulas by parthenogenesis in Xenopus. Acad. Sci. III, 317: 405-10.

VAIZEL-OHAYO, D., SCHEJTER, E. D. (1999). Mutations in centrosomin reveal requirements for centrosomal function during early Drosophila embryogenesis. Curr. Biol., 10: 889-898.

VANDRE, D.D. and BORISY, G.G. (1989). Anaphase onset and dephosphorylation of mitotic phosphoproteins occur concomitantly. J. Cell Sci., 94: 245-58.

WEINERT, T.A., KISER, G.L. and HARTWELL, L.H. (1994). Mitotic checkpoint genes in building yeast and the dependence of mitosis on DNA replication and repair. Genes Dev., 8: $652-65$

WELSH, A. O. (1993). Uterine cell death during implantation and early placentation. Microsc. Res. Tech., 25: 223-45. 
XU, Y. and BALTIMORE, D. (1996). Dual roles of ATM in cellular response to radiation and in cell growth control. Genes \& Dev., 10: 2401-2410.

XU, X., WEAVER, Z., LINKE, S.P., LI, C., GOTAY, J., WANG, X.W., HARRIS, C.C., RIED, T. and DENG, C.X. (1999). Centrosome amplification and a defective G2-M cell cycle checkpoint induce genetic instability in BRCA1 exon 11 isoform-deficient cells. Mol. Cell., 3: 389-95.

YAMAGUCHI-IWAI, Y., SONODA, E., SASAKI, M. S., MORRISON, C., HARAGUCHI, T., HIRAOKA, Y., YAMASHITA, M. Y., YAGI, T., TAKATA, M., PRICE, C. et al. (1999). Mre11 is essential for the maintenance of chromosomal DNA in vertebrate cells. EMBO J., 18: 6619-6629.

ZHENG, Y., WONG, M.L., ALBERTS, B. and MITCHHISON, T. (1995). Nucleation of microtubule assembly by a gamma-tubulin-containing ring complex. Nature, 378: 578-83. 


\section{ACKNOWLEDGEMENT}

I would like to express my gratitude to Prof. Dr. W. Engel for giving me the chance to perform the Ph.D. studies in 'Institut für Humangenetik', his acceptance to be my Coreferee in this work and for his support for the conferences I attended.

I also wish to express my thanks to Prof. Dr. P. Glodek for his acceptance to be my scientific supervisior and for his readiness for this work.

I thank sincerely and deeply Dr. I. M. Adham for giving me the chance to learn and make the Ph.D work in the laboratory under his charge. I m very thankful for his help and understanding about all the events that happened throughout this study.

I thank Dr. M. Korabiowska, Dr. S. Hoyer-Fender and Dr. M. Kämper for their technical support in some experiments performed in this work..

I thank all co-workers in the "Institut für Humangenetik', Their help was essential for me to finish this work.

I thank Arabic Republic Egypt for its financial support to my Ph.D study in Germany.

I thank my family for everything they have done for me. 


\section{CURRICULUM VITAE}

Name: $\quad$ Mahmoud Ahmed Abd El-Hafiez Sallam

Date of Birth: $\quad 20 / 8 / 1964$

Place of Birth: $\quad$ Egypt

Citizenship: $\quad$ Egyptian

Marital Status: $\quad$ Married

1973-1979: $\quad$ Primary School

1979-1982: $\quad$ Secondary School

1982-1987: Department of Genetics, Faculty of Agriculture, Ain Shams University.

1987: $\quad$ B.Sc. Degree in Agricultural Sciences with Major in Genetics

1993: $\quad$ M. Sc. In Agriculture (Genetics)

1996-2001: Ph.D study in Institut für Humangenetik, Georg-AugustUniversität, Göttingen, Germany 